Universidad Nacional de La Plata

Facultad de Bellas Artes

Secretaría de Posgrado

\title{
LA INSTALACIÓN COMO DISPOSITIVO ESCÉNICO Y EL NUEVO ROL DEL ESPECTADOR
}

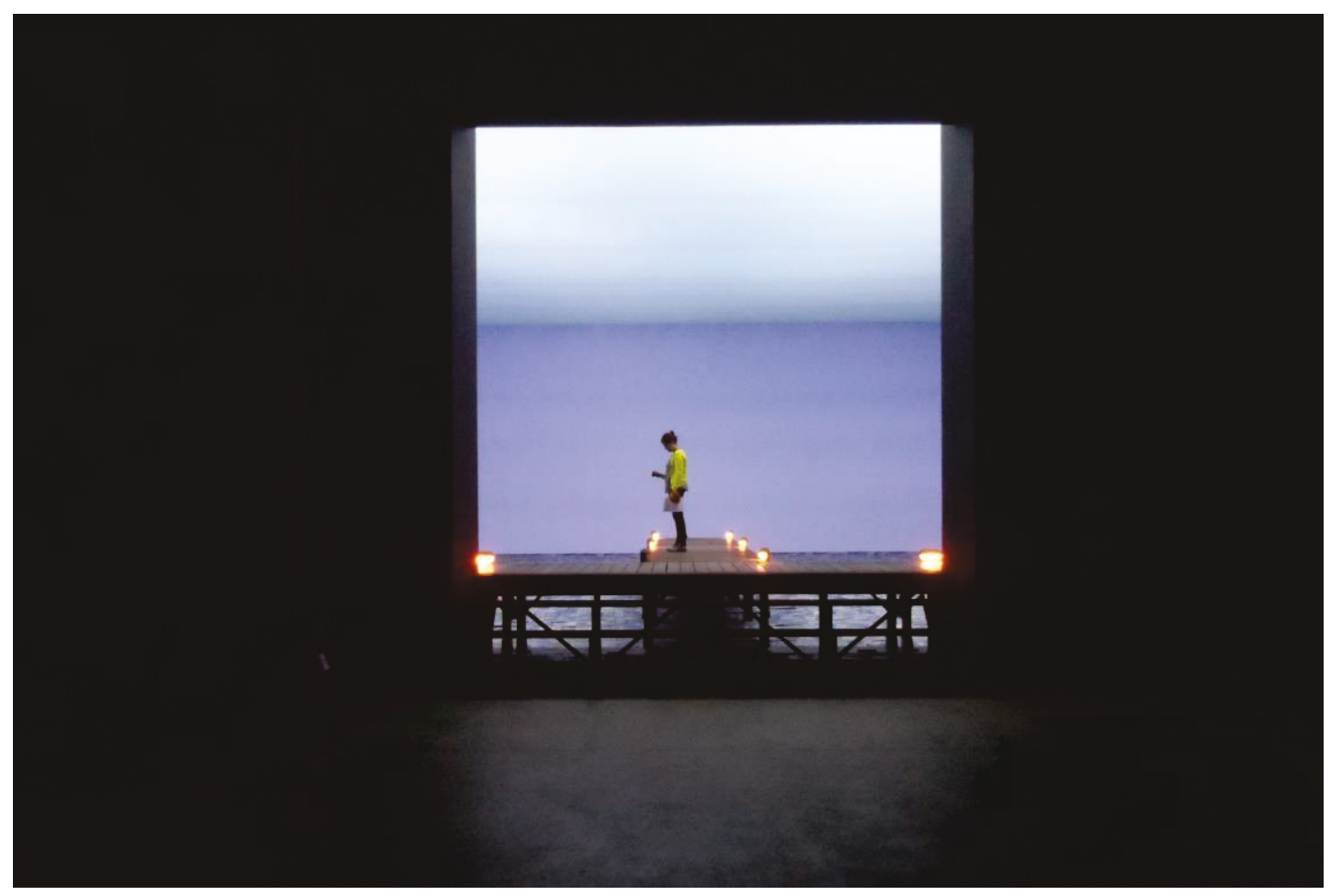

María Silvina Valesini

Tesis para optar por el grado de Magister en Estética y Teoría de las Artes Directora: Lic. Silvia Susana García. UNLP

La Plata, diciembre de 2014 
A mi madre y a la memoria de mi padre. Gracias por creer siempre en mí. 


\section{INDICE GENERAL}

Agradecimientos

INTRODUCCIÓN

Motivaciones y propósitos

Aspectos metodológicos

Mapa del documento

\section{CAPÍTULO 1 - (in) Definiciones.}

1.1. El problema de la denominación $\quad$............................................. 16

1.2. Espacio expositivo, arte, escultura o qué? ……………………..... 24

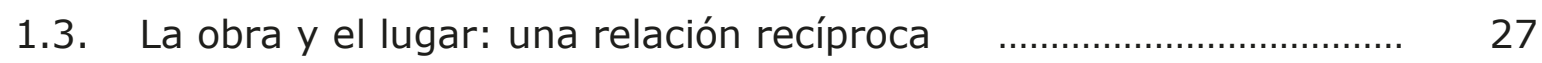

1.4. La instalación como dispositivo …………………………......... 33

1.5. Apuntes para una definición descentrada $\quad$................................... 34

\section{CAPÍtULO 2 - Acerca de los orígenes reconocidos: Del minimalismo} a la instalación.

2.1. En torno al surgimiento de categorías conceptuales para la comprensión y análisis de las instalaciones

2.2. Michael Fried: La condena de lo teatral

2.3. Hibridación y contingencia

2.4. La contradicción entre especificidad y presencia

\section{CAPÍTULO 3 - Poéticas en cruce. La pregunta por lo teatral.}

3.1. Teatralidad y artes visuales: una frontera imprecisa $\quad$............... 52

3.2. El teatro como acontecimiento ............................................. 54

3.3. Territorios mixtos: Espacios del teatro - espacios de la instalación 58

3.4. El cuerpo en acto: representación y performatividad $\quad \ldots \ldots \ldots \ldots . . . . .62$

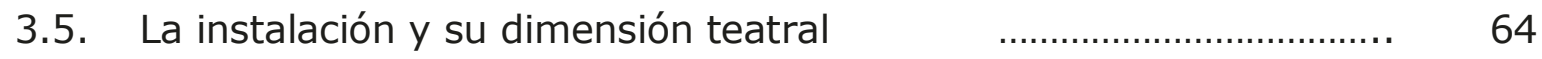




\section{CAPÍTULO 4 - La experiencia del arte y la construcción de un nuevo}

espectador.

4.1. Un arte de la presencia: el espectador corporeizado $\quad$................ 70

4.1.1. Acción y participación: La habitación del borramiento, de Yayoi Kusama 72

4.2. Una aproximación a la mirada fenomenológica $\quad$.......................... 76

4.3. Coordenadas móviles: tiempo/ espacio/ espectador en la obra transitable

4.3.1. Habitar y experimentar. Edificio, de Leandro Erlich ………………...... 80

4.3.2. De la idea del artista a la voluntad del espectador: Marulho (el murmullo del mar), de Cildo Meireles

4.3.3. Narración en tres tiempos y un espacio: Desvío al rojo, de Cildo Meireles 86

4.3.4. El reconocimiento de la propia mirada: el espectador cómplice. Red room/Parents (La habitación del padre), de Louise Bourgeois ...... 92

4.4. El espectador / ¿actor? …………………….................................. 97

4.4.1. Cuando la mirada del otro construye al actor: Migrantes, de Christian Boltanski ............................................................................. 99

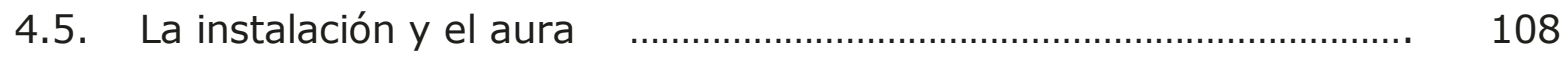

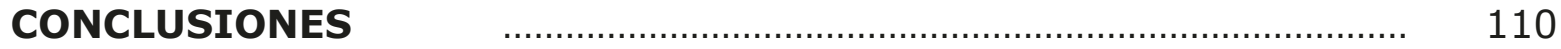

Bibliografía citada y/o consultada ………......................................... 115 


\section{AGRADECIMIENTOS}

A la Universidad de La Plata, que hizo posible a través de su Programa de Becas para la formación de Posgrado la escritura de esta Tesis.

A mi directora, Silvia García, por su infinita generosidad académica y humana.

A mi colega y amiga Guillermina Valent, por enriquecer el proceso de este trabajo con sus preguntas agudas, su dedicada lectura y su buen humor. Los jueves del conocimiento dan sus primeros frutos, pero esto es sólo el comienzo...

A mis compañeras de trabajo y amigas, Jorgelina y Karen, que en este tiempo redoblaron su tarea para alivianar la mía.

A Gustavo, que acompañó con profundo entusiasmo el relevamiento de las obras, y supo resistir los embates de la búsqueda bibliográfica y los meses de escritura.

A mi familia y a mis amigos, que soportaron mis ausencias y postergaciones en nombre de este proyecto. 


\section{INTRODUCCIÓN}

En octubre de 2006 el Museo Nacional de Bellas Artes exhibió la muestra retrospectiva de Renata Schussheim, titulada Epifanía. Exquisitamente presentada bajo la modalidad de caja negra, la obra transformó la sala de exposiciones temporarias con deliciosas y siniestras criaturas que articulaban una experiencia impactante y conmovedora.

Si bien la muestra como totalidad respondía a los parámetros habitualmente atribuidos a la práctica de la instalación, la artista desplegaba muy especialmente su saber hacer de escenógrafa a través de un repertorio de recursos visuales, lumínicos y sonoros que cargaban al espacio y a sus habitantes de latencias teatrales evidentes. Había especialmente dos obras en las que era imposible no detener el tiempo y la mirada: "El bosque", donde habitaba una mujer pájaro, frágil y etérea, suspendida entre veladuras de tul; y "La sirena" (Figura 1) a la que sólo se podía ver de espalda, con una larga cabellera rubia que ondeaba al viento, contemplando melancólicamente desde la escollera de un barco un mar de vodevil, un mar - deliberadamente - de cartón pintado.

El público, involucrado en una contemplación activa, adoptaba los más diversos comportamientos ante ella. La propia artista señaló al respecto

Fue muy fuerte y muy extraño lo que pasó con esa sirena: había gente que iba a meditar. Yo llegaba y los veía sentados en el suelo con los ojos cerrados, como algo mítico. Sabía que era una imagen muy fuerte por esa doble mirada, de mirar a alguien que mira a otra cosa, pero me daba mucha timidez que me preguntaran sobre la obra, así que me encerraba en un cuartito (Schussheim, 2006)

Asimismo, una reseña de la exposición señalaba que 
Ingresar a la muestra era cruzar el espejo de Alicia y quedar atrapado en un país de maravillas, en otra geografía, en un mundo otro, lejos de la realidad por la que uno había andado minutos antes, la Avenida del Libertador y los verdes de La Recoleta con sus gentes (...) Cruzar un espejo, "abrir la puerta para ir a jugar" y participar de una extraña ceremonia o de un banquete pantagruélico (Mateo, 2006)

Todavía recuerdo el sonido real de ese mar falso. Y que algo me impidió cruzar la sala y acercarme a la Sirena. Un temor reverencial, tal vez temor de molestarla, o de romper el encantamiento.

Una de las firmantes refirió en el libro de visitas que La Sirena se dio vuelta y caminó...

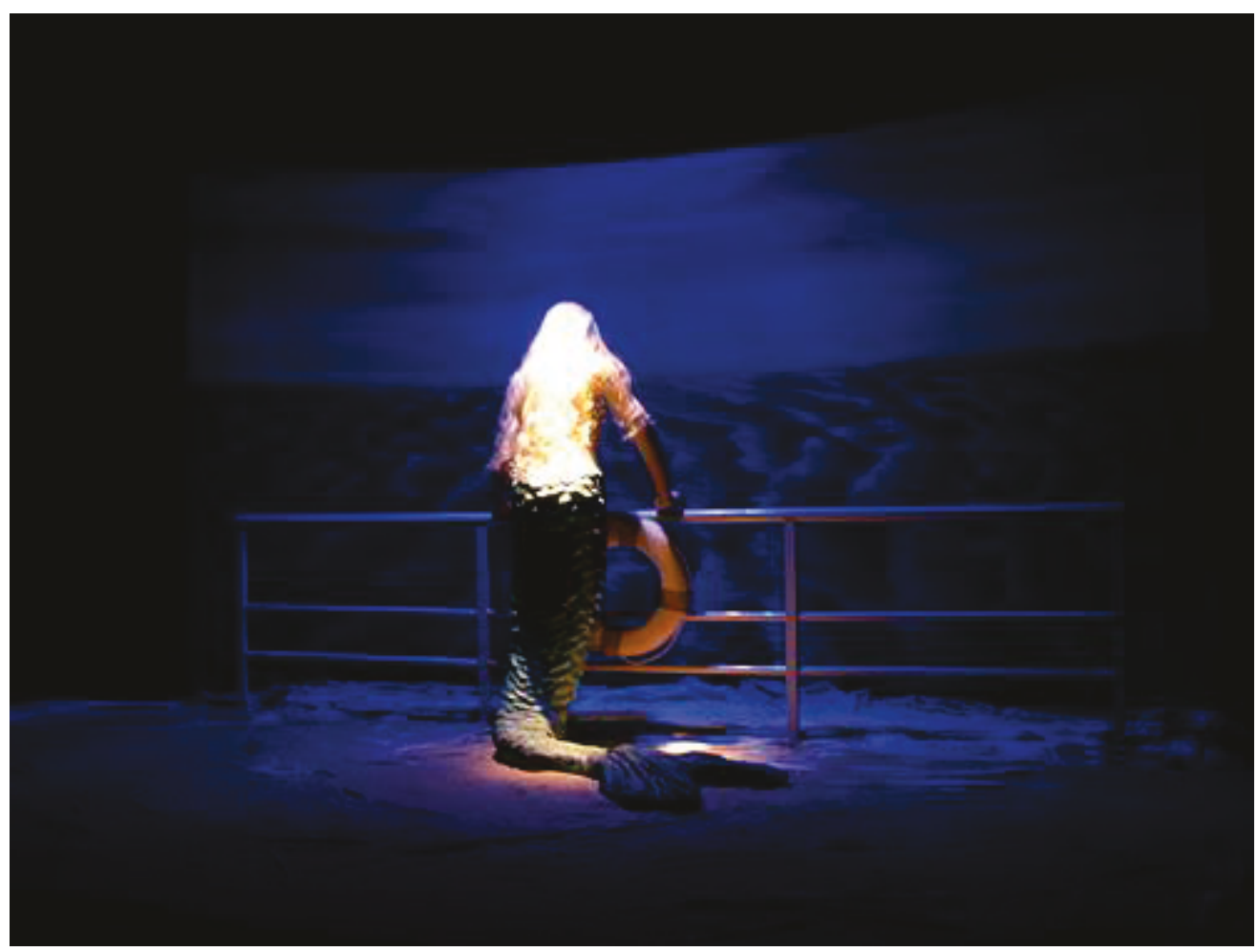

Figura 1: Vista de la instalación La Sirena, de Renata Schussheim en el Museo Nacional de Bellas Artes. 2006. 


\subsection{Motivaciones y propósitos}

El impacto del encuentro con la Sirena de Renata Schussheim ocupa un lugar central entre las motivaciones que dieron origen a este trabajo, y dirigieron mi atención sobre la instalación como concepto fundamental para entender el arte de la última mitad del siglo XX en adelante.

Al mismo tiempo - o tal vez como producto del nuevo direccionamiento de mi interés hacia el tema - dio la impresión de que "todo el arte se hubiera convertido de pronto en instalación" (Larrañaga, 2001: 7): los museos y espacios de circulación artística en general se llenaron de obras de muy diverso tenor que incluían en su definición el término; las asignaturas de la carrera de Artes Plásticas de la Facultad de Bellas Artes de la UNLP que trabajaban a partir de propuestas espaciales tridimensionales (por entonces Escultura, Escenografía y Taller Interdisciplinario), también vieron surgir en los trabajos de los últimos años una marcada tendencia hacia este tipo de producciones. Tendencia que se fue multiplicando, hasta alcanzar a las disciplinas tradicionalmente bidimensionales y extenderse incluso a las producciones de alumnos de los primeros años.

En algunos casos las cátedras se fueron adaptando a esta tendencia en sus propuestas curriculares $y$ en otros simplemente se abrieron a su aparición espontánea. Parecía que toda producción que quisiera presentarse como transgresora y contemporánea debía suscribir a la categoría de Instalación, a pesar de su momentánea indefinición. Su tendencia evidente a la superación de géneros y técnicas, su porosidad y permeabilidad fueron causales de una desventaja: la de la utilización de la categoría como una bolsa sin fondo donde introducir todas aquellas manifestaciones que no eran pintura, ni escultura, ni teatro...

Desde la propia práctica artística, y desde la experiencia docente en la Cátedra de Escenografía de la FBA, se fue delineando la necesidad de indagar en las proximidades y cruces entre el lenguaje de la instalación y el de la gestación del espacio escénico, en el que los alumnos son formados desde que eligen la especialidad, a efectos de consolidar la apertura que se había ido gestando en el campo de la producción. 
Pronto pudo advertirse una cuestión que ofreció particular interés: toda vez que un texto (analítico, crítico, académico, de difusión) debía dar cuenta de las características de una instalación determinada, recurría insistentemente a términos vinculados con la práctica teatral: así encontramos en la prensa que "La obra de Boltanski es cada vez más teatral y escenográfica. Sus instalaciones son puestas en escena y así sucede con Migrantes" (Lebenglik, 2012). Y que lo que aparece en la muestra reciente de Julio Le Parc en el Malba "... es el encanto del teatro, de la puesta en escena, de la luz facetada, ondulada, fragmentada, que rebota en el cuerpo de los otros y en los ojos propios como un destello". (Viña, 2014)

El parentesco de hecho que parece emerger de estas asociaciones libres contribuyó a perfilar los alcances de este trabajo: intuiciones que vinculaban los espacios del teatro y la instalación, paralelismos en torno al tiempo de configuración de un suceso o acontecimiento de características singulares, y la consiguiente pregunta por el rol del espectador.

De esta manera fue perfilándose la hipótesis de que las instalaciones en las que el espectador se adentra físicamente para vivenciar la obra pueden ser concebidas como dispositivos escénicos que sientan las bases para la configuración de una nueva tipología: la de un espectador-actor.

A través de esta investigación, se intentará hacer un aporte a la definición de la instalación como concepto que, a juzgar por la fragmentación y parcialidades observadas, parece estar aún en etapa de construcción, pese a lo difundido de su uso. Se pretende - asimismo - contribuir a la formación artística interdisciplinaria, a través del directo impacto del tema en las Asignaturas Fundamentos Estéticos/Estética y Taller Básico de Escenografía e, indirectamente, en todas las asignaturas teóricas y prácticas del sistema universitario vinculadas al arte contemporáneo.

Se aspira, finalmente, a sentar las bases de una posible transferencia al campo de la educación artística. 


\subsection{Aspectos metodológicos:}

Desde sus orígenes en los años 60, la instalación trató de romper radicalmente con el paradigma del objeto autónomo, trabajando en la construcción de propuestas en las que el espacio en su conjunto se trata como una situación única. En ellas el espectador entra y completa la obra, produciendo una interacción que sucede en un tiempo circunscripto, que se resignifica en el acontecer aquí y ahora.

La forma en que la instalación se relaciona con el espectador ha impactado en el proceso de investigación y escritura de este trabajo. En este sentido, la Filosofía del Teatro, desarrollada por Jorge Dubatti, proporciona un punto de vista esencial para el complejo abordaje metodológico que entraña el acontecimiento como objeto de estudio. La instalación, así como el teatro, no puede analizarse sino como acontecimiento de experiencia estética convivial, ya que lo efímero de esa dimensión hace que se consuma en el mismo momento de su producción. Para Dubatti (2012), la investigación teatral implica un ejercicio permanente de la asunción de esa pérdida, en tanto se vive el teatro como presente pero se lo piensa como pasado, como acontecimiento irrecuperable. La imposibilidad de la captura de esa complejidad desde el presente nos obliga a una aproximación desde el rescate de fragmentos e hipótesis, necesariamente parciales y siempre susceptibles de revisión.

La Filosofía del Teatro privilegia la consigna "del ser" (del acontecimiento teatral en su praxis) al "poder ser" (de la teoría teatral), por lo que postula un modelo de investigador participativo, que interviene en la zona de experiencia del acontecimiento, ya sea como artista, espectador o técnico. Y así obtiene materiales a través de su propia vivencia autoanalizada, o bien a través del rescate de metatextos que den cuenta de las experiencias de otros espectadores, técnicos y artistas asistentes al convivio. (Dubatti, 2012: 30-31).

A tales efectos, se abordará en este trabajo el análisis de un corpus de seis instalaciones inmersivas:

- Obliteration room / La habitación del borramiento (2013) de Yayoi Kusama.

- Edificio (2012), de Leandro Erlich. 
- Red rooms-Parents / La habitación del padre (1994), de Louise Bourgeois.

- Marulho (el Murmullo del mar) (1991-1997), de Cildo Meireles.

- Desvio ao vermelho/Desvío al rojo (1967-1984), de Cildo Meireles.

- Migrantes (2012), de Christian Boltanski.

Los casos considerados corresponden, en forma prioritaria, a una selección de aquellos que se han experimentado de primera mano, junto con obras que se han convertido en el foco de observaciones particularmente interesantes de otros actores del panorama artístico (artistas, críticos, curadores), que han registrado en primera persona su propia experiencia en ellas. De esta manera, se intentará dar cuenta de una dimensión vivencial y sensorial capaz de enriquecer la reflexión teórica y el pensamiento crítico.

El acercamiento a dichas impresiones pudo llevarse a cabo a través de un amplio relevamiento de catálogos de exposiciones, artículos críticos y de difusión aparecidos en suplementos culturales. Fueron también de utilidad los registros fotográficos, la consulta de entrevistas realizadas a artistas, críticos y público, y la visualización de registros audiovisuales amateurs, que los usuarios comparten en la web.

Se considerarán tres dimensiones de análisis en torno al rol del espectador en cruce con la construcción espacio temporal de la obra:

1. Una dimensión lúdico-participativa, en la que espacio y objetos se presentan expuestos a la manipulación, por lo que el desarrollo corporal del espectador tiene incidencia material - permanente o provisoria - sobre la obra.

2. Una dimensión de ocupación performativa, en la que el espacio de la obra aloja la corporeidad y el tránsito de un espectador que deviene habitante y organizador del espacio, en tanto se configura como referente y punto de vista dinámico.

3. Una dimensión de circulación significante, en la que el cuerpo que transita se ofrece - espontáneamente- a la mirada del otro, que reconstruye el conjunto como escena. 


\subsection{Mapa del documento:}

En los apartados anteriores - y de acuerdo a los criterios propuestos por la Maestría en Estética y Teoría de las Artes de la UNLP para la formulación de trabajos de tesis - se ha dado cuenta brevemente de los planteos relativos a las motivaciones de la elección del tema, aspectos metodológicos, objetivos, hipótesis y propósitos de esta investigación.

El capítulo 1, (in) Definiciones, se plantea en primer término la dificultad de acotar la naturaleza compleja de la instalación en una definición taxativa. Para ello rastrea en los posicionamientos teóricos más relevantes surgidos desde la apropiación del vocablo por el campo del arte, a efectos de delimitar un recorte necesario que permita deslindar las particularidades de una práctica caracterizada por la falta de especificidad, la pluralidad y la apelación a comportamientos intrínsecamente híbridos.

En el apartado siguiente se dirimen algunos debates en torno a los cruces y coincidencias entre la instalación como práctica artística y la instalación de arte, en tanto dispositivo de exhibición y montaje.

En La obra y el lugar: una relación recíproca, se problematizan las relaciones de la obra y el sitio de emplazamiento, dando origen a una primera delimitación: obras de sitio específico y de sitio orientado. Los dos puntos finales del capítulo se organizan en torno a la propuesta de algunos abordajes posibles: La instalación como dispositivo y Apuntes para una definición descentrada, que circunscriben el enfoque que se adoptará en el proyecto.

El Capítulo 2 aborda una lectura minuciosa del arte minimalista de los 60, en tanto antecedente directo de la incorporación del espacio circundante en la experiencia estética del espectador, y por lo tanto, central para entender tanto la relación espectador - obra como obra - entorno. Se desanda el abordaje del texto crítico de Michael Fried, "Arte y Objetualidad", insoslayable como marco teórico, en que aparece, por primera vez la adjetivación de teatral aplicada al arte contemporáneo, en este caso como expresión de marcada calificación despectiva. A continuación se lo contrasta con las ulteriores perspectivas de Hal Foster y Georges Didi-Huberman, que han revisado a conciencia el trabajo de Fried y 
aportado análisis igualmente significativos en torno al minimalismo. Los tres autores, en conjunto, proporcionan líneas de análisis de sumo interés para la construcción de categorías conceptuales (tales como las de teatral, presencia, sujeto/objeto - entre otras) centrales para la comprensión y análisis de las instalaciones.

El Capítulo 3 se introduce en el devenir de la noción de lo teatral en el S XX, como categoría que trasciende los límites de lo escénico y salta a otros campos, especialmente el de las artes visuales, construyendo territorios liminales 0 umbrales de frontera entre las disciplinas.

Se aborda un acercamiento a la etimología de la palabra teatro, y se advierten los puntos de contacto que establece con la doble perspectiva que implica no sólo el mirar sino el ser mirado, centrales para la comprensión de la articulación entre las artes visuales y las artes performativas.

Se indaga más tarde en la perspectiva de Jorge Dubatti en relación a la concepción del teatro como acontecimiento, y su condición deudora del acontecimiento convivial como institución ancestral y práctica de socialización; y el escalonamiento múltiple que organiza la espacialidad teatral, aspectos que se contrastan más tarde con la práctica de la instalación, a efectos de proponer algunos criterios posibles respecto de la dimensión teatral de las instalaciones.

El Capítulo 4 profundiza en las particularidades de la recepción en las obras inmersivas: el espectador no se encuentra ya frente a un objeto único y materializado sino incluido en un ensamble de relaciones, que dan origen a un lugar para la experimentación espacial. De allí que la experiencia perceptiva sea, en sí misma, un problema determinante de la obra, y de esta investigación.

Por eso en apartados sucesivos se indaga en torno a las categorías de presencia, uso, experiencia y tránsito como dimensiones que se conjugan para proponer un nuevo modelo de espectador: un espectador-actor. Estas categorías se aplican al análisis de seis casos que permiten dar cuenta de diferentes modos de producción y de recepción en la práctica que nos ocupa y posibilitan individualizar algunas posibles tipologías de espectador. 
La instalación es analizada como acontecimiento, inscripta en unas coordenadas espacio-temporales particulares y efímeras que construyen una situación única que el espectador completa con su experiencia, perspectiva que da lugar a repensar, a continuación, la posible naturaleza aurática de la práctica y sus permanentes tensiones entre las condiciones de unicidad y reproductibilidad, en tanto emergente de una experiencia estética que atraviesa la frontera entre el espacio de la vida cotidiana y el espacio simbólico del arte.

Por último se presentan las Conclusiones, que no pretenden erigirse en posiciones cerradas y excluyentes, sino que se proyectan como la apertura de un camino de estudio fundado en estas prácticas artísticas consideradas relevantes tanto en la dinámica del arte contemporáneo como en el ámbito de la educación artística.

Estos aspectos tienen continuidad en un nuevo proyecto - actualmente en desarrollo-, enmarcado en el Doctorado en Artes de la FBA, que focaliza en la dimensión política de las instalaciones en el arte contemporáneo latinoamericano. 


\section{CAPÍTULO 1: (in) Definiciones}




\subsection{El problema de la denominación.}

(...) hay varias respuestas a la pregunta [qué es la instalación], pero ninguna tan directa como aquella que informa que la pintura tiene que ver con la aplicación de pigmentos pictóricos, la escultura con la idea de los objetos tridimensionales, el grabado con las técnicas de transferencia y la fotografía con el uso de película y papel sensible a la luz. (A. Geczy - B. Genocchio - What is installation? 2001)

En una etapa temprana de este proyecto, se advirtió lo que se dio en llamar el problema de la denominación, es decir, la compleja tarea de intentar definir los alcances del concepto instalación. Un rápido vistazo por museos, galerías y publicaciones de arte contemporáneo permitió observar que el término se aplica a un repertorio complejo de producciones, difícilmente equiparables en sus aspectos formales y matéricos. De esta manera, una definición rigurosa sería incapaz de incluir una buena parte de ellas. Consideremos algunos ejemplos:

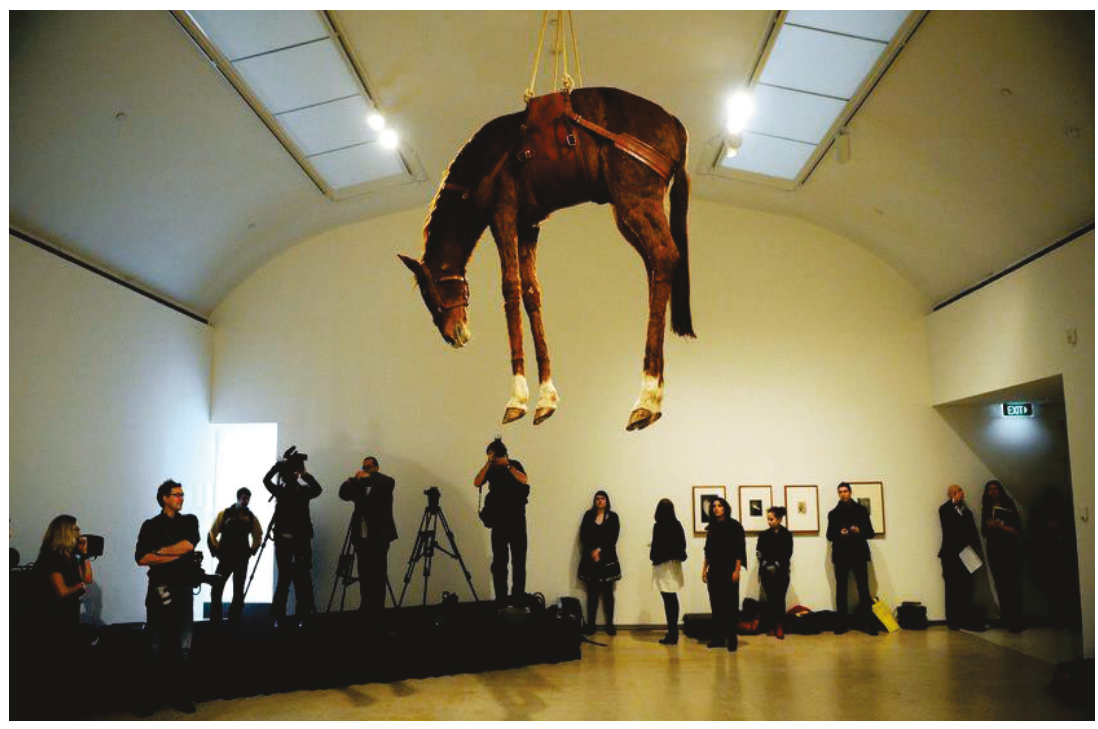

Figura 2: Vista de la instalación Novecento (1997), de Mauricio Cattelan en Museo de Arte Contemporáneo de Sydney. 2000. 


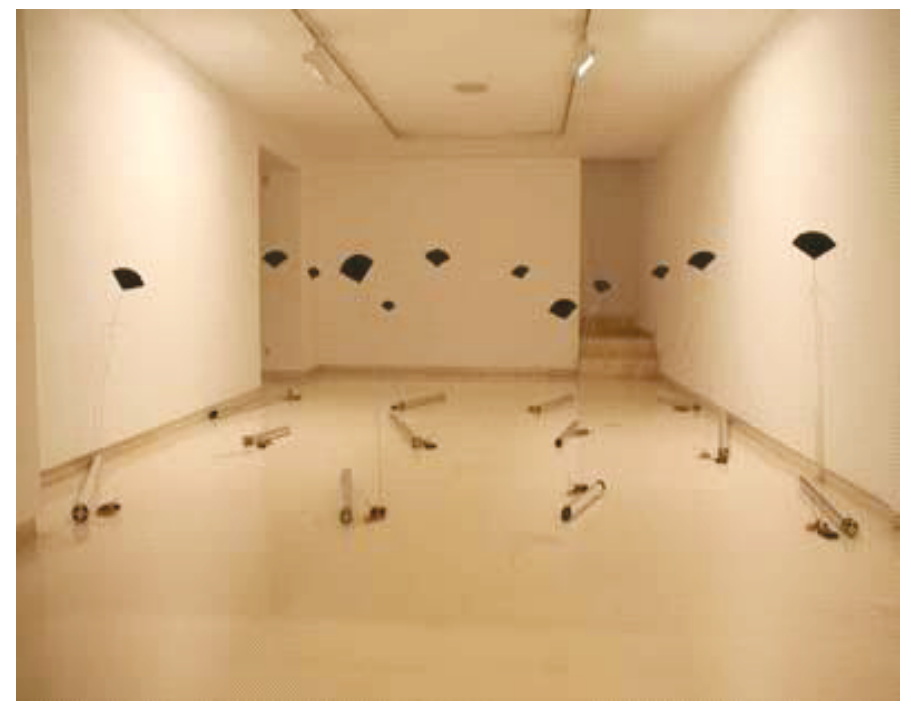

Figura 3: Vista de la instalación Para Eolo, de José Antonio Orts en Sala Pelaires. Palma de Mallorca. 2008.
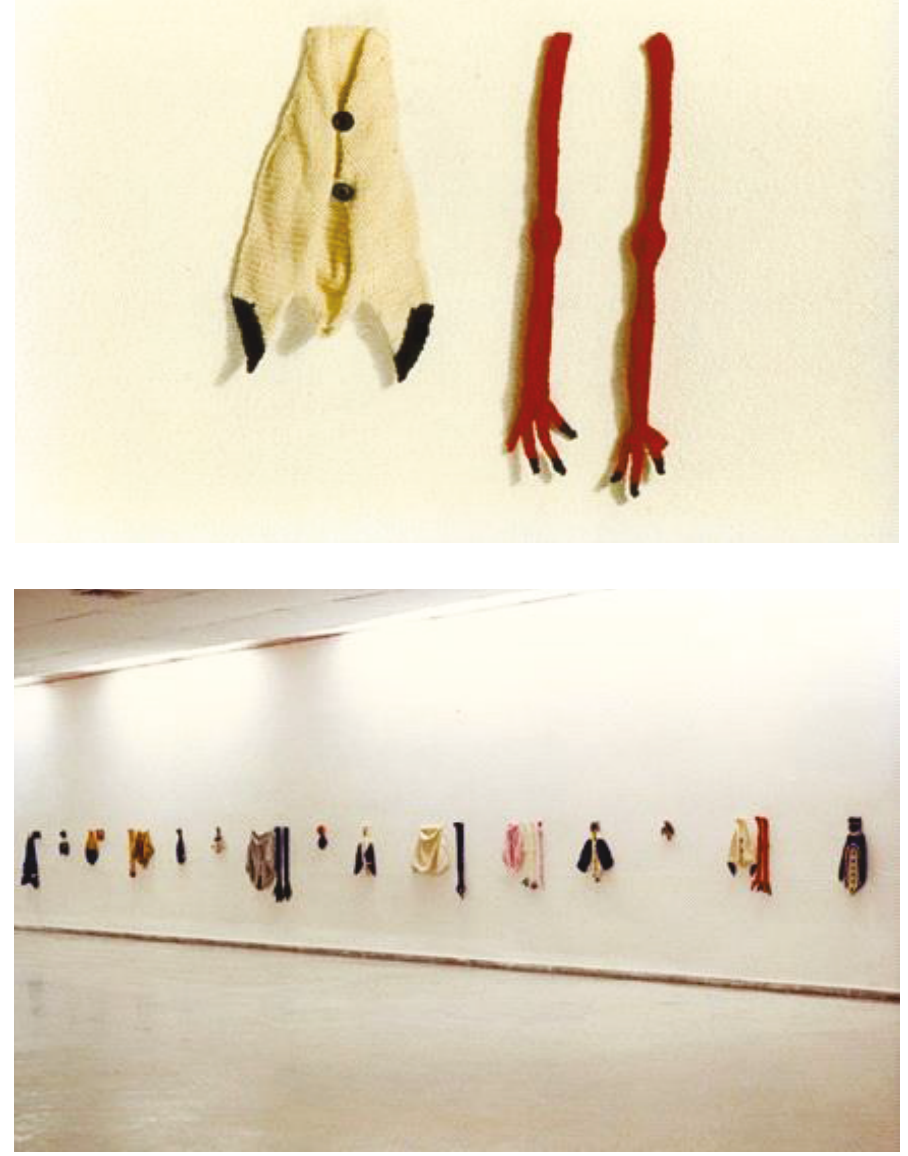

Figuras 4 y 5: Ajuar para un conquistador (1993), de Mónica Girón. Instalación de pared de medidas variables 


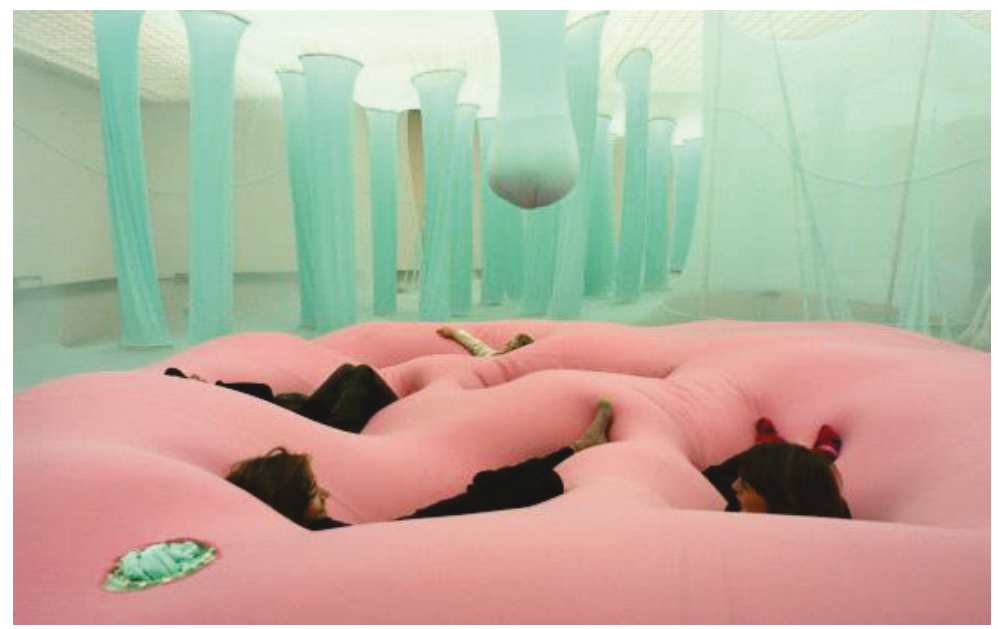

Figura 6: Vista de la instalación Célula Nave, de Ernesto Neto en Museo Boijmans Van Beuningen. Rotterdam (2004)

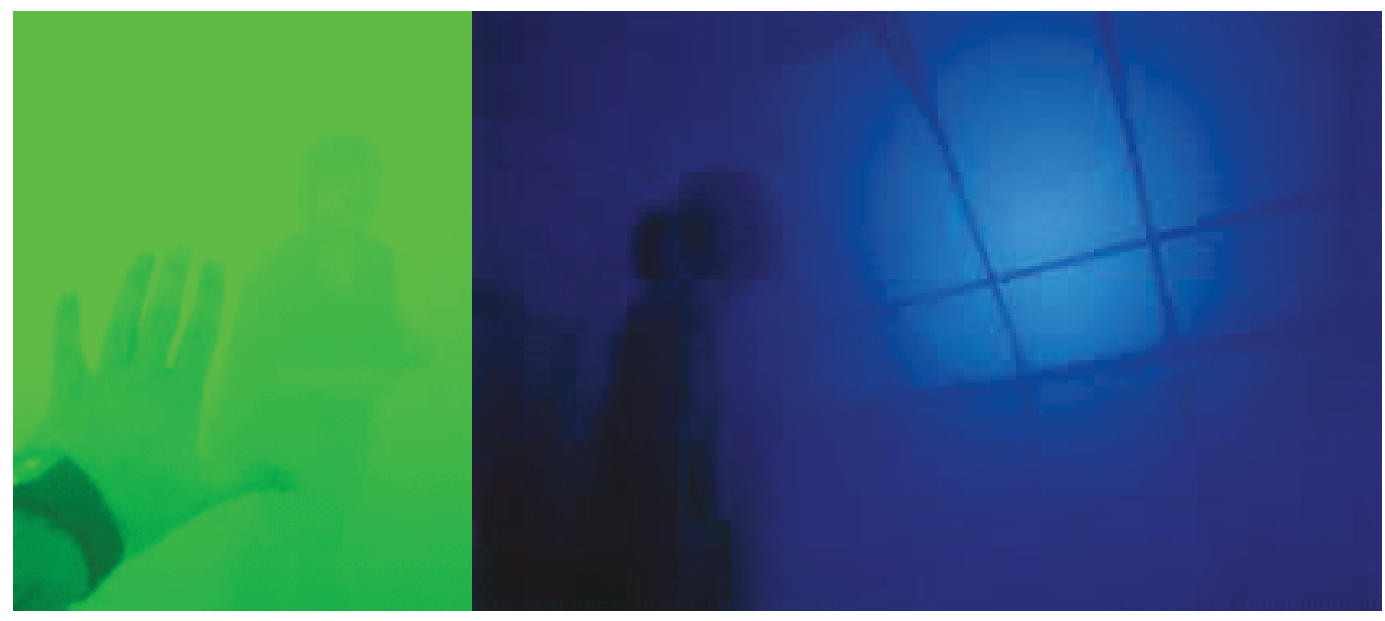

Figura 7: Instalaciones de niebla - Anne Veronica Janssens

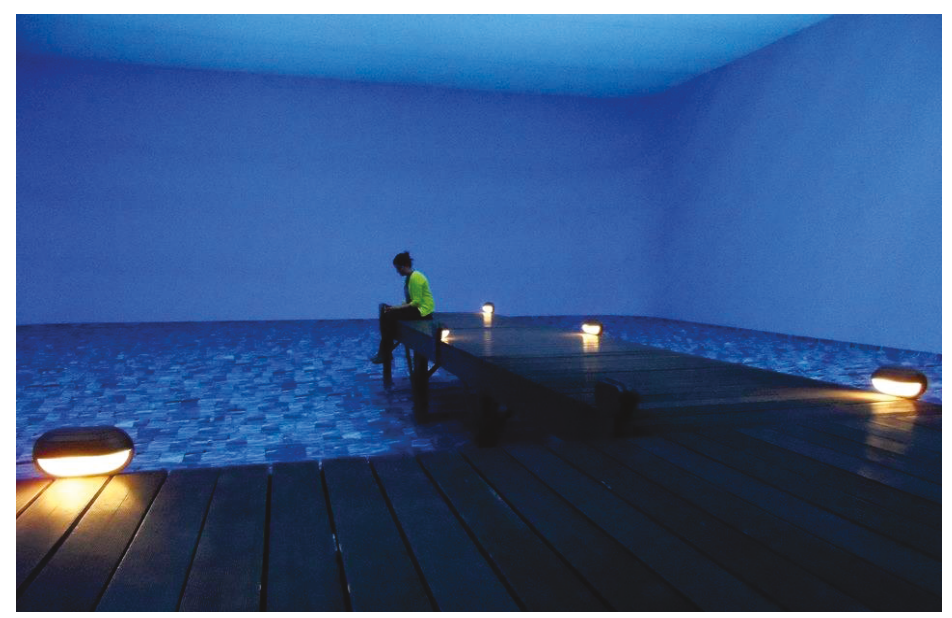

Figura 8: Marhullo (el murmullo del mar) de Cildo Meireles, en Hangar Bicocca, Milán (2014) 


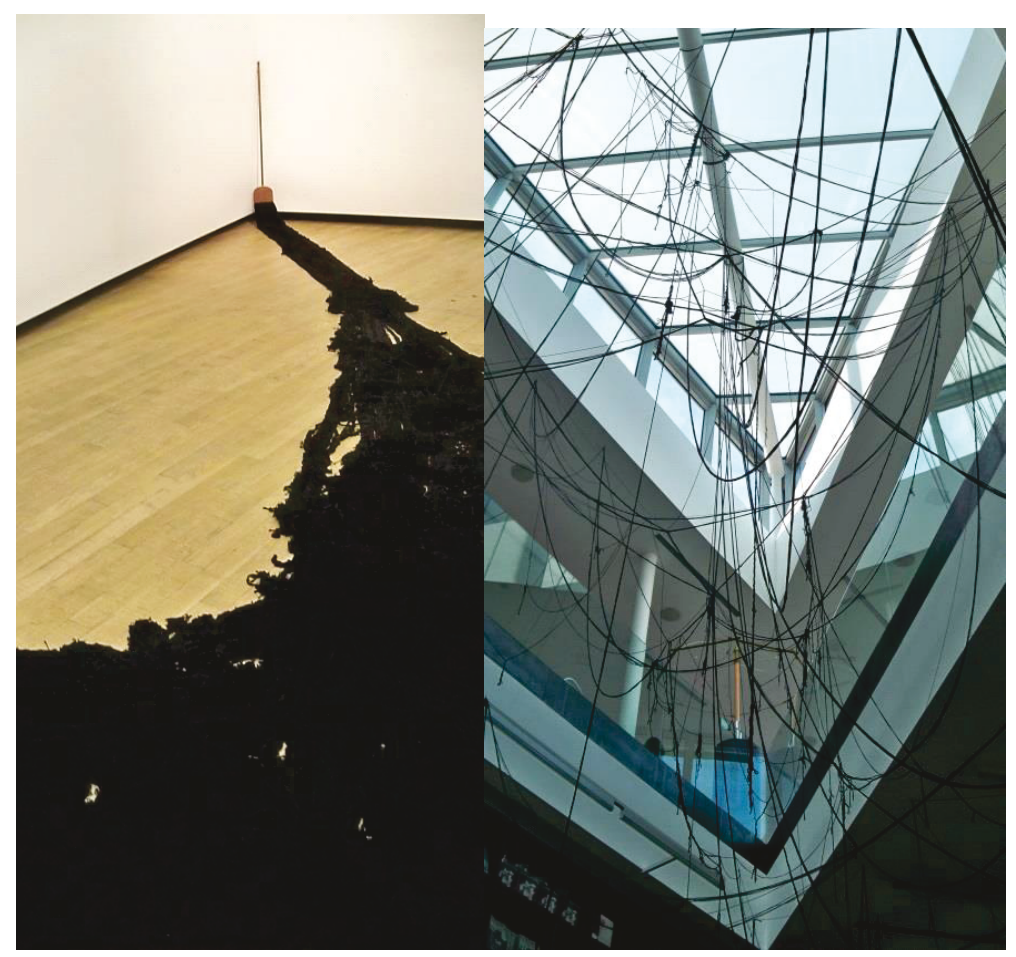

Figuras 9 y 10: Vistas de la instalación La Bruja, de Cildo Meireles en PROA. CABA (2012)

Como esta breve selección de imágenes permite observar, el de instalación se revela como un concepto inestable, que ha logrado encauzar a un grupo heterogéneo de prácticas artísticas difíciles de catalogar, que no encuentran clasificación posible en el orden de las categorías artísticas tradicionales. No es posible afirmar que respondan a cuestiones morfológicas concretas, ni que sea la técnica la que las dote de singularidad, sino que se relacionan más bien con una determinada manera de proponer arte. Así, bajo una misma denominación conviven producciones tan diversas como el paisaje tridimensional y transitable de Marulho de Meireles (Figura 8), y Ajuar para un conquistador, de Mónica Girón (Figuras 4 y 5). La primera, con su inmenso mar (producto de una metáfora tanto visual como sonora) de ondulantes hojas de papel azul que ocupa la totalidad del espacio exhibitivo; la segunda desplegada como un sutil conjunto de pequeñas prendas tejidas para los pájaros patagónicos: las piezas - un diminuto pullover con capucha y alitas, un par de medias larguísimas que rematan en unas patas 
de cuatro dedos - refieren a una labor íntima y cotidiana, propia del espacio privado, y se presentan sencillamente colgadas de la pared.

Bajo la misma denominación quedan comprendidas también las inmateriales nieblas artificiales de Anne Verónica Janssens (Figura 7), en una puesta que se dispone a alterar la densidad de los espacios en que se inscribe. Las sensaciones visuales y auditivas son modeladas y atenuadas para configurar un espacio onírico, un lugar donde las aristas constructivas de la sala apenas pueden adivinarse $y$ en el cual los transeúntes ocasionales emergen como figuras espectrales.

Con ellas, los caballos taxidérmicos del provocador Maurizio Cattelan (Figura 2), los dispositivos electrónicos interactivos de Orts (Figura 3) y la infinita madeja de hilo negro de una obra paradigmática como La Bruja (Figuras 9 y 10) - que poniendo en cuestión toda proporción lógica escapa de una pequeña escoba alojada en un rincón para apropiarse del espacio museístico en su totalidad -, nos permiten intuir que en el arte contemporáneo casi todo se ha convertido en instalación.

Por eso es que, como práctica intrínsecamente híbrida, que promueve la articulación de diferentes formas y dispositivos artísticos, intentar definirla nos introduce en un territorio escurridizo y abierto a un sinnúmero de interpretaciones.

Las inquietudes iniciales tendientes a explicar sus alcances pueden rastrearse más en el campo de la producción artística, su recepción y su crítica, que en el ámbito académico reflexivo. La introducción del término en el terreno de la creación artística se remite al contexto del arte minimalista, en los años 60. En esta década, el arte inauguraría una profunda transformación que perseguía la intensificación de la experiencia del espectador, a través de diversas estrategias que lo apartaban del cómodo papel de voyeur para transformarlo en parte constitutiva de la obra. De este modo, se procuraba la fusión de las esferas del arte y de la vida, construyendo tiempos y espacios artísticos experimentables y concretos - estrategia ciertamente opositora a los criterios postulados por la modernidad -, a través de cruces e hibridaciones que imposibilitaron todo tipo de categorizaciones certeras. Donald Judd, por ejemplo, publica en 1965 en la 
revista Art Yearbook un artículo titulado "Specific objects" en el que manifiesta que:

... más de la mitad de las nuevas, las mejores obras de los últimos años, no son pintura ni escultura. Por lo general, tienen un vínculo, cercano o lejano, con una u otra. Las obras son diferentes, y mucho de su contenido, que no es pintura ni escultura, es asimismo diferente... Las nuevas obras en tres dimensiones no forman un movimiento, una escuela o un estilo (Judd, 1965: 8)

Similar desconcierto alcanzaba, incluso a los teóricos más experimentados del momento. Douglas Crimp describe la impresión que le causó una muestra individual de Morris, que tuvo lugar en un depósito de muebles, en 1968, señalando que había "objetos que desafiaban todas nuestras expectativas respecto a la forma que debía tener una obra de arte y el modo en que debía ser expuesta". (Tejeda, 2006: 18)

A principios de los sesenta los términos utilizados para designar a estas obras logradas mediante la colocación de materiales en un espacio dado eran los de "ensamblaje" y environment, en tanto que el vocablo instalación aludía sólo al modo en que una exposición había sido planteada. Diez años más tarde tampoco existiría consenso a la hora de nominar estos nuevos comportamientos artísticos: si bien Dan Flavin ya había utilizado en 1968 el término instalación para sus obras con tubos fluorescentes ${ }^{1}$, hasta los años ochenta convivirían aun denominaciones diversas tales como ambientes, lugares, objetos específicos y esculturas. Hacia fines de los setenta Rosalind Krauss observa la tendencia de la última década de reclamar para todo tipo de experiencia artística algún tipo de categoría escultórica, señalando el abuso que se hacía del término. Por eso inaugura el concepto de campo expandido para problematizar todas aquellas prácticas suspendidas entre las ideas de no paisaje y no arquitectura. ${ }^{2}$

\footnotetext{
${ }^{1}$ Lesley Johnstone señala que el uso del término por parte de Flavin para designar sus obras con tubos de neón de diversos tamaños y colores supuso un problema de clasificación dentro de las artes plásticas tradicionales: podían ser esculturas, objetos de luz, ambientes... o se podía utilizar un término más apropiado para los gremios de electricidad, fontanería o carpintería: instalaciones (citado por Bonet, en Gianetti, 1995: 25)

2 El punto central del análisis de Krauss del campo de la forma escultórica lo constituía su caracterización de ésta en un orden de doble negatividad. De esta forma, Escultura se definía como aquello que «estando en la arquitectura no era arquitectura» y/o aquello que «estando en el paisaje no era paisaje». Esta distinción permitía considerar dos modalidades: por un lado, la escultura al aire libre, y por otro la escultura arquitectónica, de interior o exterior. Ornamento para jardines o decoración para arquitecturas burguesas, la tensión de la escultura hacia estos dos límites encontrará su punto intermedio en la plaza pública, en el contexto urbano: en ese lugar que, por
} 
Sólo en momentos posteriores se fueron sumando construcciones teóricas más elaboradas, en tanto el tema fue tomado como objeto de estudios más sistematizados. No obstante, la noción de "instalaciones" que se fue perfilando, continuó habilitando perspectivas múltiples, parciales y complejas, de las que pretende dar cuenta esta breve selección:

- [...] un despliegue de diversos elementos en el espacio tridimensional y en las coordenadas del tiempo, una articulación idiosincrática de [...] elementos en un conjunto unitario, un concepto no canónico antes que un formato, una técnica, un estilo, una tendencia (Bonet, 1995).

- (...) borra las líneas de separación de las diferentes formas de hacer arte, entre pintura, escultura, arquitectura, fotografía, cine y vídeo, readymades, teatro y arte vivo, música, etc. (...) confunde el rol del artista con el del espectador. Funde arte y vida (...) No es sólo otra forma de hacer arte. Instalación es en lo que se ha convertido todo el arte (...) por lo tanto "instalación" es una tautología (Watkins, 1997: 26)

- El arte de la instalación (...) puede ser abstracto o pictórico, espontáneo o controlado. Siempre hay relaciones recíprocas de diferentes tipos entre el espectador y la obra, la obra y el espacio, y el espacio y el espectador (...) (Reiss, 1999:13)

- Como una especie de collage expandido (entre el media sculpture, el assemblage y el environment) la instalación construye una escenografía, un decorado, una arquitectura que quiere ser habitada y experimentada por el espectador (Suderburg, 2000: 36)

- (...) un tipo de manifestación artística tridimensional, interesada principalmente en la manipulación y activación del espacio en el proceso de relacionar elementos, tradicionalmente separados, en un todo articulado, $y$ concentrado en la idea de interacción entre obra y experiencia física, subjetiva y temporal del espectador" (Sánchez Argilés, 2009: 19).

ser «urbanismo», tierra y artificio, es a la vez paisaje y arquitectura -y que, justamente entonces, no es del todo ni una ni otra.

La aplicación en este esquema, fundado en el carácter mutuamente contrario de arquitectura y paisaje, le permitió a Rosalind Krauss diseñar su famoso «campo expandido» en el que lograría, dar cabida a los territorios más característicos de desarrollo de la práctica escultórica de los años 6070.

$\mathrm{Si}$, según su tesis, el encuentro doblemente negativo de arquitectura y paisaje daba lugar al tradicional dominio escultórico, la pregunta fundamental entonces era qué ocurriría con los posibles otros tres lugares de encuentro que se perfilaban en ese campo ampliado (en las que tendríamos sucesivamente no paisaje, paisaje, arquitectura y no arquitectura). La tesis de Krauss era que ese campo expandido era precisamente el territorio que la escultura de los años sesenta y setenta llegó a ocupar. 
Estas perspectivas - entre otras - permiten avizorar en la instalación una cierta tendencia a lo complejo, sustentada en sus apetencias interdisciplinares y su apariencia variable en el espacio y el tiempo. Todas ellas destacan la imposibilidad de arribar a definiciones unívocas, pero dan cuenta de cierto consenso en el manejo de los términos, y señalan algunas características recurrentes, tales como la tendencia a la disolución de los límites, el desbordamiento disciplinar y la confusión de roles, así como una cierta ambición totalizadora del espacio.

En este sentido, pueden extraerse de su análisis algunas ideas principales:

- El marcado carácter ecléctico, la falta de pretensión de pureza o especificidad formal; la carencia de condiciones precisas que hagan que una instalación sea experimentada como tal (Sánchez Argilés, 2009: 24)

- La importancia de la inscripción topológica de los objetos que la conforman dentro de unas coordenadas espaciales y temporales específicas, contextualización que logra extraerlos del espacio anónimo de la vida cotidiana y llevarlos a adoptar un trato tal que les otorgue estatuto de obra. De este modo, la instalación proporciona a los distintos soportes, medios y géneros artísticos tradicionales la posibilidad de acceder a unas condiciones de exhibición que los activa, configurándose como un lugar en el espacio, y otorgándoles la posibilidad de asumir un recorrido visual y experiencial que permite que un conjunto de gestos, ideas y materiales conformen un conjunto singular. En estos términos la puesta en escena devuelve a la obra su condición de "original" en el mundo del arte. (Larrañaga, 2008: 128-129).

- La presencia de un observador que se adentra físicamente en la obra para experimentarla, y cuya presencia deviene en parte constitutiva e inseparable de la obra misma. Dado que la instalación no se circunscribe al conjunto de elementos materiales que la conforman sino que comprende las relaciones espaciales que se establecen entre ellos, la interacción con el cuerpo del espectador resulta esencial en el proceso creativo y perceptivo. 
Las reflexiones en torno al cruce de estos dos últimos aspectos establecen el punto de partida de esta tesis. En ella nos proponemos indagar en la posible cualidad escénica de la instalación, a partir del supuesto de que esta se construye en torno a la presencia de un espectador inmerso que, al habitarla, la completa y dota de sentido, a partir de la vivencia que experimenta en el interior de la obra.

\subsection{Espacio expositivo, arte, escultura o qué?}

Adam Geczy y Benjamin Genocchio (2001) señalan que "/o que uno ve en una instalación artística es el contexto en que el arte está teniendo lugar", perspectiva que remite a una forma particular de exponer, y a la capacidad de estas obras de interpelar a un espacio artístico al que toman como objeto de su reflexión. Así, las relaciones entre los objetos, más que los objeto en sí mismos constituyen la especificidad principal del arte de la instalación. De allí que se la suela considerar como la forma arquetípica del arte contemporáneo, dado que como éste, opera insistentemente en el nivel del contexto. ${ }^{3}$

Resulta oportuno recordar que antes de que se consolidara en los años ochenta para definir un nuevo tipo de práctica artística, el término instalación era utilizado en el campo del arte para dar cuenta del proceso de colocación de obras para su exhibición, en un conjunto coherente, actividad próxima a la que realizan en la actualidad los curadores ${ }^{4}$. Es por eso que el uso de la palabra inglesa installation como sinónimo de montaje expositivo ha complicado a menudo el campo semántico de estas producciones. Claro está que un montaje de exposición coincide, en parte, con nuestro objeto de estudio, sobre todo por el interés en la distribución de objetos en un espacio y su relación con la interacción que se

\footnotetext{
${ }^{3}$ En "Topología del Arte Contemporáneo" Boris Groys sostiene que si el arte Moderno trabajó en el nivel de las formas individuales, el contemporáneo está trabajando en el nivel del contexto, de la construcción del marco que ofrece a la obra la posibilidad de una nueva interpretación teórica. Por eso lo considera - antes que un generador de obras individuales -, una manifestación de una decisión: la de reconocer una determinada imagen como original o como copia de acuerdo al contexto, al escenario donde esa decisión se toma. (Groys, 2008: 4)

${ }^{4}$ Esta ambigüedad está presente desde los primeros usos del término en la década de 1960. Por entonces la palabra instalación fue empleada por las revistas de arte para describir la forma en que se organizaba una exposición. El registro fotográfico de las modificaciones que se realizaban en estos casos, dio lugar al uso conjunto del espacio como "arte de la instalación". Desde entonces, esta distinción entre instalación de obras e instalaciones de arte se hizo cada vez más borrosa.
} 
establecerá entre el sujeto-espectador y la obra. Lo que ambos términos tienen en común es el deseo de aumentar la conciencia del espectador respecto de los objetos instalados en un espacio, y de su respuesta corporal frente a ellos. Sin embargo hay una diferencia sustancial entre ambas prácticas, señalada por Claire Bishop (2001): Un montaje de arte es subsidiario de los trabajos individuales que presenta, mientras que en una instalación, el espacio, y el conjunto de los elementos que la componen, se consideran en su conjunto como una entidad singular, que crea una situación en la que el espectador entra físicamente. En ella se establecen tensiones entre las partes que inciden en la lectura e interpretación de la obra, en tanto que el montaje trabaja a partir de obras cuya autonomía deberá asegurar, aunque puedan vincularse para construir una entidad mayor: la de la muestra en su conjunto.

No obstante y por lo expuesto anteriormente, resulta posible rastrear en la historia de las prácticas expositivas de vanguardia - tales como las dadaístas, constructivistas y surrealistas, entre otras - múltiples antecedentes para la comprensión y desarrollo del arte de la instalación. Por eso Marti Perán sostiene que la evolución de la escultura minimalista permite observar que, al coincidir la escultura con la modulación del espacio donde esta se produce, este espacio resultante - el espacio obrado - es siempre el espacio del arte, "... y no tanto desde una perspectiva ontológica (el espacio donde el arte aparece) sino desde una perspectiva institucional (el espacio - museo o galería - donde se da por supuesto que lo que ahí se ofrece está sancionado como arte)" (Perán, 2003: 2). Así, los comienzos de la institucionalización de las instalaciones se fusionan con las estrategias del arte de los sesenta para adueñarse del espacio expositivo, entre las que los espacios alternativos - almacenes, edificios abandonados, etc. fueron considerados especialmente propicios para la creación y exhibición de obras que exploraban la relación entre contexto y contenido.

En este sentido puede decirse que la instalación es heredera del arte minimalista, en cuanto a la atención prestada a ese contexto y al cuerpo del espectador, y del arte conceptual en relación al cuestionamiento de la noción de arte a través de su relación con lo real. 
Pese a ubicarse claramente en un campo interartístico, y por su origen en el ámbito de las prácticas minimalistas, es fácil comprender que se haya tendido a considerarla simplemente como una ampliación de la escultura. Pero esta consideración referirá, sin duda, al estallido de dicho concepto, que llevó a Rosalind Krauss a proponer la categoría de campo expandido. Retomándola, Javier Maderuelo señala que el desbordamiento que se produce, por efecto de la descentralización de la obra escultórica, constituye el paso más decisivo para que la escultura se apodere del espacio que se encuentra a su alrededor y lo incorpore a la propia obra. De este modo, el espacio «no ocupado» por la escultura cobra tanta significación como el espacio ocupado, convirtiéndose así, conjuntamente, todo el espacio en escultura. El autor explica que:

[...] las obras no pretenden atraer la atención del espectador sobre su fisicidad, sino que carentes de centro, pretenden establecer relaciones con el espacio en el que se encuentran instaladas (Maderuelo, 1990).

En líneas generales, la selección de objetos y su presentación dentro de determinadas coordenadas espacio-temporales parecen configurar las únicas características esenciales de la instalación. A propósito de esto, Boris Groys sostiene que su origen radica en un proceso de selección (con su lógica propia de inclusiones y exclusiones) que es revelador de la materialidad de la cultura en que vivimos, "porque instala todo aquello que nuestra civilización simplemente hace circular" (Groys, 2008: 6). Así, los objetos e imágenes del propio contexto son relocalizados y puestos en juego para producir sentido; pero no para reproducir una relación ya existente sino para articular un nuevo discurso, subjetivo e individual. El artista ruso Ilya Kabakov - considerado uno de los padres de la instalación - destaca que todos los elementos allí presentes son conocidos, pero que la resultante no es la suma de ellos, sino una entidad completamente nueva:

(la instalación) está a la merced absoluta del espectador que puede acercarse y comprobar, por sí mismo, que esto no es más que un balde. (...) Este es un arte anti-ilusionista. $Y$, sin embargo, Algo es creado por estos baldes, estos palos $y$ todos estos objetos completamente reales" (Kabakov \& Groys, 1990: 4).

Groys afirma que los objetos que conforman una instalación tienen destinos separados, es decir, que no constituyen una unidad indisoluble, lo que les habilita 
una posible existencia independiente por fuera de ese marco y los vuelve reemplazables. De allí que podamos afirmar que el estatuto de obra se plantea en relación al espacio de la instalación entendido como confluencia y totalidad, como relación y construcción, y no sólo como la suma de elementos aislados. Al tomar al propio espacio como materia - y dado que el espacio representa la condición más general del mundo material y perceptible - la instalación tiende a absorber los signos identitarios de las otras disciplinas, a las que ofrece un lugar en su espacio. De allí que suela afirmarse que incluye o contiene a todas las demás formas de arte, a la manera de una práctica de exhibición.

Pero etimológicamente, instalar supone, además de colocar, investir o conferir dignidad (Larrañaga, 2001: 31). Desde esta perspectiva podemos afirmar que la instalación instituye un espacio significativo, al conferir a las coordenadas de espacio y tiempo que ocupa una dignidad especial, que les otorga jerarquía y estatuto de obra.

\subsection{La obra y el lugar: una relación recíproca.}

El lugar en que acontece un evento, acción u obra de arte siempre ha dotado de un plus de significación al objeto que contiene, modificando el modo en que el espectador lo recibe y lo interpreta. Esto resulta especialmente significativo en la práctica de la instalación, en la que el espacio circundante forma parte de la propia obra: al tratarse de un dispositivo íntimamente ligado a su localización espacial y a la experimentación que ese espacio obrado determina, su adecuación con el sitio en que se implanta reviste la mayor relevancia.

Ilya Kabakob reflexiona sobre la importancia del lugar en relación a las cosas, señalando que:

En occidente, las relaciones entre el objeto y el entorno se basan en la primacía, en el predominio exclusivo del objeto (...) en cambio el lugar (donde éstos se sitúan) ha perdido su significado particular, se ha vuelto inexpresivo... se esfuerza en todo lo posible por no atraer la atención sobre él mismo y por funcionar solamente como lugar de acogida para esos objetos (Kabakov citado en Aninat, 2004: 19) 
En este marco, las instalaciones han podido verse como un medio para volver a relacionar el arte con el lugar, puesto que se detienen habitualmente a reflexionar sobre éste, sobre sus dimensiones y características formales, su historia, sus referencias y demás rasgos identitarios. La arquitectura supone un factor fundamental en esa construcción de identidad, puesto que fija los límites desde los cuales se instala la obra, al definir las limitaciones y posibilidades concretas de emplazamiento.

Al apropiarse del lugar en que se exhibe, la obra toma posesión de él y lo resignifica, delineándolo, no ya como soporte, sino como territorio de relaciones, experiencias y cruces, que esboza un nuevo espacio en un espacio anterior.

Es en este sentido que Josu Larrañaga (2001) sostiene que la obra de arte convierte al sitio en que se aloja en una escena, porque la experiencia de ese espacio en relación con las imágenes y textos propuestos por el artista, constituye la propia obra (Larrañaga, 2001: 55). De esta manera, obra y sitio construyen una relación recíproca, en la que la primera transforma al espacio en escena, y éste - a su vez - proporciona caracteres indisociables que entran a formar parte de la trama poética.

Por eso en el contexto del surgimiento de la instalación, fueron frecuentes los debates en torno a su naturaleza efímera y su vinculación con la desmaterialización de la obra y la crítica institucional; en ese marco se consolidó la idea de que el emplazamiento proporcionaba a la obra gran parte de su contenido, por lo que trasladarla, arrancándola del espacio que le daba origen y sentido (desde un punto de vista físico y /o conceptual), suponía la completa y permanente destrucción de la misma. De allí que el impacto del lugar sobre el valor del arte constituyera un tema central para los artistas de los setenta, y se afianzara la noción de arte de sitio específico. En este sentido, Mónica Sánchez Argilés observa que

La vanguardia [...] demandó la experiencia de una fenomenología experimentada corporalmente y reaccionó contra el sistema del mercado apoyado en la obra autónoma, enfatizó la importancia del "sitio" y la contingencia del contexto en la experiencia estética. El trabajo de "sitio específico", en su temprana formulación, se centró en el establecimiento de una relación inextricable e indivisible entre la obra y el lugar, demandando la presencia física del espectador para el completo entendimiento del arte (Sánchez Argilés, 2009: 27). 
En nuestros días - y aunque continúan produciéndose obras para un emplazamiento particular -, parecen haberse multiplicado las relaciones de significado que una instalación puede presentar con su entorno: Larrañaga, por ejemplo, distingue aquellos casos en los que la instalación ocupa un espacio, de otros en los que actúa directamente sobre él. En el primero, el lugar y la obra propiamente dicha apenas interfieren; en tanto que, en los otros, los límites entre el espacio expositivo y la obra llegan a hacerse difusos. Esto resulta de particular interés cuando se trata de un espacio fuertemente cargado de significaciones, lo que podríamos definir como un espacio connotado. Así, la estructura arquitectónica original, las referencias históricas, las asociaciones culturales y los demás componentes que hacen a la identidad única y propia de un lugar, pueden ser exhaustivamente analizados e integrados para conformar los fundamentos de un proyecto artístico. En esos casos, hablamos aún hoy de obras de sitio específico.

Este es el caso de Migrantes (Figura 11), obra que Cristian Boltanski creó en 2012 como parte del Proyecto Boltanski Buenos Aires, para el Hotel de Inmigrantes, actual sede de algunas dependencias de la Dirección General de Migraciones y del Museo de la Inmigración.

A través de Migrantes, el artista se apropió del espacio a partir del supuesto de que "apropiarse no sólo significa tomar posesión de las condiciones físicas de un lugar sino también asumir su identidad como elemento condicionante de esa apropiación" (Aninat, 2004). Así, la historia, la función original del Hotel, su memoria y sus significados fueron retomados por Boltanski y revisados a la luz de los temas recurrentes en sus obras: la identidad, la memoria, el olvido, la tensión entre la vida y la muerte.

Dado que el trabajo de sitio específico se construye en el intercambio entre la obra y el lugar donde trata de cobrar sentido, en ese mismo intercambio se activa una conciencia particular del espacio y del tiempo, que es lo que define la experiencia de la obra. De allí que promueva tanto la reflexión sobre el espacio contenedor como la problematización de la situación convencional del espectador. 


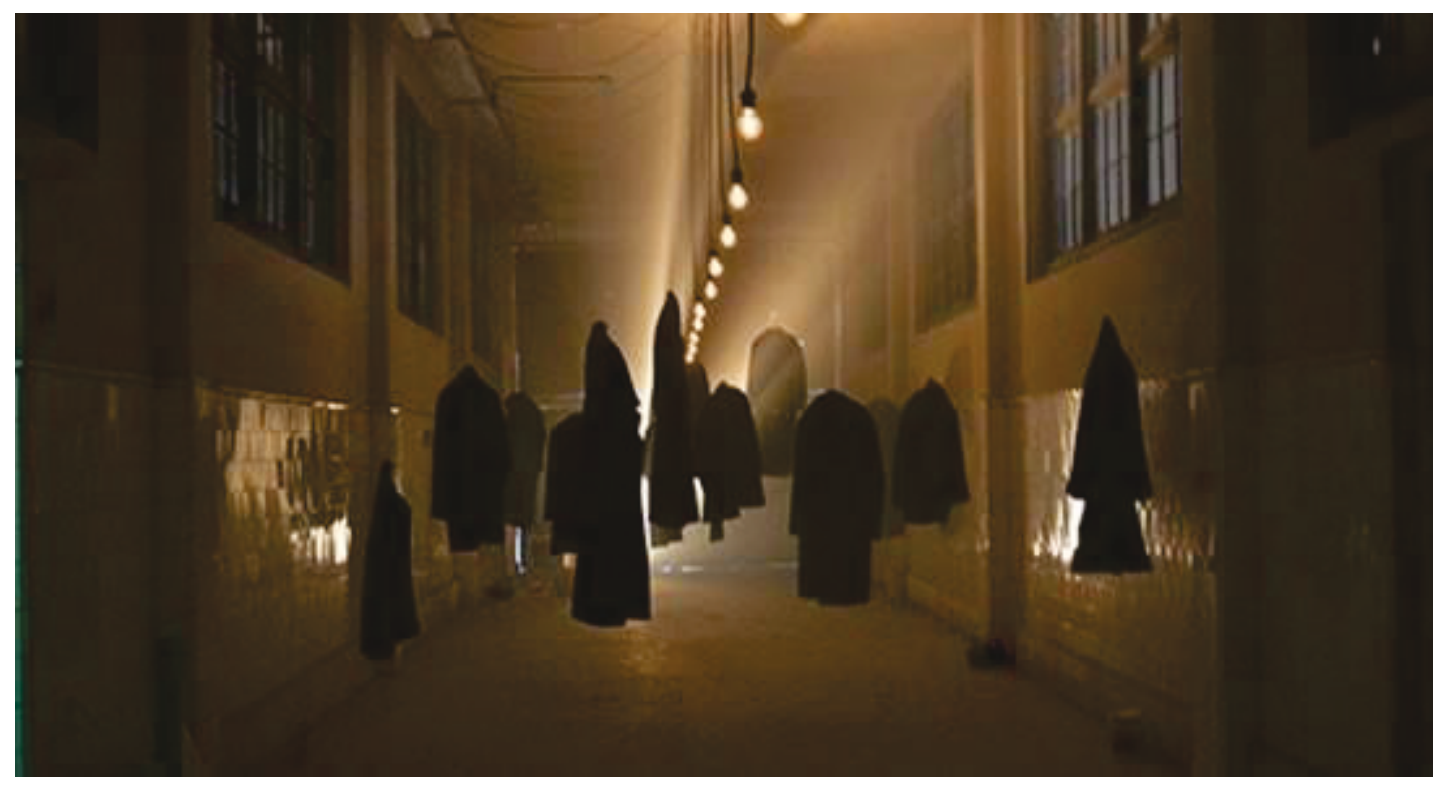

Figura 11: Vista parcial de Migrantes, de Christian Boltanski. Hotel de Inmigrantes, CABA, 2012

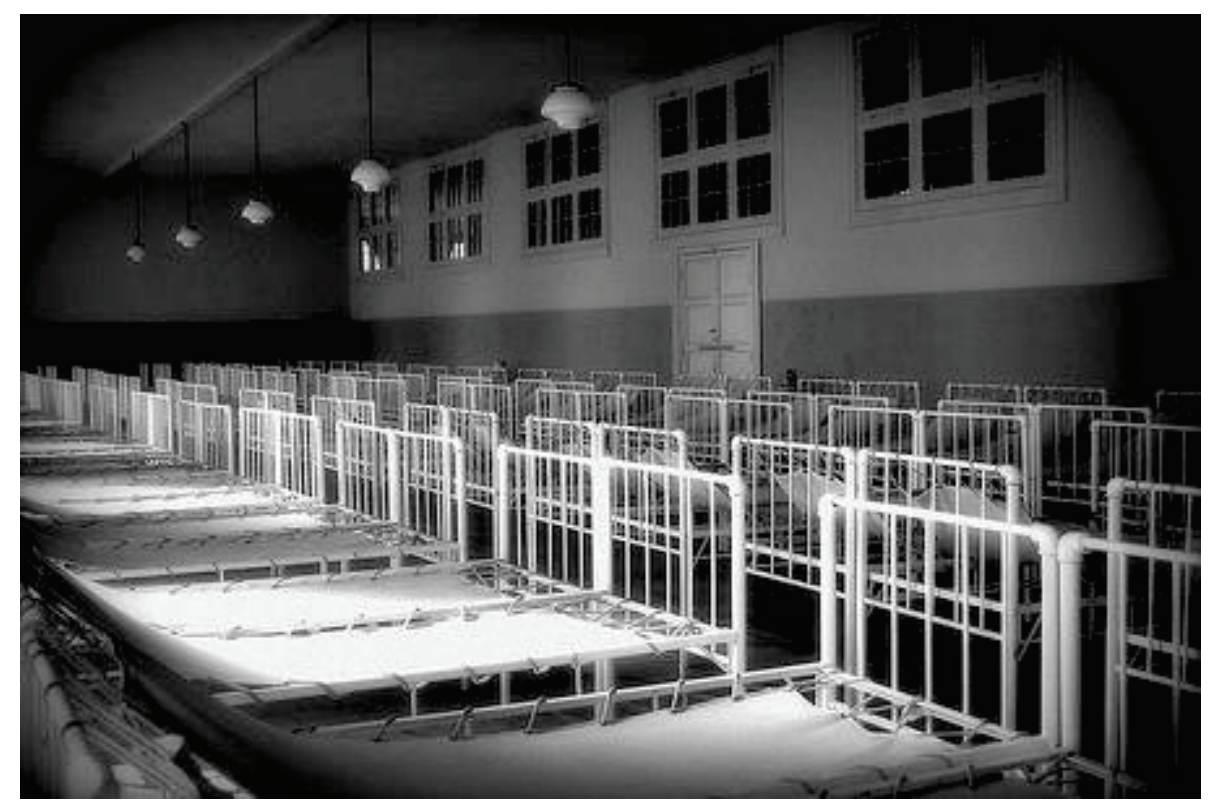

Figura 12: Hotel de Inmigrantes de Buenos Aires. Imagen de archivo

La total vinculación de la propuesta con el lugar para el que ha sido pensada, imposibilita su traslado en idénticas condiciones, por cuanto el emplazamiento proporciona gran parte del contenido y la experiencia única del lugar. Si bien Boltanski prevé la itinerancia de muchas de sus obras (algunas de las cuales, incluso, forman parte de Migrantes, como "Sombras", de 1985), considera que las piezas deben adaptarse y transformarse cada vez que son exhibidas. Sólo de 
esta forma -entiende-, el trabajo contextual del arte, como catalizador para la emoción, puede resistir el tiempo y sobrevivir al artista (Grenier, 2009).

La obra de Boltanski podría ser pensada también a la luz del concepto de instalación total, formulado por Ilya Kabakov, que refiere a una forma particular de percibir el arte, que combina la inmersión física con la psicológica.

La Instalación Total exigiría de una completa absorción psicológica, por la que la lectura simbólica de objetos ensamblados en el espacio, procurara en el espectador una cadena de libres asociaciones, conscientes e inconscientes a un mismo tiempo (Sánchez Argilés, 2009).

De este modo, la instalación articularía asociaciones complejas, analogías culturales o cotidianas y memorias personales. $Y$ junto con el condicionamiento topológico, este particular modelo de recepción profundizaría en la idea de una experiencia singular e irrepetible, que escruta en este caso en la memoria individual, familiar y colectiva. El propio Boltanski vincula al arte con este devenir entre lo personal y lo colectivo cuando señala que:

Un artista sólo puede hablar de lo que está entre él y los otros. Se habla siempre de una especie de experiencia común. Muchas experiencias humanas son comunes, todos hemos perdido a un ser querido, todos tenemos igual miedo frente a la muerte, un anhelo de armonía, la búsqueda de Dios, el sexo, el asombro frente a la belleza de la naturaleza. Hay cinco o seis temas tratados por los artistas desde el inicio de los tiempos. Lo más importante es que cada uno de nosotros es único, pero al mismo tiempo siempre, rápidamente llega el olvido (Boltanski en Weschler, 2012).

Más adelante volveremos en profundidad sobre este caso paradigmático de instalación inmersiva, en las que resultan fundamentales sus implicancias como obra de sitio específico.

Como ya señaláramos, aunque sigan produciéndose este tipo de obras para unos emplazamientos particulares, en las últimas décadas parecen haberse multiplicado los posibles modos de interrelación que una instalación puede presentar con el espacio que la aloja. Aunque habitualmente se conserve la relación de reciprocidad entre obra y lugar antes mencionada, proliferan las propuestas itinerantes, que carecen de una localización preestablecida, aunque 
solicitan un espacio equipado con características precisas (Sánchez Argilés, 2009: 29). Miwon Know (2002) refiere a un deslizamiento desde la localización fija e inamovible postulada en los setenta por las obras de sitio específico, hacia un vector discursivo, no fijo, fluido y virtual: las obra de concepto específico o de sitio orientado (Figuras 12 y 13). Estas admiten la relocalización en la medida que su significación no depende ya del lugar de su emplazamiento sino de su propio discurso narrativo y conceptual (Kwon, 2002: 46)

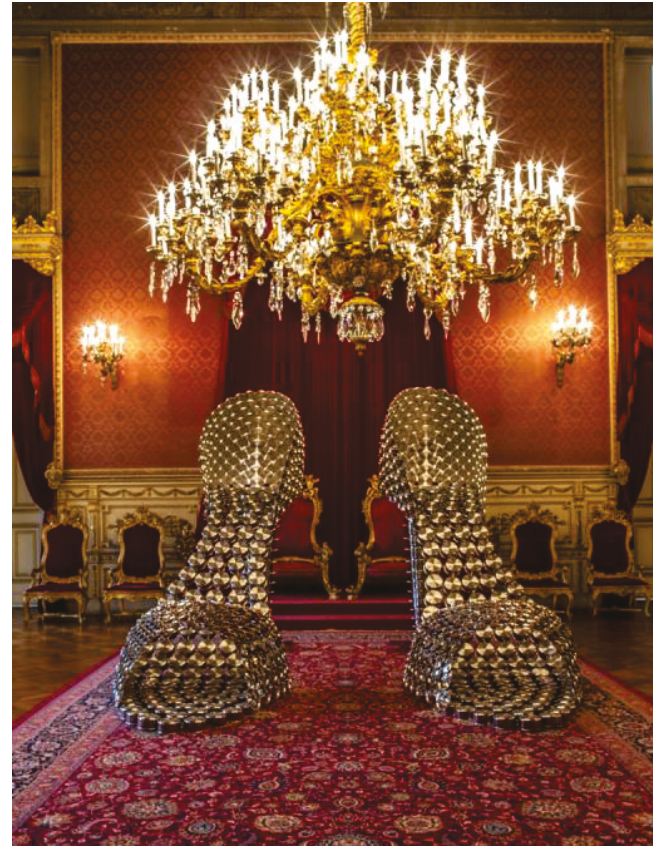

Fig. 12 Vista de Marilyn, de Joana Vasconcelos Palacio Nacional de Ajuda - Lisboa (2013)

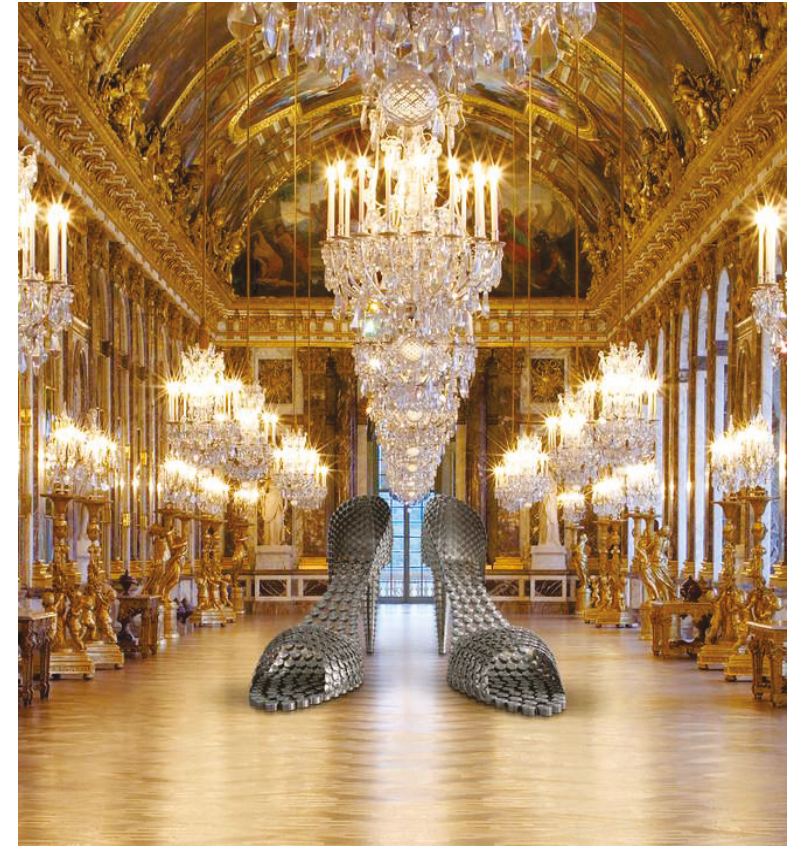

Fig. 13 Vista de Marilyn, de Joana Vasconcelos Palacio de Versalles - Paris (2012)

En Marilyn, la artista portuguesa Joana Vasconcelos refiere a la figura ausente de Marilyn Monroe, construyendo un par de zapatos de tacón de escala monumental $(2 x-297 \times 155 \times 410 \mathrm{~cm})$ mediante la acumulación de brillantes cacerolas de acero inoxidable y sus respectivas tapas. La obra propone una revisión de lo femenino a la luz de las prácticas del mundo contemporáneo: el recurso de las cacerolas remite a un rol tradicionalmente asignado a la mujer: el de la esfera doméstica. Pero la autora lo propone como sustrato constructivo de un símbolo de la belleza y la elegancia occidental, dando cuenta - de esta forma - de la tensión que subyace entre modelos de lo femenino en las esferas pública y privada. 
La artista se apropia y subvierte los objetos y las realidades cotidianas, descontextualizándolos y recontextualizándolos, creando un fuerte contraste con la decoración palaciega de los espacios en que la obra cobra sentido, y que obedecen al criterio de sitio orientado propuesto por Know: ambos hacen presente la fastuosidad de las cortes europeas y configuran un marco que alimenta la densidad de conceptos como lujo, realeza, distinción; y que nos permiten revivir historias que habitan esa tensión, como la de Cenicienta, arquetipo de la fregona devenida princesa.

\subsection{La instalación como dispositivo.}

Como señaláramos anteriormente, las instalaciones han sido tradicionalmente pensadas como una forma particular de exponer, que interpela a un espacio artístico dado, al que toma como objeto de su reflexión. Un abordaje de la instalación como dispositivo reclama la actualización de algunas perspectivas teóricas acerca de ambas nociones y sus posibles cruces:

Por un lado, Boris Groys (2008: 7) se refiere a la instalación como el producto de una selección y concatenación de opciones, una lógica de inclusiones y de exclusiones, que hace que determinadas imágenes y objetos de la vida cotidiana se reinscriban en un espacio diferenciado: un espacio de encuentro, de puesta en relación; presente por definición, supeditado a la impronta de un acontecer aquí y ahora.

En tanto, Jean Pierre Meunier (1999), define al dispositivo comunicacional como una red de sentidos interrelacionados, un ordenamiento de medios en función de un fin. Este ordenamiento particular configura una entidad compleja en la que la enunciación tiene lugar, "lugar en que operan los intercambios discursivos; lugar donde se torna posible el emplazamiento social de los discursos" (Buján, 2008: 51).

Tanto la instalación como el dispositivo suponen la articulación de dos instancias indisociables: una técnica y otra social. La primera establece la particular configuración material, una manera singular y distintiva de obrar el espacio; y la segunda, promovida por las relaciones intersubjetivas que funda, la situación en 
la que éstas se inscriben (Buján, 2008: 50). En el plano material, el dispositivo presenta una particular configuración espacio temporal, así como una cierta composición semiótica (Meunier: 1999: 4). En él se reconoce una pluralidad de dominios simultáneos, que involucran aspectos espaciales, temporales, afectivos, semióticos, relacionales y cognitivos. Podemos así llegar a establecer algunas asociaciones con la práctica de la instalación, en la que confluyen dimensiones equivalentes: una espacial, asociada a la directa apropiación y articulación de un espacio; una temporal, en tanto implica una renegociación permanente del tiempo de contemplación/aprehensión, entre artista y espectador/usuario (Groys, 2008: 7); una relacional, un modo particular de vincularse con el mundo, equiparable con la lógica de inclusión y exclusión a la que alude Groys - y una semiótica, en tanto responde a una necesidad de construir sentido.

De esta manera se hace posible interpretar a la instalación como dispositivo tanto al interior de sí misma - en términos de una concatenación de elementos materiales que persiguen un fin, enunciativo y simbólico -, como también en tanto elemento constitutivo de un dispositivo macro: el del espacio en que se expone, el de la propia institución artística.

\subsection{Apuntes para una definición descentrada.}

Si bien lo expuesto hasta aquí ha permitido dar cuenta de algunos ejes que atraviesan la práctica en forma recurrente, también ha llevado a constatar que ninguna de las características enunciadas parece - en sí misma - dotar de especificidad a la instalación. Por eso nuestro acercamiento al fenómeno no podrá realizarse a partir de una definición concreta, sino que responderá más bien, como su propia formación, al resultado de una serie de confluencias, propósitos y realizaciones concretas.

En Los límites de la instalación, Mónica Sánchez Argilés (2004) propone acudir a fórmulas que acepten la contradicción, la paradoja y la convivencia de configuraciones diversas en un mismo sistema: si en la práctica los artistas producen obras que se ajustan a unos parámetros tácitamente consensuados de instalación, éstos nunca serán precisos ni inamovible, sino más bien una suma de 
características que resultan inclasificables con la aplicación de categorías tradicionales.

Partiendo de este reconocimiento, circunscribiremos nuestro abordaje a aquellas prácticas que privilegian por sobre otras características la experiencia del espectador, a partir de su inmersión física en la obra. Para este propósito será de utilidad la definición de Therry de Duve (2009), quien entiende a la instalación como "el establecimiento de un conjunto singular de relaciones espaciales entre el objeto y el espacio arquitectónico que fuerza al espectador a verse como parte de la situación creada". Este enfoque se vincula a la idea de escenografía que quiere ser habitada, propuesta por Suderburg (Suderburg, 2000: 33), y a la mirada de Ilya Kabakov, cuando señala que el lector "tiene que pensar en un escenario de teatro donde el espectador puede subir durante el entreacto" (Kabakov, 1995: 26).

También para Claire Bishop (2001), la característica distintiva del arte de instalación respecto de los medios tradicionales está constituida por este lugar central que en ellas ocupa el espectador. Por eso alude a la presencia de un sujeto corporeizado, que ingresa físicamente en la obra para experimentarla con todos sus sentidos y es por eso interpelado por la obra de un modo directo e incisivo. Aquí, y a diferencia de lo que ocurre con otro tipo de producciones artísticas, parecen diluirse las fronteras entre obra y espectador, devenido visitante. Por eso la experiencia de las obras inmersivas, supeditadas a la impronta de un acontecer aquí y ahora, resulta considerablemente diferente de la que se puede tener con la pintura o escultura tradicionales. En lugar de representar texturas, espacios y luz, las instalaciones presentan estos elementos de modo directo para que el público los experimente. Por eso involucra tanto la situación del espacio expositivo como la experiencia del espectador, que es guiado a reflexionar sobre su propia vivencia y su proceso de percepción. 


\section{CAPÍTULO 2: Acerca de los orígenes reconocidos. Del minimalismo a la instalación.}




\subsection{En torno al surgimiento de categorías conceptuales para la comprensión y análisis de las instalaciones}

El término instalación fue utilizado por primera vez por el minimalista Dan Flavin, hacia 1968, para designar sus obras espaciales con tubos fluorescentes agrupados en formas de figuras simples, que daban un carácter inmaterial al espacio expositivo que los contenía. Se suele considerar por eso que las situaciones ambientales llevadas a cabo por los artistas minimalistas fueron las primeras experiencias del arte del environment; obras pensadas y realizadas en función del espacio (galerías, museos, centros urbanos, etc.) que, como tales, conferían un carácter de experiencia única e irrepetible al hecho de exponer y a aquello que se exponía (Guash, 2000: 29)

En su libro La originalidad de la Vanguardia y otros mitos modernos, Rosalind Krauss presenta la idea de la evolución del objeto escultórico en el campo expandido, que problematiza las coordenadas en las que se encuentra suspendida en la contemporaneidad la noción de escultura. La categoría de campo flexibiliza sus contornos permitiendo dar cabida tanto al arte cinético y la performance, como al arte del entorno y la instalación.

De este modo, el campo proporciona al artista un conjunto finito pero ampliado de posiciones relacionadas que emplear y explorar, así como una organización de la obra que no está dictada por las condiciones de un medio en particular (Krauss, 1985: 302).

Es posible que la lectura expansiva y lineal que ofrece Krauss, junto a la naturaleza frecuentemente tridimensional de la instalación, hayan sido factores determinantes en la tendencia a interpretar a ésta última como la evolución lógica del objeto escultórico (Sánchez Argilés, 2009: 34). Javier Maderuelo también entiende a la instalación como forma escultórica expandida, pero más específicamente originada en un cambio de sensibilidad que experimentó la escultura minimalista al deshacerse del pedestal y aproximarse al espacio del espectador, "rompiendo así la barrera, saltando del escenario al patio de butacas, donde se hallan los objetos de uso común" (Maderuelo, 1990: 76)

Sin embargo, el único soporte de la instalación es el espacio mismo - que es, según Groys (2008) la condición más general del mundo material, en la que 
conviven el resto de los medios artísticos -. En consecuencia, nada parece privilegiar la evolución escultórica por sobre la de otros medios y disciplinas (pictórico, arquitectónico, teatral, entre otros) en relación al origen de la instalación. Más bien podríamos pensar que fueron los valores sobre los que se construyó el mundo occidental de posguerra los que dieron lugar a la emergencia de circunstancias y condiciones contingentes que favorecieron la proliferación de significados híbridos, a menudo procedentes de disciplinas solapadas (Sánchez Argilés, 2009: 34). Por eso, sin profundizar en su posible génesis, podríamos decir que la instalación contemporánea se fue delineando como resultado de una trama compleja de transformaciones y desplazamientos conceptuales y formales que, hacia los años sesenta, gestaron un panorama ampliado de los espacios del arte.

La instalación, como disciplina híbrida, está configurada por diversas referencias; incluye arquitectura y performance en su parentesco, y también contiene diversidad de caminos de las artes visuales contemporáneas. Al cruzar las fronteras entre las distintas disciplinas, la instalación es capaz de cuestionar su autonomía individual, su autoridad y por último su historia y relevancia en el contexto contemporáneo (De Oliveira, 1994: 7).

El vínculo, comúnmente aceptado, que relaciona al minimalismo con la práctica de la instalación, invita a revisar los aportes y debates teóricos que se gestaron en torno a él. Y no tanto como posible precedente histórico, sino en relación a algunos conceptos que, esgrimidos en esos debates, se han vuelto fundamentales para el análisis y la comprensión de las instalaciones.

Los objetos minimalistas marcan un punto de inflexión entre el arte de la vanguardia y el de la postvanguardia: no sólo constituyen "el último eslabón de una cadena de depuración y búsqueda de la esencia de lo artístico propia del vanguardismo" (Pérez Carreño, 2003: 14), sino que también inauguran un proceso de pérdida del valor material del objeto y la paralela y creciente relevancia de sus condiciones de exhibición.

Para Francisca Pérez Carreño, la noción de arte minimal ha contribuido a organizar temporalmente el arte de los sesenta. Aunque por entonces aún no estaba institucionalizado el término instalación - y se utilizaban, como ya señaláramos, otros tales como ambientes, lugares e incluso esculturas-, la defensa de esta forma 
de hacer arte, que introducía nuevos procedimientos y materiales (muchos de ellos producidos industrialmente), evidenciaba una estrategia opositora a los criterios modernistas de Clement Greenberg, por entonces el más influyente crítico de arte. Siguiendo el argumento reductivo de la vanguardia, la escultura minimalista tendió a la supresión de lo que consideraba accesorio, a través de la eliminación de la figuración y el pedestal y el cuestionamiento de otras convenciones tales como la verticalidad y la unidad física del objeto. En el plano semántico, prescindió de todo contenido representativo y expresivo, lo que la convertiría, para sus detractores, en un arte vacío. (Pérez Carreño, 2003: 114)

El minimalismo podría considerarse, entonces, el último episodio en la historia de las vanguardias: tanto histórica como conceptualmente, se asumió como una superación crítica de los movimientos anteriores y un último momento en la tarea autorreflexiva de la modernidad, de búsqueda de la autonomía y de las condiciones mínimas y específicas de lo artístico. Sus prácticas contribuyeron a disolver la separación entre las esferas del arte y la vida (antigua reivindicación de la vanguardia histórica). Al mismo tiempo, significaron un avance en la incorporación y aprovechamiento de los nuevos medios en el campo artístico, que contribuyeron a consolidar una nueva concepción -pretendidamente anti-idealista- del arte.

No obstante, la clasificación del minimalismo como movimiento de vanguardia fue cuestionada desde el primero momento en más de un sentido. Contra la progresiva erosión de la "pureza de la obra", se alzaron voces reivindicadoras del arte formalista como el único verdaderamente moderno; entre ellas, la de los críticos Clement Greenberg y su discípulo Michael Fried, para quienes los minimalistas resultaban enemigos y corruptores no sólo de la modernidad tardía sino también del arte en sí mismo (Guash, 2000: 29). Francisca Pérez Carreño señala que:

Para Greenberg o [Michael] Fried suponía precisamente el fin de la vanguardia entendida como la evolución crítica y en búsqueda de su autonomía de los diversos géneros artísticos. El minimal era, desde un punto de vista general, incompatible con una consideración idealista del arte y de la obra de arte como creadora de una experiencia estética sui generis. (Pérez Carreño, 2003:115) 
En cambio los historiadores postformalistas ligados a la revista October, liderados por Rosalind Krauss, defendieron a partir de los ochenta la idea de que el arte minimal constituye la última corriente realmente vanguardista del arte contemporáneo, de la que se nutren las tendencias más valiosas del arte de los últimos tiempos, entre ellas la instalación. Si bien reconocen su carácter crítico de la estética idealista, interpretan que esta lectura se realiza en el marco de la propia vanguardia.

El movimiento minimalista introdujo conceptos teóricos cruciales para la práctica y análisis de las instalaciones, principalmente en relación a la incorporación del espacio circundante en la experiencia estética del espectador, y por lo tanto, centrales para entender tanto la relación espectador-obra como obra-entorno (Sánchez Argilés, 2009:37). Algunos minimalistas, como Robert Morris, se interesaron por cómo el espectador percibía e interactuaba con la obra de arte:

Se trataba de una confrontación con el cuerpo. Se trataba de la idea de que el objeto retrocede en importancia. De la participación en una experiencia completa que incluye el objeto, tu cuerpo, el espacio y el tiempo de tu experiencia. (Kaye, 2000:27)

Es con este movimiento que se comienza a entender a la obra como elemento generador del espacio, alejada de la idea de escultura autónoma. Su carácter, habitualmente modular y repetitivo, determinó una ocupación distributiva del espacio, e incidió favorablemente en la relación entre los elementos que formaban parte de la misma. Así, cada una de las partes - en relación con otras - podía experimentarse como totalidad (Sánchez Argilés, 2009: 37), y de este modo fue afianzándose la idea de lo ambiental, hasta convertirse en uno de los debates centrales que ocuparon a artistas, teóricos y críticos. Ana María Guash (2000) señala, que, al margen de los distintos usos que se dieron al término ambiente (environment), éste siempre implicó la existencia de un espacio envolvente, a través del cual el espectador podía trasladarse y desenvolverse. En El arte último del siglo $X X$, manifiesta que

Tal vez la nota fundamental es la extensión y expansión transitable de la obra en el espacio real. No se trata de una reproducción, sino de la instauración de una realidad en una situación espacial. Este espacio (...) afecta con una intensidad compleja a la actividad sensorial del espectador. Este se verá envuelto en un movimiento de participación e 
impulsado a un comportamiento exploratorio respecto al espacio que le rodea y a los objetos que se sitúan en él. (Guash, 2000: 173)

De este modo la práctica minimalista fue adquiriendo un carácter procesual y temporal que no sólo afectó la relación entre el creador y la obra, sino a las relaciones entre la obra, el espectador y el espacio circundante. La obra, como presencia en relación al espacio que la contenía, se hacía indisociable de la experiencia del espectador, arrancado ya del cómodo papel del "voyeur" y devenido parte constitutiva y estructural.

\subsection{Michael Fried: la condena de lo teatral.}

La noción de lo ambiental dio paso a la de lo teatral, adjetivo que, con intención peyorativa, utilizó el crítico Michael Fried en su ensayo "Arte y Objetualidad", publicado en 1967 en la revista Artforum. Fried utilizó el término teatralidad para denostar el trabajo temporal e interactivo de los minimalistas Donald Judd y Robert Morris, inaugurando un debate que ha generado múltiples análisis y refutaciones a lo largo del resto del siglo XX. Según Fried, un arte que dependía cada vez más de su situación en el espacio y en el tiempo era un arte teatral, y como tal, atentaba contra la autonomía de la auténtica obra moderna, la cual debía manifestarse independientemente de quien la contemplase.

A su criterio, los minimalistas no lograban trascender el nivel de lo literal; entendía que el afán por investigar los elementos mínimos de la escultura los había conducido a la producción de meros objetos, que no alcanzaban a crear una experiencia estética válida que permitiera percibirlos como obra de arte (es decir, no sólo como materia, sino espiritualizado y cargado de sentido). Es por eso que el minimalismo - al que denomina despectivamente movimiento literalista - no formaría parte de la historia del arte moderno en sentido estricto. Para Fried como para Greenberg, la inclusión de la temporalidad suponía la violación de las categorías puras de la pintura y la escultura, ya que de esta forma la obra de arte se convertía en generadora de una situación que envolvía al espectador en la experiencia del tiempo y el espacio. Por eso manifiesta: 
La sensibilidad literalista es teatral porque (...) está relacionada con las actuales circunstancias en las que el espectador se encuentra con la obra literalista. Morris lo hace explícito. Mientras que en el arte anterior "lo que se consigue con la obra se localiza estrictamente dentro (de ella)", la experiencia que se tiene del arte literalista lo es de un objeto en una situación - una situación que, prácticamente por definición, incluye al espectador. (Fried, 1998: 179)

Los escritos de Greenberg y Fried fijaron los términos de la discusión sobre los problemas que el minimalismo presenta para la estética moderna y vanguardista. Las categorías de literalidad y teatralidad fueron adoptadas por defensores y detractores como señas de identidad del nuevo movimiento. Para los modernistas la falta de manipulación artística del material, de sintaxis, la carencia de contenido y el efectismo del minimal relegaban a sus obras a un lugar de pseudo arte (Pérez Carreño, 2003: 15). Asimismo la creciente relevancia de las condiciones de exhibición, su dependencia del espacio y de la institución, evidenciaba el carácter meramente aparente de su artisticidad.

Para Fried, la práctica artística que surge de la reducción minimalista se desplaza así hacia relaciones externas, esencialmente variables, de las cuales el espectador es parte receptiva y actor. En ese marco, se encuentra inmerso en lo que designa como "teatralidad", por oposición a la absorción en un principio de contemplación que lo conduce hacia una experiencia de plenitud. (Fried, 1998:177) ${ }^{5}$. Uno de los motivos en los que percibía la literalidad de los objetos minimal era en su intervención material y concreta en el espacio del espectador.

Se dice que algo tiene presencia cuando exige al espectador que lo tenga en cuenta, que lo tome en serio - y cuando el cumplimiento de dicha exigencia consiste, simplemente, en tener conciencia de la obra y (...) actuar en consecuencia (...) el espectador es consciente de que guarda una relación indeterminada, abierta - y no rigurosa- como sujeto con el impasible objeto que está en la pared o en el suelo (Fried, 1998:180)

\footnotetext{
5 Es de interés señalar que, años antes de que Fried formulara este concepto, algunas obras pop habían comenzado a aproximarse a la misma idea, convirtiéndose en tridimensionales y proyectándose dentro del espacio real del espectador. Un ejemplo de lo expuesto lo constituye Roxy's (1960-1961) de E. Kienholz. Si bien estos ambientes actualizaban el espacio ficticio del cuadro dentro de la galería, habitualmente prohibían la circulación del visitante, a diferencia de las instalaciones minimalistas que podían ser penetradas.
} 
Esa situación distanciada, indeterminada, abierta que supone la presencia del objeto es equiparada por Fried con la que produce la presencia de otra persona, por lo que entiende que la experiencia de tropezar inesperadamente con objetos literalistas puede ser algo fuertemente inquietante, al menos por un momento. La literalidad no significaba que el objeto pasara desapercibido sino, por el contrario, que llamara la atención sobre sí mismo, determinando una experiencia directa pero inapropiada sobre el espectador: por eso el arte minimal era "teatrero", artificioso, teatral en mal sentido (Pérez Carreño, 2003: 196).

Para Fried estos objetos eran teatrales porque carecían de entidad artística, descansando su éxito en la "puesta en escena". De esta manera, "ofrecían a la audiencia una especie de experiencia perceptual realzada" (Fried, 1998: 40), una mera búsqueda de efecto. Así, las producciones minimal serían teatrales porque no conseguirían la unidad formal en sí mismas, con independencia de su inscripción espacial; por el contrario, requerirían de la puesta en escena, de la colocación en un espacio (arquitectónico-escénico) compartido con los cuerpos de los espectadores. Como el teatro, reclamarían siempre una audiencia, sin la cual no llegarían a constituirse como obra: "Parece que depende del espectador, está incompleta sin él, le ha estado esperando..." (Fried, 1998: 140). Claro que toda obra de arte exige una participación activa del espectador; pero "de lo que se acusa al minimal es de que se convierta en arte sólo porque produce un efecto en el espectador" (Pérez Carreño, 2003: 201). Ese efecto, según Fried, sería causado por medio del antropomorfismo, es decir, por el uso instrumental del cuerpo humano:

El literalismo teatraliza el cuerpo, lo pone interminablemente sobre un escenario, lo hace extraño y opaco a sí mismo, lo vacía, mata su expresividad, le niega el sentido de finitud $y$ en un sentido su humanidad (Fried, 1998: 42)

Pérez Carreño entiende que, de algún modo, Fried acusa a los objetos minimal de poseer aura, de tener cierto poder de devolver la mirada. Porque aunque seriados (y, en ese sentido, desauratizados), su aquí y ahora, su carácter único - y no sus propiedades estéticas-, llevarían al espectador a participar en la revelación de una presencia. En cuanto a su posible teatralidad, no serían sus cualidades 
estéticas o expresivas, sino su lugar en el espacio, la relación con el espectador o su tamaño, lo que las habría de convertir en obra de arte.

Fried no cuestiona que la experiencia del objeto escultórico incluya una dimensión corporal (la propia del espectador, y la de los objetos), sino que el espectador se convierta en cuerpo consciente de sí mismo, pero como pura exterioridad.

No desaparece en la experiencia estética, sino que, como en un escenario, se ve viendo, no puede dejar de sentir que la obra está hecha para él, y que sus movimientos han sido previstos y son inevitables. El espectador, que no puede evitar considerar la obra en relación a su propio cuerpo, abandona el estado de olvido de sí que exigía el concepto de interpretación moderno (Pérez Carreño, 2003: 203). ${ }^{6}$

\subsection{Hibridación y contingencia.}

En los años ochenta, Hal Foster reivindica el arte minimal, al que las posiciones postmodernas tildaban de intelectualoide, frio y aburrido. En El retorno de lo real. La vanguardia a finales de siglo (1996), retoma el debate en torno a la experiencia del minimalismo, defendiendo su seriedad vanguardista. A pesar de su institucionalización, el minimal representa para él la resistencia en el seno de la institución artística a la fetichización del objeto y la ideologización de la cultura, por lo que, junto a Rosalind Krauss, lo defiende como el auténtico continuador de los principios radicales de la vanguardia, señalándolo como una nueva apertura en el campo del arte, que contribuye a un deslizamiento de paradigma hacia las prácticas posmodernas (Foster, 1996: 40).

Para Foster, el minimalismo constituye la arremetida más eficaz contra el "vanguardismo formalista", representado en la crítica y la historia del arte de los sesenta por Greenberg y Fried. Entiende que Greenberg, como defensor de la autonomía artística, veía en el minimal un tipo de arte que, al vincularse a una determinada política institucional que le daba cabida, invalidaba sus eventuales

\footnotetext{
6 En cambio, para Rosalind Krauss, la conciencia corporal del espectador en el minimalismo manifiesta la superación de una concepción exclusivamente visual de la interpretación artística, en favor de una experiencia de tipo fenomenológico.
} 
poderes críticos, antiacadémicos y novedosos, prerrogativas éstas de la auténtica vanguardia. $^{7}$

A diferencia de Fried, Foster sostiene que el minimal no sienta sus bases en la sola idea de reducción, sino más bien en el desplazamiento hacia prácticas caracterizadas por mezclas e hibridaciones que remiten a la idea de teatralidad. Considera que no se trata sólo de un arte del espacio sino un arte del tiempo que se redefine en términos de lugar, siendo ésta particularidad la que lo aproxima al teatro. $^{8}$ Entiende que el minimalismo privilegia una experiencia de tipo fenomenológico que trata de superar la dualidad metafísica de sujeto y objeto y "así, lejos del idealismo (...) complica la pureza de la concepción con la contingencia de la percepción, del cuerpo en un espacio y un tiempo particulares" (Foster, 1996: 44). En la transformación que lleva a la escultura a abandonar el pedestal y resituarse entre los objetos, el espectador es devuelto al aquí y ahora, por lo que

en vez de escudriñar la superficie a fin de establecer un mapa topográfico de las propiedades de su medio, a lo que se ve impelido [el espectador] es a explorar las consecuencias perceptuales de una intervención particular en un lugar dado. (Foster, 1996:42)

Por eso sostiene que el minimalismo tiende más a lo epistemológico que a lo ontológico, puesto que se basa más en condicionamientos perceptuales que en una esencia formal o un ser categórico. Al preocuparse por la dimensión temporal y la recepción en el arte procesual, el minimalismo cuestiona el orden de la

\footnotetext{
7 Greenberg califica al minimal de arte pequeño burgués disfrazado de arte avanzado, por abandonar las convenciones de los géneros en las que a su juicio residía la especificad de lo artístico. Entendía que las rupturas vanguardistas debían, realizarse en el marco convencional del lenguaje propio de cada forma artística; por eso su visión de la historia del arte moderno omitía las vanguardias transgresoras - tales como el surrealismo y el dadaísmo -, en favor de la línea abstracta. Así, la falta de calidad del arte minimal, se fundaba para Greemberg no tanto en una carencia de complejidad formal o composición, sino en que sus características formales no sean "sentidas", "inspiradas", o correctas.

${ }^{8}$ El tema del lugar fue asumiendo cada vez más importancia y se estableció como una constante en el desarrollo del arte de los setenta en todos los movimientos artísticos tanto de Europa como de América (povera, conceptual, y land art, entre otros)
} 
estética moderna, estrictamente espacial. Y al mismo tiempo anuncia un nuevo interés por el cuerpo, la presencia y la percepción, y por lo tanto, por el sujeto.

Asimismo, el autor en una relectura de la obra de Michael Fried, entiende que para éste la amenaza minimalista consiste en "un intento de desplazar el arte tardomoderno por medio de una lectura literal que confunde la presentidad trascendental del arte con la presencia mundana de las cosas". De allí que Fried crea que el objeto minimalista es equiparable a un personaje disfrazado, una presencia que produce una situación, que, aunque provocativa, es extrínseca al arte visual.

Las hipótesis principales del pensamiento friediano están, para Foster, contenidas en la idea del minimalismo como práctica "incurablemente teatral", siendo que "el teatro es ahora la negación del arte". Estas afirmaciones ocultan la revelación sobre la naturaleza convencional del arte que llevarán a sus sucesores neovanguardistas a transgredir sus límites institucionales, negar su autonomía formal y anunciar su final:

Para Fried como para Greenberg, tal vanguardismo (...) lejos de ser una superación dialéctica del arte en la vida (...) obtiene el literalismo de un acontecimiento y objeto sin marco "tal como ocurre, tal como meramente es". Fried llama a ese literalismo minimalista "teatral" porque implica el tiempo mundano, una propiedad que considera inadecuada para el arte visual. Así, aunque el minimalismo no amenace la autonomía institucional del arte, el viejo orden ilustrado de las artes (las artes temporales frente a las espaciales) es puesto en peligro. (Foster, 1996: 55).

\subsection{La contradicción entre especificidad y presencia.}

En 1992 Georges Didi-Huberman, en una línea antropológica y psicoanalítica, aborda en "Lo que vemos, lo que nos mira", una reflexión sobre el concepto de presencia, y revisa el debate en torno al minimalismo en la escena artística contemporánea.

Huberman construye dos categorías de sujeto según su relación directa con los objetos del arte: el hombre de la creencia y el hombre de la tautología. En la 
actitud tautológica señala una voluntad expresa por no ir más allá de los límites de lo que se ve, empeñada en afirmar que un volumen no es otra cosa más que él mismo (Didi-Huberman, 1992: 31). En esta pretensión de borrar toda evocación simbólica y atenerse únicamente a lo visible, este sujeto de la tautología parece corporeizarse en torno al arte conceptual, y especialmente al minimal, llegando a constituir el fundamento y el modelo del sujeto del arte contemporáneo. ${ }^{9}$

Lo habrá hecho todo, ese hombre de la tautología, para recusar las latencias del objeto, afirmando como un triunfo la identidad manifiesta - mínima, tautológica - de ese objeto mismo: "Este objeto que veo es lo que veo, un punto, eso es todo". Lo habrá hecho todo, en consecuencia, para impugnar la temporalidad del objeto, el trabajo del tiempo o de la metamorfosis en el objeto, el trabajo de la memoria - o del asedio - en la mirada (...) lo habrá hecho todo para recusar el aura del objeto... (Didi-Huberman, 1992: 21)

Ese es el espíritu con que artistas como Donald Judd, Robert Morris y Dan Flavin, entre otros - en un intento de llegar al grado cero de significación - dieron auge a esa corriente de objetos específicos y auto-referentes. Objetos simples. Objetos tautológicos, que se proponen eliminar toda ilusión y exigen ser vistos sólo por lo que son, por lo que dejan ver, privados de toda imaginería o elemento de creencia. Objetos que no ocultan nada, que no se ofrecen como simulacro, sino que simplemente se exponen para ser vistos, sin construir espacios ni tiempo más allá de si mismos. Didi-Huberman los describe además como objetos estables, en la medida que se los construye como insensibles a la marca del tiempo y de cualquier posible proceso de metamorfosis que pudiera determinar un cambio de sentido:

Nada de interioridad, por lo tanto. Nada de latencia. Nada, tampoco, de ese "recogimiento" o esa "reserva de la que nos habló Heidegger al cuestionar el sentido de la obra de arte. Nada de tiempo, en consecuencia, nada de ser, únicamente un objeto, un "específico" objeto. Nada de recogimiento, por lo tanto, nada de misterio. Nada de aura. (Didi-Huberman, 1992: 34)

\footnotetext{
9 Por el contrario, la actitud de la creencia, encuentra en la experiencia de ver un "algo Otro", que la nutre de un sentido teleológico y metafísico. (Didi-Huberman, 1992: 23)
} 
Sin embargo, pone en cuestión lo que denomina el dilema de lo visible, señalando que los enunciados tautológicos no logran sostenerse. Por un lado reconoce que los objetos minimalistas no representan nada como imagen, al suprimir todo proceso ilusionista o antropomorfo. Refiere, en concreto, al paralelepípedo de Donald Judd, señalando que

...no representa nada en la medida misma en que no vuelve a poner en juego ninguna presencia supuesta en otra parte - cosa que en mayor o menor grado intenta toda obra de arte figurativa o simbólica, y toda obra de arte ligada en mayor o menor grado al mundo de la creencia(...) se da allí, frente a nosotros, como específico en su propia presencia. (Didi-Huberman, 1992: 35)

Pero observa que la apelación a la cualidad de ser, la evidencia que se asigna al objeto, es tan abrupta, fuerte y específica como la del propio sujeto, puesto que se inscribe en el mundo fenomenológico de la experiencia.

La fuerza del objeto minimalista fue pensada en términos fatalmente intersubjetivos (...) el objeto se pensó aquí como "específico", abrupto, fuerte, indominable y desconcertante, en la medida misma en que, frente a su espectador, se convertía insensiblemente en una especie de sujeto (Didi-Huberman, 1992: 37)

Huberman recupera y profundiza en este sentido la perspectiva de Robert Morris, para quien el objeto minimal era un término: pero no en el sentido de un punto sin retorno, sino un elemento diferencial en una relación, una variable en una situación, y por tanto un "cuasi-sujeto", equivalente a una definición del actor o doble. ${ }^{10}$ Es decir que, paradójicamente, tras intentar eliminar toda ilusión, el objeto minimalista deviene obra formada por una red de relaciones. Esta paradoja - sostiene - no es sólo teórica sino también visualmente perceptible, y se encarna en la contradicción entre "especificidad" y "presencia". Por eso sigue su rastro en el debate entre Donald Judd y Michael Fried: donde por un lado, la pretensión de especificidad formal condujo a la literalidad de los volúmenes y - a través de ella - a la supuesta transparencia semiótica de una concepción tautológica de la visión; y por otro, la vocación por la presencia, la puesta en situación del objeto con respecto al sujeto, condujo a una pretendida opacidad

10 Refiere en concreto a la obra/ performance de R. Morris de 1961: una columna erguida de madera contrachapada de 2.5 metros de alto por 0.60 de ancho, en un escenario, que, pasados tres minutos cae; tres minutos más tarde, cae el telón. Muchos críticos afirman que una presencia teatral análoga perdura en la producción posterior de Moris, a pesar de que haber abandonado el escenario y comenzado a compartir el espacio estético del espectador. 
propia de una experiencia intersubjetiva. Este análisis - indica Huberman conduce a Fried a diagnosticar acerca de la naturaleza fundamentalmente antropomórfica del objeto minimal, cuestión que se halla en la base del uso que hace de la categoría de lo teatral en las artes visuales, denunciando el ilusionismo teatral a través del que los objetos minimalistas imponen al espectador "su insoportable presencia"

Allí donde Judd reivindicaba un arte no relacional por no ser expresionista, Fried por su parte no verá más que una pura y simple relación puesta en escena entre objetos y miradas. Allí donde Judd afirmaba la estabilidad y la inmediatez temporal de sus "objetos específicos", Fried ya no verá sino una temporalización compleja e infinita, penosa y contradictoria, dramatizada e impura (DidiHuberman, 1992: 44)

Lo expuesto hasta aquí evidencia el papel fundamental que ejercieron los objetos minimalistas en el cambio de relación de la obra con el espacio circundante y en la valorización de la experiencia singular del espectador. Desde entonces, fue haciéndose innegable que el espacio en que se inscribe una obra contribuye a gestarla y definirla, en tanto que esta - a su vez - determina una particular percepción de dicho espacio. Las situaciones ambientales llevadas a cabo por los artistas minimalistas fueron las primeras obras pensadas y realizadas en función del espacio (galerías, museos, centros urbanos, etc) que, como tales, conferían un carácter de experiencia única e irrepetible al hecho de exponer y a aquello que se exponía. ${ }^{11}$

11 Sin embargo, Graham Coulter-Smith cuestiona esta perspectiva. Lo hace a través de la observación de tres características que parecen emerger del análisis histórico de las instalaciones: la intención de proponer una participación más directa entre el espectador - devenido usuario - y la obra; la presentación de fragmentos que el público debe explorar, y reunir, para activar; y la estrategia de la escultura expandida de deconstruir el concepto tradicional de la obra de arte valiosa, mediante el uso de objetos y materiales encontrados. (Coulter Smith, 2009: 14)

Estos tres aspectos la aproximan al análisis del arte radical vanguardista de los sesenta que realiza Peter Bürger en Teoría de la Vanguardia: Bürger identifica algunas características sobre la tercera corriente en el siglo XX (que él denomina, imprecisamente, vanguardia, iniciada por Duchamp, el Dadaísmo y el Surrealismo), que podrían resumirse en tres aspectos principales: en primer lugar, la deconstrucción del concepto tradicional de obra de arte valiosa mediante el uso de materiales pobres y objetos encontrados; en segundo lugar, un deseo de integrar el arte en la vida cotidiana que implica un posicionamiento hacia el elitismo del arte institucionalizado; en tercer lugar, la creación de textos fragmentados mediante estrategias como el montaje y el azar que animan al lector a involucrarse en el proceso creativo. 
En ese marco, la inclusión del espectador no sólo comprende a la obra en sí, sino también a la dimensión espacial y a su propia actividad en relación a ambas. Aunque de momento no supone una experimentación corporal tan directa, veremos cómo, más adelante, esta posición se revitaliza en el caso de las instalaciones inmersivas.

Si Fried entendía que con la teatralidad la escultura veía enturbiado su sentido específico, Rosalind Krauss en cambio, interpreta que esta categoría le proporciona una ampliación enriquecedora del contexto del espectador, sirviendo como herramienta para la disolución y reconstrucción de sus márgenes (Krauss, 1977:237). Por eso advierte que el de teatralidad es un concepto paraguas (Krauss, 2002:203), bajo el que pueden agruparse una multiplicidad de estilos y prácticas heterogéneas, como la que nos ocupa.

Por tanto resulta de particular interés observar cómo, y con qué fines estéticos, la teatralidad, la presencia, y algunas otras categorías vinculadas al espacio escénico y al tiempo dramático, son recuperadas, apropiadas y resignificadas en el terreno del arte contemporáneo, al punto de revertir el sentido peyorativo que se asignó al término teatral, hasta transformarse en adjetivación fundante de las prácticas artísticas contemporáneas.

Este análisis de Bürger sugiere, para Coulter Smith, que los aspectos significativos evidentes en la historia de las instalaciones de Claire Bishop pueden rastrearse antes de la década de los sesenta, a principios del S XX, lo que habilitaría una nueva genealogía posible para estas prácticas. 


\section{CAPÍtULO 3: Poéticas en cruce. La pregunta por lo teatral.}




\subsection{Teatralidad $y$ artes visuales: una frontera imprecisa.}

A lo largo del siglo $\mathrm{XX}$, lo teatral ha contribuido en forma decisiva a configurar notables cambio en la percepción de lo que entendemos como práctica artística, transformándose en un calificativo que excede ampliamente los límites del campo escénico.

Como veíamos en el capítulo anterior, a mediados de los años sesenta se produce un cambio de paradigma estético, que permite la reintroducción de lo narrativo, la figuración y la teatralidad, como aspectos reprimidos en las artes visuales del período moderno. Algunos artistas ligados al arte conceptual reaccionaron entonces ante la literalidad minimalista, convirtiendo al escenario teatral en una zona de experimentación. A través de sus aportes se vio notablemente ampliado el alcance de los dispositivos del modelo teatral, conformando un núcleo del que irradiaban los fundamentos de lo contemporáneo: la simultaneidad de acción y percepción y el desdibujamiento de roles entre el actor y el espectador, entre otros.

Ileana Diéguez Caballero (2007) sostiene que en dicho período el campo de lo teatral fue restando peso al discurso verbal y abandonando el principio de la mímesis, en favor de la preponderancia de lo corporal y lo vivencial. Allí donde el enfoque literario tradicional proponía una estructura fija que se ofrecía para su interpretación, la mirada teatral contemporánea abordaría la idea de cultura como proceso y de realidad como un hacer continuo, que sólo funciona en tanto se está produciendo y está siendo percibida (Cornago, 2009: 4) ) $^{12}$

Así como las vanguardias abrazaron la idea de la "obra de arte total", y concibieron al teatro como su espacio de realización, en esta segunda mitad del siglo XX, en cambio, se fueron radicalizando los aspectos que promovían la hibridación de la escena teatral con las artes visuales, los nuevos medios y las acciones

\footnotetext{
12 Óscar Cornago (2009) considera que el elemento clave para intentar una lectura de la teatralidad radica en la mirada del otro, que funciona como detonante. Si bien todo fenómeno estético - y por ende toda obra de arte- supone la intencionalidad de construir pensando en el posible efecto que ha de causar en su receptor, la teatralidad supera esa instancia, al carecer de existencia por fuera del momento en que se concreta la acción de mirar y ser mirado. Por eso a este momento inaugural Cornago suma otros dos: la naturaleza procesual del hecho dramático, que sólo tiene realidad en tanto está funcionando; y el fenómeno de la representación, es decir, "la dinámica de engaño o fingimiento que se va a desarrollar: el actor interpretando el personaje" (Cornago, 2009: 5-6)
} 
performativas (Diéguez, 2007: 14). Las artes visuales adoptaron entonces una noción de teatralidad ampliada, entendida como recuperación del cuerpo, sus experiencias y sus huellas para la concreción de una obra abierta.

Es así que podemos observar cómo la idea de teatralidad salta a otros campos, lo que va a dificultar progresivamente su delimitación. Por eso la posvanguardia se declararía como un tiempo de liminalidad del teatro con otras artes, de transposición de umbrales poéticos y frontera entre los lenguajes.

A través de este diálogo permanente con el teatro, los medios artísticos tradicionales de las artes visuales se han ido redefiniendo, y a la vez han surgido y se han consolidado prácticas que - como la instalación - suponen nuevos modos de abordar la teatralidad y lo performativo (Sánchez, 2010: 11). Por eso la reflexión sobre la influencia del lenguaje teatral resulta imprescindible para comprender la naturaleza híbrida de lo artístico, y proporciona un nuevo prisma para abordar un sinnúmero de propuestas y actitudes artísticas contemporáneas, como la que nos ocupa.

Los estudios sobre teatralidad suelen dividirse entre los que postulan una comprensión amplia de este fenómeno - no restringida al campo de lo escénico - y los que lo piensan como privativo del medio teatral. Para Jorge Dubatti durante los últimos veinte años y en consonancia con el avance de la mediatización, el estatuto problemático de lo teatral se ha visto acentuado a causa de una transteatralización, es decir, la teatralización total de la experiencia. En este sentido, Oscar Cornago señala que:

El fenómeno de las grandes urbes, el surgimiento de las masas provocado por la revolución industrial, la sociedad de consumo y la revolución electrónica de los medios de comunicación, ha potenciado los niveles de teatralidad. El número de escenarios donde actuar, en los que mirar y ser visto, ha conocido un abrumador aumento con la proliferación de monitores, cámaras y otros espacios públicos al alcance de todos. El derecho a la representación ha conocido una suerte de paradójica democratización (Cornago, 2009: 3)

En este contexto, es preciso revisar las especificidades del lenguaje teatral para poder intentar definir luego miradas transversales e integradoras, que posibiliten pensar la complejidad de los fenómenos considerados escénicos. Ileana Diéguez 
insiste en pensar la teatralidad como práctica liminal, remarcando su condición de suceso y su capacidad de insertarse en el tejido de acontecimientos vitales y sociales, que desbordan el campo teatral e incluso el estético, pero generando un lenguaje que convoca la mirada y la reflexión desde el campo artístico (Diéguez, 2007:10-12).

Este argumento ha sido sin duda de máxima relevancia a la hora de abordar una reflexión sobre la cualidad escénica de la instalación y sobre su posible naturaleza teatral. Por eso, y a efectos de consolidar los estudios de la liminalidad y la interrelación del teatro con otras artes, resulta insoslayable la pregunta sobre la especificidad de lo teatral, es decir sobre los rasgos singulares que constituyen su esencia.

\subsection{El teatro como acontecimiento.}

Etimológicamente, el término teatro, remite precisamente a la intuición de ver, haciendo referencia tanto a la visión como a la expectación. Porque Theatron en griego significa no sólo lugar donde se asiste a un espectáculo, lugar de una asamblea, sino también lugar donde se es visto, donde uno se hace ver; vinculándose desde esta perspectiva a la idea de figurar, estar expuesto, mostrar y mostrarse.

Según el Diccionario Griego Español, Thea es la acción de mirar, de contemplar; y - a la vez -, lo digno de ser mirado; el lugar de la expectación; la vista de una cosa - objeto de contemplación. Estos y otros términos afines remarcan la solidaridad entre ver, mirar y ser visto, articulando el vínculo entre lo mirado y quien lo ve. Por eso el teatro se define como "el lugar adonde se va a mirar para ver, donde se enseña y se aprende a mirar y como el acto mismo de la visión" (Breyer, 2005: 23).

Para Jorge Dubatti, el punto de partida del teatro es la "institución ancestral del convivio", entendiéndose por tal la práctica de socialización, el encuentro de cuerpos en unas coordenadas precisas de espacio y tiempo que posibilita el 
intercambio humano directo, imposible de ser sustituido por mediaciones técnicas. A propósito de esto señala que:

Sin encuentro de presencias no hay teatro, de allí que se pueda reconocer en el convivio el principio -en el doble sentido de fundamento y punto de partida- de la teatralidad. (Dubatti en Ábalo, 2008: 88)

El acontecimiento convivial es experiencia vital intransferible, y por eso está atravesado por la cualidad imprevisible de lo real ("el actor puede olvidarse la letra y hasta morir en escena", ejemplifica el autor). Eso lo hace eminentemente temporal y volátil, sujeto a la fluidez y el cambio propios de la vida cotidiana, aspectos que obstaculizan la posibilidad de su repetición absoluta. Por eso exige a los sentidos - en especial la vista y el oído -, una extremada disponibilidad a la captación del otro, captación permanentemente mutante, ante la posibilidad cierta de perder aquello que no se repetirá. Por las razones expuestas Dubatti caracteriza al convivio como el imperio por excelencia de lo aurático. Porque ese encuentro de presencias no es perdurable, sino que dura lo que el convivio: es también, en consecuencia, imperio de lo efímero, de una experiencia que sucede e inmediatamente se desvanece y se torna irrecuperable:

Si el teatro sólo acontece en la dimensión aurática de la presencia corporal espiritual de artistas, técnicos y público -conjunción que inicialmente es humana y sólo a posteriori reconocerá la distribución de roles de trabajo-, luego se disuelve y se pierde. Por su efímera dimensión convivial, el teatro -como la experiencia vital- se consume en el momento de su producción. (Dubatti en Ábalo, 2008: 89-90)

En el acontecimiento del teatro, al convivio sigue un acontecimiento de lenguaje. Este consiste en la instauración de un orden ontológico otro y en la construcción de un universo paralelo, formulado en términos poéticos. Esta nueva dimensión que se genera, determina una amplificación del mundo, siendo este aspecto el que distingue al teatro de otras formas de espectacularidad a las que Dubatti define como "parateatrales". El acontecimiento poético desencadena - a su vez un último momento, que acaba por constituir al teatro como tal: el de la conformación del espacio del espectador.

Algunas de las ideas expuestas, que redefinen lo teatral en nuevos términos, generan resonancias en torno a nuestra búsqueda actual, y parecen proponer 
analogías prometedoras. En tanto intersección en que confluyen la experiencia perceptiva del espacio y del objeto por parte de un sujeto inmerso que experimenta, la instalación aparece también como circunstancial encuentro de presencias en coordenadas efímeras de espacio y de tiempo; así como el teatro, la instalación está sujeta a la imprevisibilidad de lo real, y a la contingencia que caracteriza al acontecimiento. ${ }^{13}$ Por lo mismo, ambos comparten la condición de fugacidad y la dificultad de su documentación; puesto que - paradójicamente -, pese a la condición reproductible de buena parte de los elementos que la componen (pensemos por ejemplo en los sobretodos de Migrantes), y a pesar asimismo de la itinerancia a la que frecuentemente las obras se ven sometidas, la experiencia estética de la instalación, íntimamente conectada a un tiempo y un espacio particulares, y condicionada por una activación polisensorial del espectador, imposibilita cualquier tipo de reproducción, reclamando más bien la condición de una experiencia única del aquí y ahora que nos permite parangonarla con la noción de acontecimiento convivial.

También en la instalación, luego de la confluencia de los cuerpos en un tiempo y un espacio particulares sigue la instauración de un nuevo orden, de naturaleza poética y ficcional. Sin embargo, encontramos en la constitución del espacio del espectador importantes elementos diferenciadores.

El teatro siempre tiene lugar en un espacio delimitado por la separación entre la mirada del público y el objeto observado o escena. El universo poético creado a partir de procesos de semiotización, ficcionalización, referencia y función estética genera un espacio al que el espectador no tiene acceso, un sitio de veda. Se trata de un espacio escindido de lo real, un espacio de virtualidad y fantasía: el origen de la escena. Por eso el espectador de teatro se constituye como tal precisamente a partir de la limitación que supone la imposibilidad de acceder a ese espacio diferenciado, y que será redefinido en cada tipo de representación.

Para que exista el teatro, afirma Silvia Debona (2003), debe conservarse esa separación, deben permanecer inmunes el espacio de lo real y el espacio de la

\footnotetext{
13 En sentido filosófico todo acontecimiento supone la perseverancia de una alteración en la que confluyen y se ponen en relación, en un sentido contingente y paradójico, múltiples y heterogéneos mecanismos azarosos, singulares y productivos de experiencias y subjetividades.
} 
ficción, aun en aquellos casos en que se invita al público a invadir el espacio escenográfico ${ }^{14}$. Cuando esa delimitación se altera, para posibilitar la interacción de un espectador que pueda llegar a modificar el flujo de la acción, éste pierde su condición de tal para asumir el rol de actor, borrando de este modo el límite entre lo real y lo ficcional.

Sin embargo, el lugar de la expectación puede modificarse intencionalmente en forma provisoria, como parte de un recurso poético: el espectador puede salir, de este modo, de dicho espacio para ingresar en el campo del acontecimiento poético. Pero el espacio de expectación nunca desaparece por completo. Sobre este particular, Jorge Dubatti ejemplifica:

Puede quedar delegado a un único espectador mientras el resto de la platea participa "tomada" por el acontecimiento poético, pero dicho espectador es el que garantiza que el teatro no se transforme en parateatro. No hay teatro sin función espectatorial, sin espacio de veda, sin separación óntica entre espectáculo y espectador (Dubatti en Ábalos, 2008: 95)

La pérdida de la dimensión espectatorial determina, para el autor, que el teatro se convierte en práctica espectacular de parateatralidad, en la que el observador comparte el mismo nivel de realidad con el acontecimiento observado, y el arte se fusiona con la vida. En este tipo de manifestaciones - como sucede con algunos espectáculos de intensa participación festiva -, la expectación es desplazada por la participación, por lo que el espectador frente a la mirada ajena aparece como parte integrante del mismo espectáculo.

Esta última situación es la que presenta más puntos de contacto con la práctica de la instalación, donde la observación tiene lugar en un espacio compartido. En las instalaciones - que no sólo comprenden los objetos sino el espacio que los separa y la propia corporalidad del espectador -, desaparece la diferencia estricta entre interior y exterior, así como la del sujeto en tanto espectador respecto de su función como componente indisociable de la obra. Esta transgresión de las categorizaciones está en el mismo germen de la práctica de la instalación, y en ese marco, la percepción momentánea y fugaz adquiere su valor por sobre la

\footnotetext{
${ }^{14}$ El área de veda o de actuación puede estructurarse aún por medio del sólo gesto o incluso por la sola mirada del actor, determinando la aparición de un espacio sagrado e inviolable, en el que cobra sentido la distancia de la que habla Walter Benjamin.
} 
concepción de la obra autosuficiente que postulaba la estética tradicional. (Rodríguez Cunnil, 1999: 13)

\subsection{Territorios mixtos: espacios del teatro - espacios de la instalación.}

Tal como lo expresa Patrice Pavis (1980), la noción de espacio se aplica en el teatro a aspectos muy diversos del texto y de la representación, dando lugar a un escalonamiento múltiple, que se organiza en torno a dos grandes ejes: en el exterior un espacio mundanal o periférico; luego un espacio del espectáculo o ámbito escénico.

En relación a lo anterior, se distinguen - en principio - el espacio dramático abstracto y el espacio escénico. El primero es aquel que construye el texto y se actualiza en la imaginación del lector. A diferencia del anterior, el segundo es un sitio concretamente perceptible, de índole real, por donde se mueven los actores. Su naturaleza es doble, puesto que no sólo muestra lo que concretamente existe, sino que remite también a lo que simboliza. Es, por lo tanto, a la vez espacio significativo y representante. El significante es el lugar concreto situado ante mí, tal y como lo percibo (ej. una gran habitación, un cuartucho, ejemplifica el autor); el significado -en tanto- es el espacio sugerido por el significante, su sentido: esta gran habitación es el apartamento del príncipe; este cuartucho es la celda de Fausto.

El tercer espacio a considerar es el espacio escenográfico, que comprende tanto el espacio escénico como el espacio de los espectadores, y que se define por la relación entre ambos, es decir, por la forma en que la sala percibe la escena y por la forma en que la escena se manifiesta al público ${ }^{15}$. $\mathrm{Y}$ finalmente un cuarto, el

\footnotetext{
${ }^{15}$ La escenografía es, literalmente, una escritura en el espacio tridimensional, que entra en relación con una dimensión temporal. El escenario teatral contemporáneo ya no supone sólo la materialización de indicaciones escénicas problemáticas, sino que rechaza jugar un papel de "simple figuración" respecto de un texto preexistente y determinante. (Breyer, 2005: 53). En la actualidad la escenografía concibe su función no ya como como ilustración ideal y unívoca del texto dramático, sino como dispositivo propicio para enriquecer (y no ya para ilustrar) el texto y la acción humana, para construir una situación de enunciación ( $y$ no ya un lugar fijo), y para situar el sentido de la puesta en escena en el intercambio entre un espacio y un texto (Pavis, 1990: 173).
} 
espacio gestual, creado por la evolución de los actores en el escenario. (Pavis, 1980: 188).

En una etapa temprana del desarrollo de este trabajo surgió como interrogante la posibilidad de establecer una correspondencia entre el espacio escenográfico (que articula la escena y la platea) y el espacio de la instalación. Esta intuición pronto pareció confirmarse, en tanto la inmersión física del espectador en la instalación da lugar a una suerte de superposición de las dimensiones de acción y expectación, a través de una performance individual que determina que la construcción de sentido e incluso - en algunos casos - una suerte de narratividad, anclen precisamente en ese cuerpo presente.

Ilya Kabakov explica que quien se acerca a la práctica de la instalación debe necesariamente pensar en "un escenario de teatro donde el espectador puede subir durante el entreacto", por lo que la instalación podría ser entendida como el lugar donde se ha producido, se produce o puede producirse un acontecimiento (Kabakov, 1995: 26).

La historia del teatro puede dar cuenta de múltiples precedentes en el campo de las obras inmersivas. Particularmente con los cambios de paradigma del siglo XX, el hecho escénico vuelve a ubicarse al filo de lo ritual, de lo ceremonial, recuperando su condición originaria (Debona, 2003: 6). Esta se remonta a la tragedia griega, que tiene su origen en los cultos dionisíacos y el ditirambo. Estos ritos se realizaban en lugares destinados especialmente para la representación en los que la comunidad participaba activamente, ya que existía un total conocimiento de lo que debía acontecer y del papel a desarrollar por cada miembro. Este pleno conocimiento del código de la representación era lo que generaba una sensación de pertenencia y de intervención en lo sagrado, a pesar de la eliminación de toda propuesta personal o azarosa. Paulatinamente, la conservación del rito fue quedando en manos de unos pocos (probablemente como producto del progresivo aumento de la complejidad del código) generando la separación de papeles entre "actores" y "espectadores", hecho que propiciaría una participación distanciada del ritual, y conformaría los orígenes del teatro occidental. 
En el siglo XX, el intento de sumergir al espectador en la escena reaparece en la búsqueda de reconciliación con ese ritual. En "El teatro y su doble", Antonin Artaud intenta, en palabras de Susan Sontag, "remediar la escisión entre lenguaje y carne" (Sontag, 1987). A partir de su acercamiento al teatro balinés, Artaud reniega del teatro occidental acusándolo de rendir un excesivo homenaje al autor y por lo tanto a la palabra ${ }^{16}$. "No se trata de suprimir la palabra... sino de modificar su posición, y sobre todo de reducir su ámbito". Por eso propone modificar la tradicional relación actor-espectador preconizando un espectáculo giratorio en el cual la separación de escena-sala, propia del teatro a la italiana, quede superada. Esta modificación del espacio generaría una percepción distinta del hecho teatral al propiciar una mayor cercanía al ámbito escénico y por lo tanto una comunicación más directa entre el actor y el espectador. El espacio teatral en X (como ha sido tipificada la relación actor-espectador propuesta por Artaud) es centrífugo: ubica al público en el centro y la escena en la periferia; de este modo, transforma a todo el espacio en escena y procura una mayor integración del público, al que sumerge en la acción, lo que la ha valido la denominación de teatro total.

El teatro de Artaud participa de las cualidades del espacio inmersivo, de los que podemos encontrar antecedentes ya en los ritos mágicos prehistóricos, o en la Edad Media, donde el espacio escénico posee una estructura procesional, y se conforma como una sucesión en el tiempo de unidades espaciales. Aquí la percepción de dichas unidades no se daba en forma simultánea, sino sucesiva, siendo el espectador el encargado de recomponer mentalmente el espacio $y$, en consecuencia, sentirse envuelto en él.

\footnotetext{
${ }^{16}$ Artaud rechaza el teatro que se realiza en Occidente en su época señalando que este ha caído en una serie de convencionalismos que han destruido su carácter mítico y místico, reduciéndolo a un teatro "psicológico" basado en diálogos en los que las palabras se han fosilizado perdiendo su naturaleza sagrada de signos mágicos. Las palabras, a su juicio, han terminado por domina a un teatro en el que la puesta en escena está subordinada al diálogo y se presenta como una suerte de accesorio. Así, el teatro ha perdido su fuerza, su capacidad de impactar al espectador hasta dejarlo sin aliento. Lo psicológico ha asfixiado a lo primario y primigenio, el análisis ha sustituido a lo sensorial, la explicación a la sensación.
} 
En el marco de los Movimientos de Vanguardia que se desarrollaran desde mediados del siglo XIX hasta mediados del XX, se producen múltiples aportes en este sentido:

En sus investigaciones escenográficas, Adolph Appia abordó la problemática del escenario como instrumento, proponiendo una nueva valoración del decorado como elemento y del espacio escénico como lugar en que la acción teatral se desarrolla. Para Appia, el espacio escénico no es ya sólo el polígono determinado por la línea de implantación escenográfica, sino una totalidad técnico teórica en la que evoluciona el trabajo del actor. Es por tanto un espacio que se amplía hasta abarcar las relaciones actor/público, espectador/espectáculo; hasta convertirse en la entidad espacial neutra en la que se dispone el lugar de la acción escénica y unas determinadas relaciones con los espectadores que la contemplan, configurando una identidad espacial vital, que es percibida a través del trabajo del actor.

Por su parte, Mayerhold señala que:

Todo espectáculo por crear en estos días debe de aspirar a que la sala participe en la acción que se desarrolla sobre el escenario. Al organizar sus espectáculos, el dramaturgo y los técnicos no deben contar solo con los actores y la maquinaria sino también con la sala, invitada a ayudarles y a completar su obra. Producimos conscientemente espectáculos inacabados, porque las correcciones más importantes deben ser hechas por los espectadores. Estos espectáculos se consumarán, de una a otra representación, por los esfuerzos conjugados entre actores y público. (Ceballos, 1986: 36)

Alrededor de 1906-1907, Meyerhold lee "La escena del futuro" de Georg Fuchs, texto que lo impactaría vivamente y que resulta decisivo en su producción posterior. En él, Fuchs hacía un Ilamado "a la restauración del teatro como ritual festivo comprometiendo por igual a actores y espectadores en una experiencia común que revelara el significado universal de su existencia personal" (citado en Debona, 2003: 8). El autor sostenía que la obra no tiene vida sino como experiencia compartida, ya que en virtud de sus orígenes, el actor y el espectador, el escenario y la sala, no se oponen el uno al otro, sino que constituyen una unidad. 
Tanto la ruptura del espacio ilusionista propuesto por Appia en la escenografia y el espacio escénico, como la reflexión de Meyerhold desde sus puestas en escena son coincidentes con el cambio de paradigma formal que sucede en las artes plásticas, en las que de la estructuración mimética de gran parte del arte y la literatura Occidental transitan hacia la construcción de las mismas.

La posterior evolución de estas perspectivas - con Piscator y el Living Theatre con su anarquismo ritual, entre otros - llega con motivaciones y lenguajes diversos hasta nuestros días con los llamados espacios inmersivos tecnológicos o espectáculos parateatrales, en los que desde el momento mismo en que el espectador ingresa a la sala, abandona el rol de observador para involucrarse como participante de un acontecimiento, con el que comparte el mismo nivel de realidad, en una situación muy próxima a la que ha dado origen al presente proyecto.

\subsection{El cuerpo en acto: representación y performatividad.}

La especulación teórica en torno al trabajo del actor y su importancia en el marco de los procesos de creación es otro de los tópicos centrales de la teoría teatral del siglo XX.

Como mencionamos en el comienzo de este capítulo, en el marco de las vanguardias históricas se va gestando una redefinición del teatro en tanto puesta en escena de un texto dramático. Este radical cambio de perspectiva hace foco en la figura del actor como creador, y no ya como mero intérprete de un texto dado: Stanislavsky, Meyerhold, Grotowsky, Barba, el Living Theatre, entre otros, ponen al actor en el centro de sus debates, llegando a establecer que es en la relación particular entre éste y el espectador donde se establece la comunión perceptual, directa y convivial que constituye la base del hecho teatral.

La reflexión en torno al trabajo del actor lleva a considerar un doble camino, según se entienda la práctica teatral como representación o como performance. Ambos caminos o modos de abordar la actuación - condicionantes de la práctica 
escénica en su conjunto -, son diferenciados por Ricardo Bartís cuando señala que

Hay un teatro dominante, que es el teatro representativo (...) Un teatro con personajes y límites precisos tanto físicos como emocionales en relación con un modelo de lo real, de lo dado como lo real. El relato preexiste al cuerpo del actor... entonces el trabajo del actor consiste en reproducir representar o traer al espacio ese elemento previo a él. (...) Hay otro teatro, que deviene más del teatro del actor (...), no representativo, no tiene una legalidad estilística sino que funda un territorio poético en la presunción de que va a crear un instante, un instante privilegiado por el cual se va a producir un acontecimiento (Bartís, 2003: 118-120).

Daniela Martin (2010) analiza la perspectiva de Bartís, señalando la diferenciación que establece entre un teatro de representación, y un teatro de actuación. En el primero, el actor interviene como intérprete, dando lugar a un tipo de teatralidad representacional, en tanto los procedimientos de construcción se asientan en un modelo mimético, a través del que se intensifica el aspecto ficcional del hecho escénico. En el segundo, de índole más performática, tanto la actuación como la idea de teatralidad suponen la acentuación del presente escénico. De esta manera, el happening y la performance, así como algunas otras prácticas que tensionan el eje realidad - ficción, indagan en procedimientos que involucran la anulación del aspecto representacional y enfatizan las propia circunstancia de enunciación y producción de sentido. (Martin, 2010: 3-6), aspecto al que aludiremos luego al referir a la dimensión performativa de la instalación.

Queda así diferenciado un tipo de teatro en el cual el texto otorga el marco ineludible para el desempeño del actor-intérprete, y otro en el que la acción deviene dramaturgia, a partir de la construcción permanentemente efímera que determina el cuerpo en movimiento. En este último caso el actor es artífice permanente de la obra, perspectiva que inaugura la reflexión en torno a su rol como creador de ficción, así como de una poética particular: esta se produce en tanto su cuerpo configura un proceso siempre cambiante, que genera relato desde el mismo suceder escénico.

Más allá del tipo de teatro que consideremos, el cuerpo del actor interviene materialmente sobre la ficción que construye, en tanto todo gesto, palabra o tono 
son elementos de la construcción de un discurso. Por eso ese cuerpo, al estar en situación de exposición, se transforma ante la certeza del ser mirado. En esos casos, la mostración adquiere la función de estimulación permanente, frente a la cual el actor responde, tanto instintiva como técnicamente.

Oscar Cornago afirma que "la escena contemporánea ha convertido esta relación en un espacio de tensiones desde el que se trata de recuperar el cuerpo como un modo de pensar y estar frente al otro..." (Cornago, 2008: 54). El autor refiere de este modo a la relevancia que la presencia del otro supone como elemento que tensiona e incide sobre la construcción dramatúrgica del actor, especialmente en el de tipo performático, en el que el sentido se produce y se consume en el mismo instante, obligando al actor a asumir la organización instantánea del sentido. Esto ha llevado a considerar un pensamiento escénico en acto ${ }^{17}$, fundado en la operatoria consciente del actor para construir discurso, operando simultáneamente sobre la escena y sobre sí mismo.

\subsection{La instalación y su dimensión teatral}

El aspecto teatral de la instalación puede rastrear sus antecedentes a través de la noción modernista de Gesamtkunstwrek, la obra de arte total. Gesamtkunstwrek es el ideal de Wagner de una síntesis creativa para unir arte y música en el marco visual del escenario operático ${ }^{18}$. Si bien hay importantes diferencias conceptuales entre la instalación y la obra de arte total, ambas parecen presentar como denominador común el establecimiento de nexos fluidos con la idea de teatralidad, comprendida como concientización del proceso de vida y nuestra

\footnotetext{
${ }^{17}$ La dramaturgia del actor refiere a la metodología de trabajo que intenta situarse como una postura ideológica 'alternativa' al trabajo canónico sobre el texto teatral. De este modo, la relación entre escena y texto tensiona el vínculo entre la acción y la palabra que la interviene transformándola en un elemento dotado de una dimensión cuerpo, de una vitalidad expresiva y de una sustancia espacial (Argüello Pitt, citado en Martin, 2010: 5).

${ }^{18}$ La obra total se puede equiparar con el teatro total, con esa creación artística que debe ser (según la Bauhaus) "...un conjunto orgánico de redes de relaciones entre iluminación, espacio, superficie, movimiento, sonido y ser humano con todas las posibilidades de variaciones y combinaciones de estos diversos elementos" (Pavis, 1980: 224)
} 
parte en éste, más que como referencia al dominio del género dramático (De Oliveira y otros, 1994: 76)

El concepto de obra de arte total conjuga la actividad propuesta por diversas artes para conseguir una sola. Surgido en el contexto del romanticismo alemán y popularizado sobre todo por la ópera wagneriana, persiguió la alianza de todas las artes para conseguir un objetivo común. Wagner manifestaba que allí donde una de las artes alcanzaba sus límites infranqueables, comenzaba rápidamente, con la más rigurosa exactitud, la esfera de acción de otra. Consecuentemente, por la unión íntima de ambas, se expresaría con la claridad más satisfactoria lo que no eran capaces de expresar cada una de ellas por separado (Wagner, 1987: 15-16) ${ }^{19}$.

La convivencia simultánea de las artes para la consecución de otra, de carácter superior, se pensaba en relación con un tiempo determinado: ya no se trataba de un arte de objetos inamovibles e imperecederos, sino de una intención de captar la atención del espectador en un momento concreto; no una estructura unitaria y única, sino diversa en su totalidad.

Esta condición, así como la yuxtaposición de diversas artes para convertirse en otra de entidad superior - una especie de una unidad orgánica en la que es posible verificar la existencia de diferentes componentes- es, por tanto, una de las características que heredará la instalación. De alguna manera, podemos entender que esta última recupera esa búsqueda, al combinar los elementos materiales que la integran y la posibilidad de ofrecer una experiencia singular y corpórea al espectador.

Sin embargo, es preciso indicar que mientras la obra de arte total buscaba cautivar al espectador para aumentar el grado de ilusión, propiciando el reencuentro con una unidad perdida - la participación en el rito -, la instalación no busca "habitar al espectador sino ser habitada por él" (Alberganti, 2013: 108). Por eso el núcleo central de la instalación ya no es el espacio escénico con sus actores, sino la relación del espectador con un campo de fuerza cimentado por las relaciones entre los objetos que contiene: el artista pone entonces en juego y en tensión a los objetos en el espacio arquitectónico, construyendo un todo

${ }^{19}$ Enraizada en las bases de este "arte total" se halla la idea de unificar el arte y la vida, fenómeno similar al perseguido en el contexto histórico en el que aparece la denominación de "instalación". 
coherente, e instando al público a tomar conciencia de su integración en esa situación que se crea.

Si bien el primer sentido que se asigna al término teatral lo define como relativo al teatro, una acepción más corriente lo presenta como una acción fingida y exagerada, aplicándose a cosas de la vida cotidiana hechas con afectación y propósito de llamar la atención (Aninat, 2004:32).

José Sánchez ofrece una perspectiva que resulta de interés cuando señala que

Hablamos de teatralidad cuando quién actúa o quien dispone lo hace en la certeza de estar siendo mirado (o escuchado) por otros y con la pretensión de determinar o condicionar esa mirada. (Sánchez, 2010: 12)

La cita da cuenta del lugar de la mirada como factor condicionante del comportamiento espontáneo, que da lugar a un actuar para el otro. Y, recíprocamente, la posibilidad de alterar intencionalmente la actuación o la construcción - de una propuesta artística, en este caso - , en busca de la devolución de esa mirada.

Estamos entonces más cerca de entender la teatralidad como una acción fingida y exagerada de una escena. Josu Larrañaga (2001) contribuye a la comprensión de esta idea cuando remite a la doble traducción que admite la palabra inglesa installation: como instalación - en el sentido de colocación, según la acepción corriente - y como investidura, tal como se utiliza el término investir en sentido oficial, es decir como una forma de conferir dignidad o importancia a algo o alguien en un momento particular. De este modo, la instalación instituye una totalidad significativa, al conferir al espacio/tiempo que ocupa, y a las imágenes y objetos que exhibe, una cualidad preeminente y diferenciada. (Larrañaga, 2001: 31)

La investidura añade un suplemento a lo existente, y es este suplemento o exceso de sentido, que lo asocia a lo artificioso, lo que determina su carácter teatral. El exceso, la intención de atraer la mirada del otro, se encarna para Sánchez en la presencia de un cuerpo que construye el artificio:

Paradójicamente, no es lo artificioso lo que destaca como excesivo, sino la corporalidad que subyace al artificio, es decir, el resto de organicidad (carne, movimiento, memoria) que ha quedado prendida en el fingimiento o el engaño (Sánchez, 2010:12) 
Para el autor tanto las motivaciones como los modos en que ese exceso se llega a manifestar pueden ser muy diversos, delimitando dos extremos: en uno de ellos, el trauma y las formas de lo trágico; en el otro, el placer y las formas de lo festivo. $Y$ entre ambos, una compleja diversidad de registros capaces de alterar la realidad a través de la ilusión, o mediante la alteración de situaciones y comportamientos (Sánchez, 2010: 12).

Este espectador que entra en la sala se enfrenta a un entorno completamente inesperado, en el que se percibe a sí mismo como un elemento del conjunto (Kabakov, 1995: 26). Por eso la instalación hace posible la experiencia estética del espacio en vivo, y la obra deviene algo que acontece durante la reunión entre el visitante y el lugar, recuperando aspectos propios del convivio. La fusión entre espacio plástico y espacio escénico permite a la obra relocalizarse en una frontera entre el arte y la vida, mediante un desplazamiento del espacio simbólico en el espacio real.

En este sentido, Larrañaga señala que las instalaciones funcionan como escenografías descentradas, dado que no sólo construyen arquitecturas efímeras puestas al servicio de una actuación temporal, sino que en ellas el punto de vista se desplaza al interior de la obra y se multiplica, en relación al recorrido aleatorio elegido por cada espectador. Como expresa el autor:

(...) el modo de proceder de la instalación tiene que ver con la particular manera de engendrar y crear espacios, a partir de la puesta en escena, tanto del mundo de los juegos como de los sueños, porque al igual que en estos dos mundos, se construye un espacio basado en una puesta en escena (...) que se activa y se modifica con el propio actuar (Larrañaga, 2001: 60)

Es por ello que la instalación, como una puesta en escena, actúa en sentido contrario al sistema de exposición propio del arte, en el cual un cuadro sobre el muro o escultura sobre su pedestal, generan una ruptura entre el espacio expositivo, la obra y el sujeto espectador. La conversión del espacio de la exposición en escena se hace posible por las particularidades de estas obras, que giran en torno a las estrategias de uso, proceso e interacción. Por eso la relación de complicidad que se establece entre el desplazamiento del espectador y la 
construcción de contenido a través de su experiencia, son consustanciales a la práctica de la instalación (Larrañaga, 2001: 36)

Este planteo de la instalación en relación a lo teatral no se vincula, ciertamente, con la pantalla o "ventana" renacentista propia del espacio a la italiana, diseñada para un espacio convencionalmente jerarquizado, sino que remite al espacio escénico como un lugar construido por la participación de un espectador como centro y eje de la propuesta, cuya misión es desde un punto de vista fijo o móvil, rearmar los fragmentos propuestos en el espacio por el artista-escenógrafo.

La instalación sería entonces una escena a la que el espectador se incorpora, donde se ha producido, se produce o puede producirse un acontecimiento" (Kabakov: 26). Pero es una escena construida deliberadamente con el propósito de impresionarlo para que internalice la ilusión, dando lugar a un entorno de inmersión total. Con la particularidad de que se trata de un espacio teatralizado que no supone un intento por transformarse en otro, ni en otra temporalidad, sino que por el contrario logra hacer sensible el espacio presente del espectador. 


\section{CAPÍTULO 4: La experiencia del arte y la construcción de un nuevo espectador}




\subsection{Un arte de la presencia: el espectador corporeizado}

Los primeros debates teóricos en torno a la instalación se inclinaron a considerar que su práctica comprendía la manipulación de artefactos, materiales y técnicas, mientras que el actor humano tendía a estar ausente. De ese modo se intentó una diferenciación respecto de la intervención en el espacio, que se pensaba - en cambio-, como un acto de performance, protagonizado por agentes humanos. No obstante, pronto se hizo evidente que la instalación no sólo presupone al espectador - como toda producción artística presupone un sujeto receptor-, sino que éste es su auténtico activador, dado que la obra se dirige a él, "como una presencia literal en el espacio" (Bishop, 2005: 10).

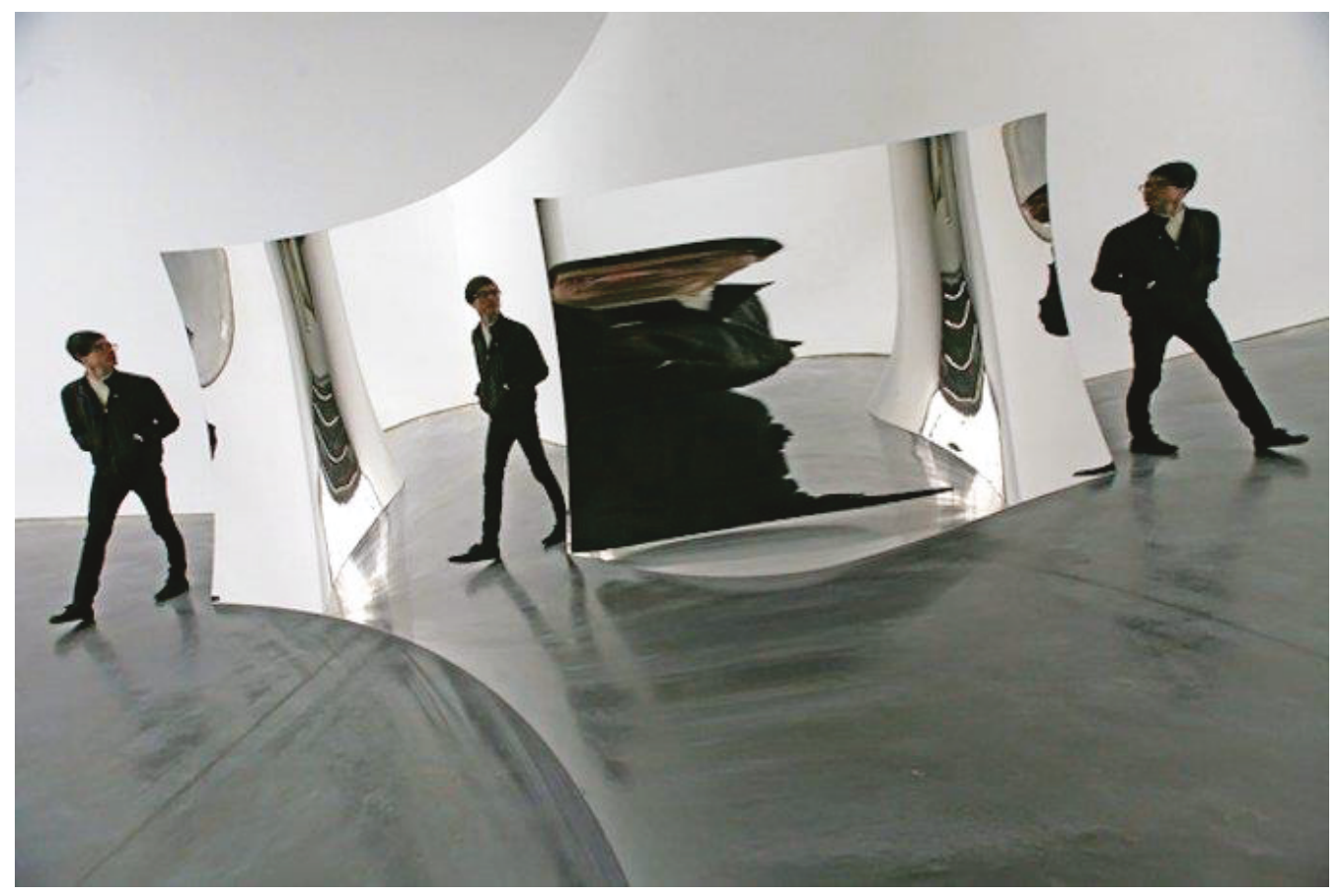

Figura 14. Vista de la instalación Vértigo, de A. Kapoor

El espectador de la instalación debe adentrarse físicamente en la obra para experimentarla, hecho que involucra múltiples referencias sensoriales y comporta, necesariamente, un compromiso corporal particular. Dado que nuestra percepción de las cosas es antropocéntrica, incluso la orientación espacial de los objetos establece referencias corporales que inciden en la recepción y experimentación de la obra. Por eso el cuerpo del espectador constituye el centro 
de gravedad o punto focal en ese territorio de convergencia de cuerpos, objetos y espacio que es la instalación: si el pigmento preexiste a la obra pictórica, la instalación en cambio se inventa y actualiza en cada ocasión, puesto que su materia es el espacio mismo, que no puede manifestarse sino en la superficie del lugar creado y habitado por un espectador.

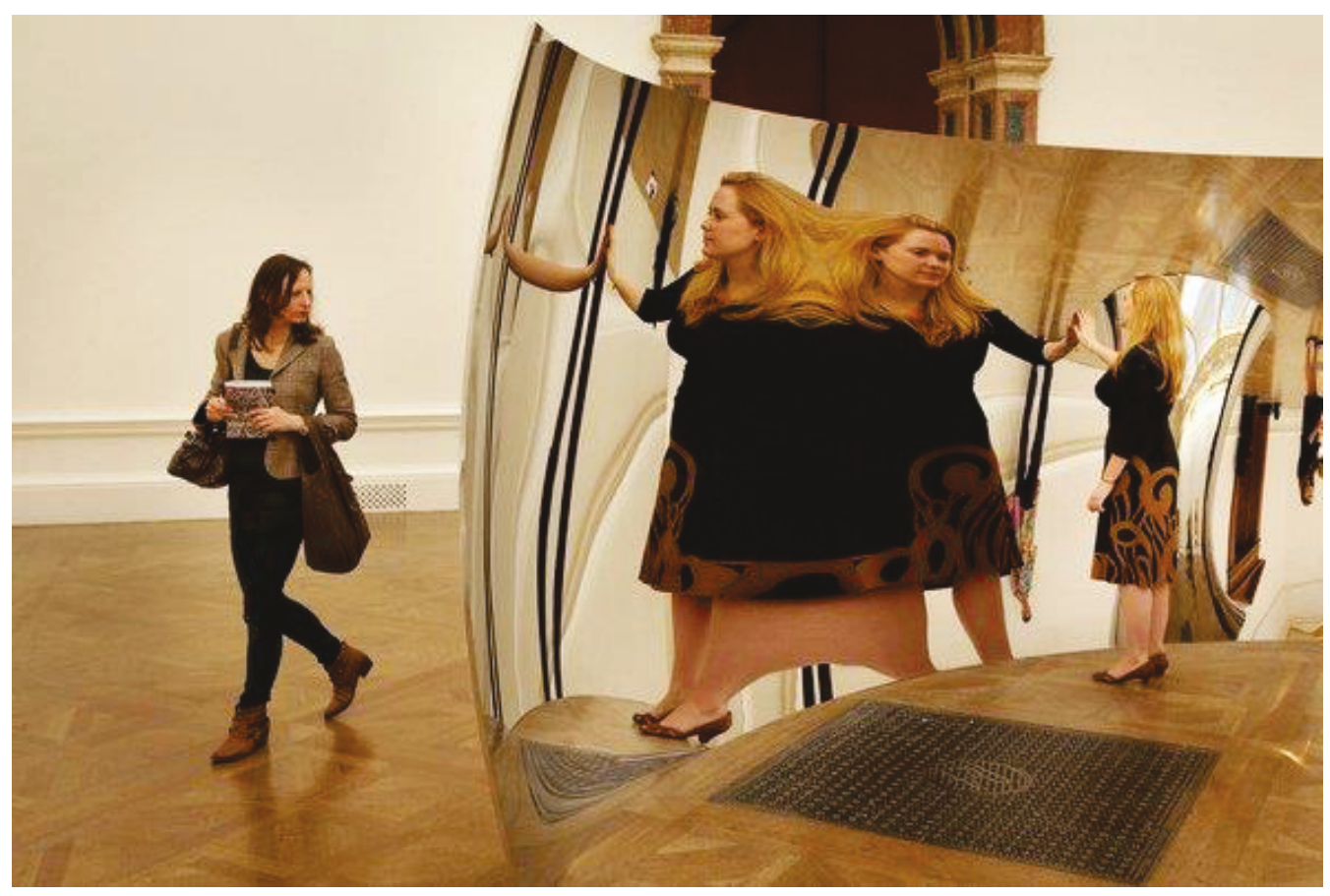

Figura 15. Vista de la instalación Vértigo, de A. Kapoor

De allí lo indispensable de la presencia, del estar ahí, que hacen de ese despliegue particular de elementos convergentes un entorno, una escena para ser habitada.

Este abordaje del espacio de la instalación como una situación única, que el espectador completará con su experiencia personal e intransferible, determina que dicha experiencia perceptiva sea, en sí misma, un problema determinante de la obra. Por eso cobra fundamental importancia la tarea de problematizar las particularidades del nuevo rol del espectador en estas producciones.

La instalación no es, entonces, un objeto único y materializado de contemplación estética sino un ensamble de relaciones entre objetos y espectadores, que dan origen a un lugar para la experimentación espacial. Esta perspectiva introduce una delimitación necesaria: deja de lado un buen número de obras que habitualmente 
son presentadas en el mundo del arte bajo el nombre de instalación, pero que carecen de un vínculo activo con el lugar de exposición, motivo por el cual se encuentran más cercanas al campo de la escultura, en sentido clásico. Trascendiendo lo objetual, la instalación se presenta como un dispositivo artístico que induce una experiencia espacial para el espectador a través de la puesta en relación de objetos provenientes de campos muy variados. Por lo tanto es también una puesta en situación y una puesta a disposición de elementos, objetos y condiciones, que estructuran la obra, y que en su conjunto acceden al estatuto de lo artístico.

Por eso el público de la instalación a menudo ha sido definido como usuario, un término que remite al vocabulario técnico propio de las instalaciones industriales -, por considerarse que constituye una alteración radical para el público del arte, tanto por su forma de relacionarse con la obra como por su inclusión en el proceso artístico. Larrañaga (2001) sostiene al respecto que las instalaciones presentan y exponen los objetos para ser experimentados, por lo que el espectador no sólo puede adentrarse en las obras y recorrerlas, sino que descubre la capacidad de incorporarse al propio proceso de construcción representativa, al integrarse en un espacio habitable, en el que no sólo los objetos cotidianos sino también su propio cuerpo son reconfigurados como obra.

\subsubsection{Acción y participación: "La habitación del borramiento", de Yayoi Kusama.}

Yves Michaud (2007) sostiene que en el marco contemporáneo de la estetización difusa, el creador es cada vez más productor de experiencias, ilusionista, mago o ingeniero de efectos. Un caso de interés en este sentido es Obsesión Infinita, la retrospectiva de Yayoi Kusama que se vio en el MALBA de la ciudad de Buenos Aires entre junio y septiembre de 2013, en particular la instalación titulada The obliteration room. La habitación del borramiento es una obra participativa que se presentó bajo la forma de un ambiente cotidiano (Figura 16.a), íntegramente blanco, tanto en su dimensión constructiva como en su mobiliario, utensilios domésticos y ornamentos. Durante el transcurso de la exposición el público fue invitado a pegar lunares adhesivos de colores intensos, provistos por el Museo 
junto con la entrada; el resultado fue un estallido de color, en el que las formas se desdibujaron y se relativizaron los ejes espaciales (Figura 16.b)

El artista instalador, como vemos en este ejemplo, propone una organización del espacio que orienta la experiencia. Coloca al espectador en ese espacio singular, y en unas circunstancias particulares, estableciendo de este modo un sistema de coordenadas que predisponen al sujeto que se adentra a tomar una actitud determinada. Así construye las condiciones de posibilidad de una experiencia, tejiendo un conjunto de relaciones espaciales entre el objeto y el espacio arquitectónico, que posibilitan al espectador tomar conciencia de su integración en una situación creada y presentada como arte.

El punto de encuentro entre la artista y el público se materializa en este caso en los lunares que son una constante en la obra de Kusama desde hace más de medio siglo. ${ }^{20} \mathrm{El}$ público acepta el juego, y la intervención resulta tan masiva que se dificulta encontrar espacios blancos donde pegar los stickers. Muchos se los apropian como souvenir de la muestra e intervienen con ellos sus pertenencias e incluso su propio cuerpo. Asimismo es posible rastrear más tarde en el espacio público en las proximidades del Museo, vestigios de los lunares de Kusama que extienden su presencia mucho más allá del medio institucional en que se presentan.

El curador Philippe Larrat Smith señala en el catálogo de la muestra que la artista tuvo la capacidad de crear un lenguaje simbólico que le permitió a la gente acceder a su mundo y a sus propias percepciones.

\footnotetext{
${ }^{20}$ Para Kusama, el lunar es el símbolo de la energía del mundo y de la vida, y lo concibe como un camino al infinito. Por eso señala que "cuando borramos la naturaleza y nuestros cuerpos, nos integramos a la unidad de nuestro entorno"
} 

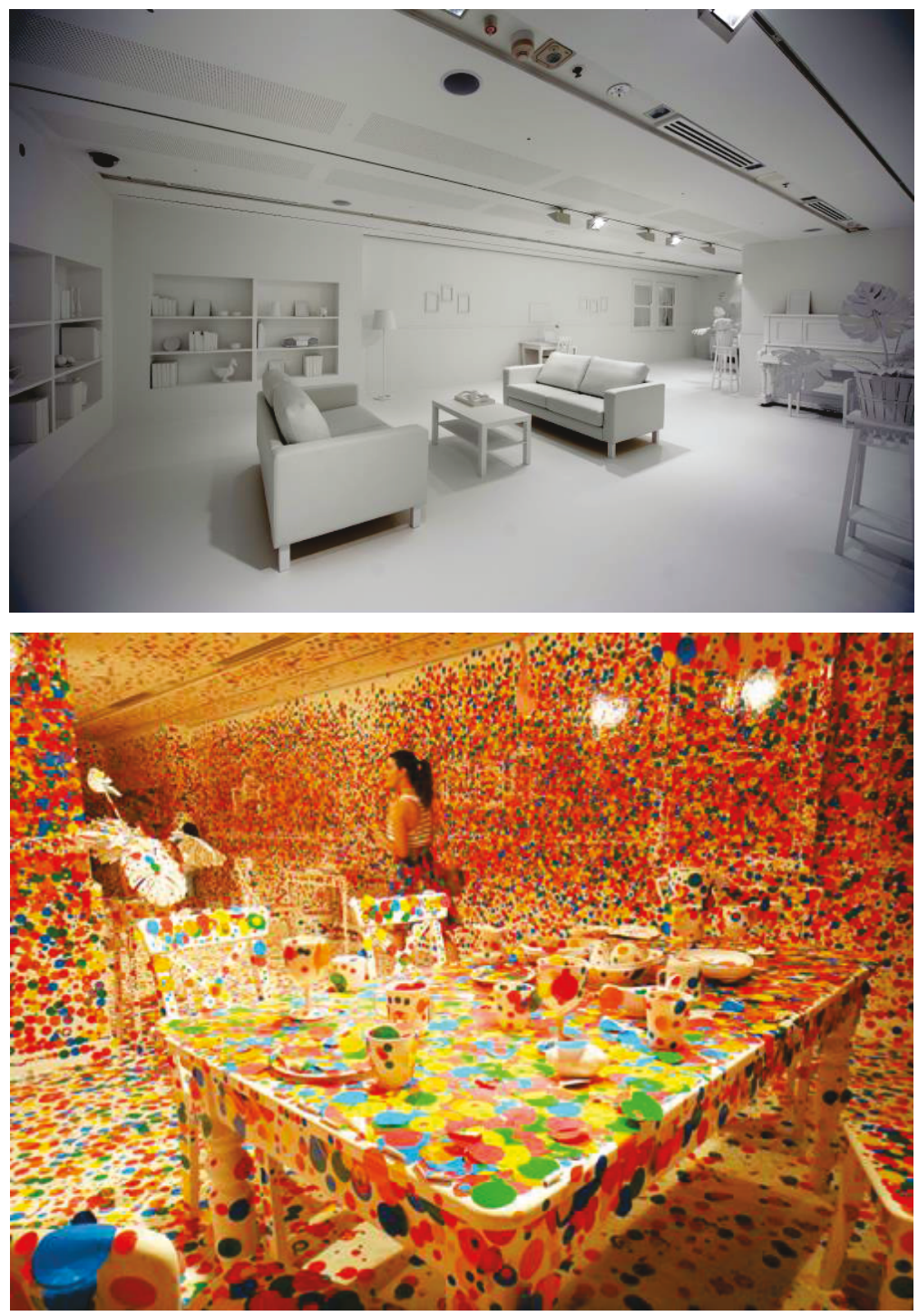

Figura 16 a y b - La Habitación del borramiento, de Yayoi Kusama.

Así, la propia obra crea las condiciones de un espacio inmersivo y envolvente, que cambia radicalmente su relación con el espectador: éste ya no se sitúa frente a una obra colocada en un espacio neutro y pasivo, sino que se descubre dentro de un espacio activo, rodeado de objetos que interactúan entre sí, y con él mismo. La frontera entre el lugar de exposición y la obra se borra, y el espectador se aparta de su rol de observador distanciado, para sumergirse en una situación lúdica y habitar un espacio. (Alberganti, 2013: 123) 

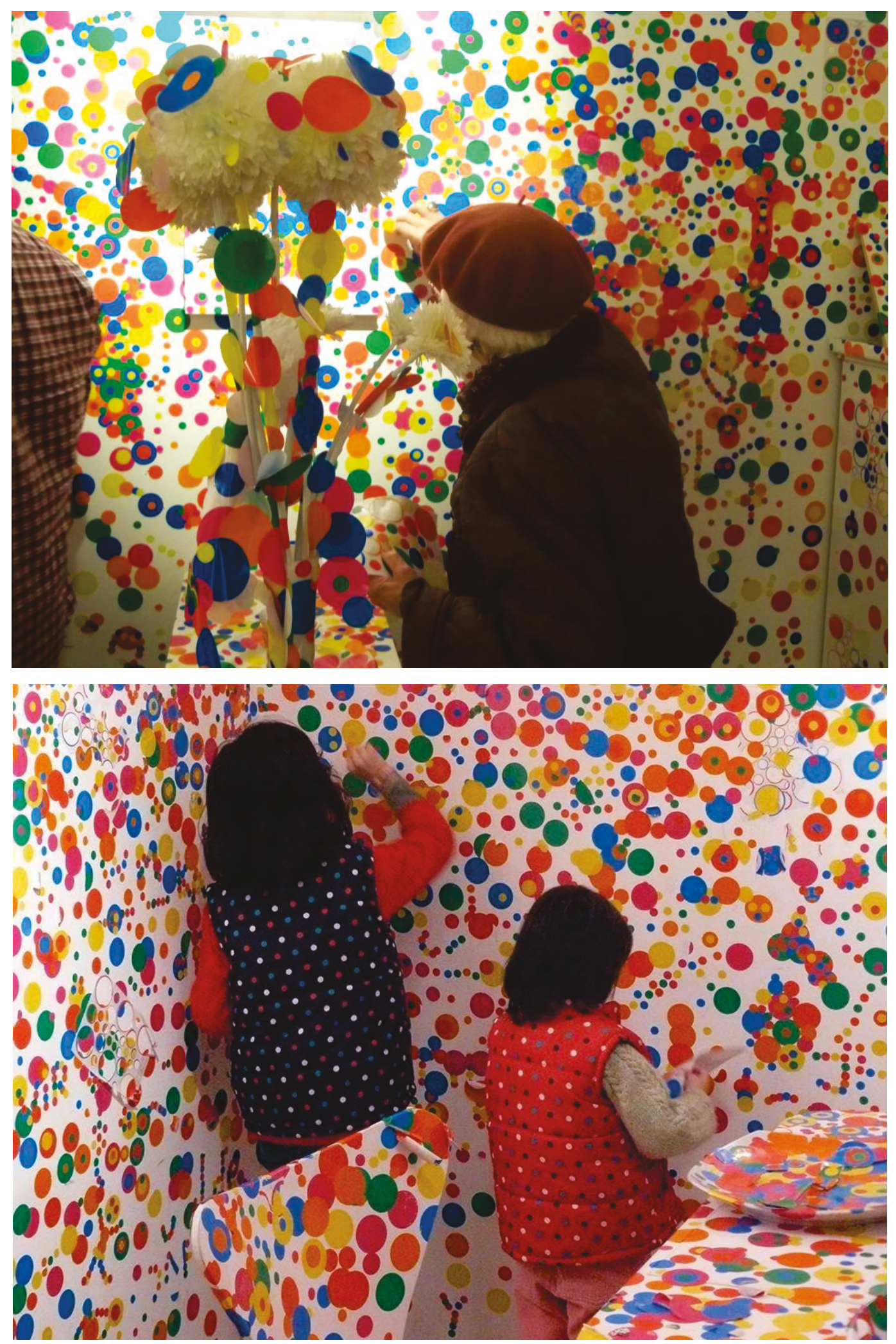

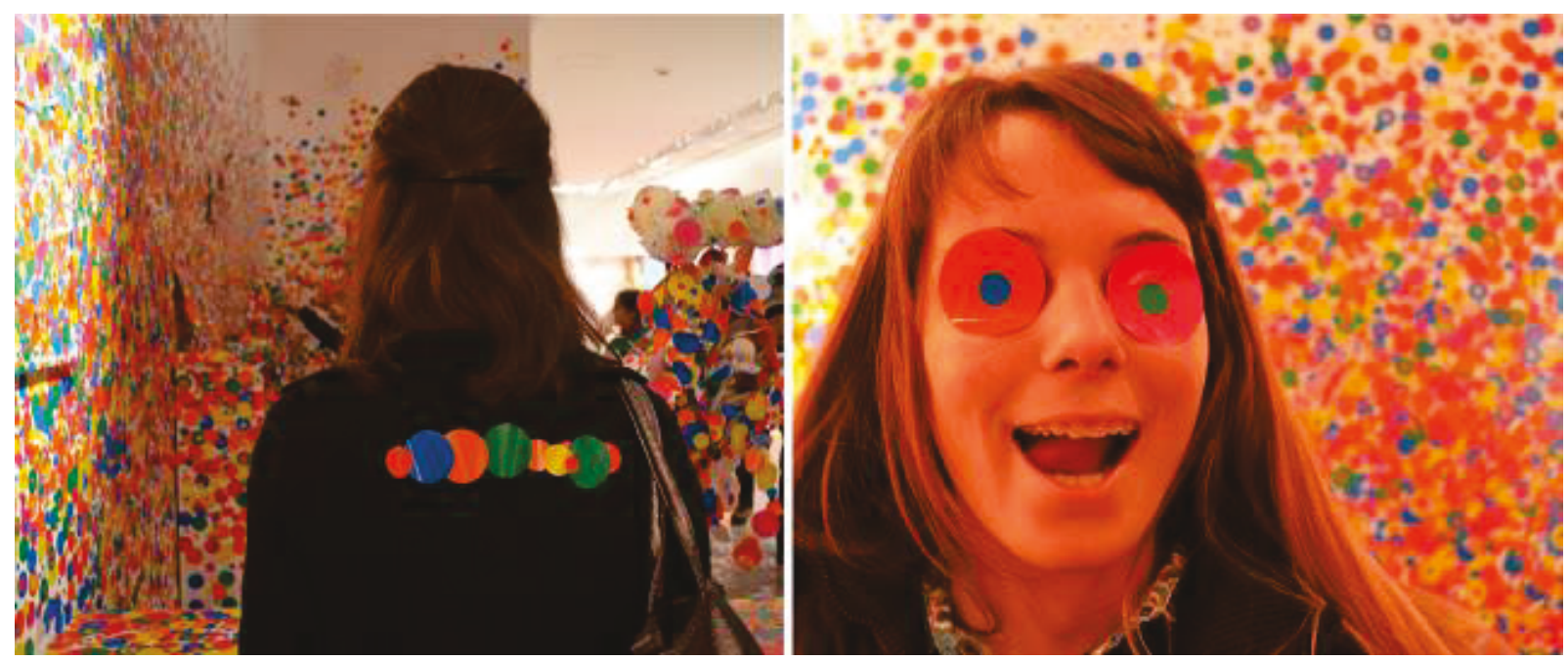

Figuras 17, 18 y 19. La habitación del borramiento (2013) de Yayoi Kusama. Vistas parciales con público participante

Inmaculada Rodríguez Cunnil (1999) considera que lo atípico de esta experiencia determina la creación de un nuevo paradigma, cuya complejidad no permite reducir a las instalaciones a un análisis tradicional - que se agote en unos cuantos significados propuestos -, sino que será preciso abordarlas teniendo en cuenta su puesta en escena, y la presencia del cuerpo del espectador - visitante que la transita. Al respecto, Nicolás de Oliveira y Nicolás Petry señalan que:

Desde finales de los sesenta, la introducción en la creación y la reflexión del arte conceptual (...) permitió el desarrollo de una comprensión de que la posición del espectador con respecto a una obra de arte no está fijada en un punto de vista, sino que está continuamente transformándose como resultado del proceso y de los impulsos conflictuales de la experiencia social (Oliveira et al, 1994: 28)

\subsection{Una aproximación a la mirada fenomenológica.}

De este modo, la instalación ahonda en la dimensión pragmática que toda obra posee, pero que en ella se hace más evidente por la inclusión del espectador y su relación con el entorno, determinada en buena parte por la misma escala humana. La escala incide en el vínculo entre el propio cuerpo y los objetos, implicando al mismo tiempo al espacio que los separa. Por lo tanto en la lectura de la obra que lo 
incluye, el espectador no sólo pone en funcionamiento una mediación visual sino enteramente corporal.

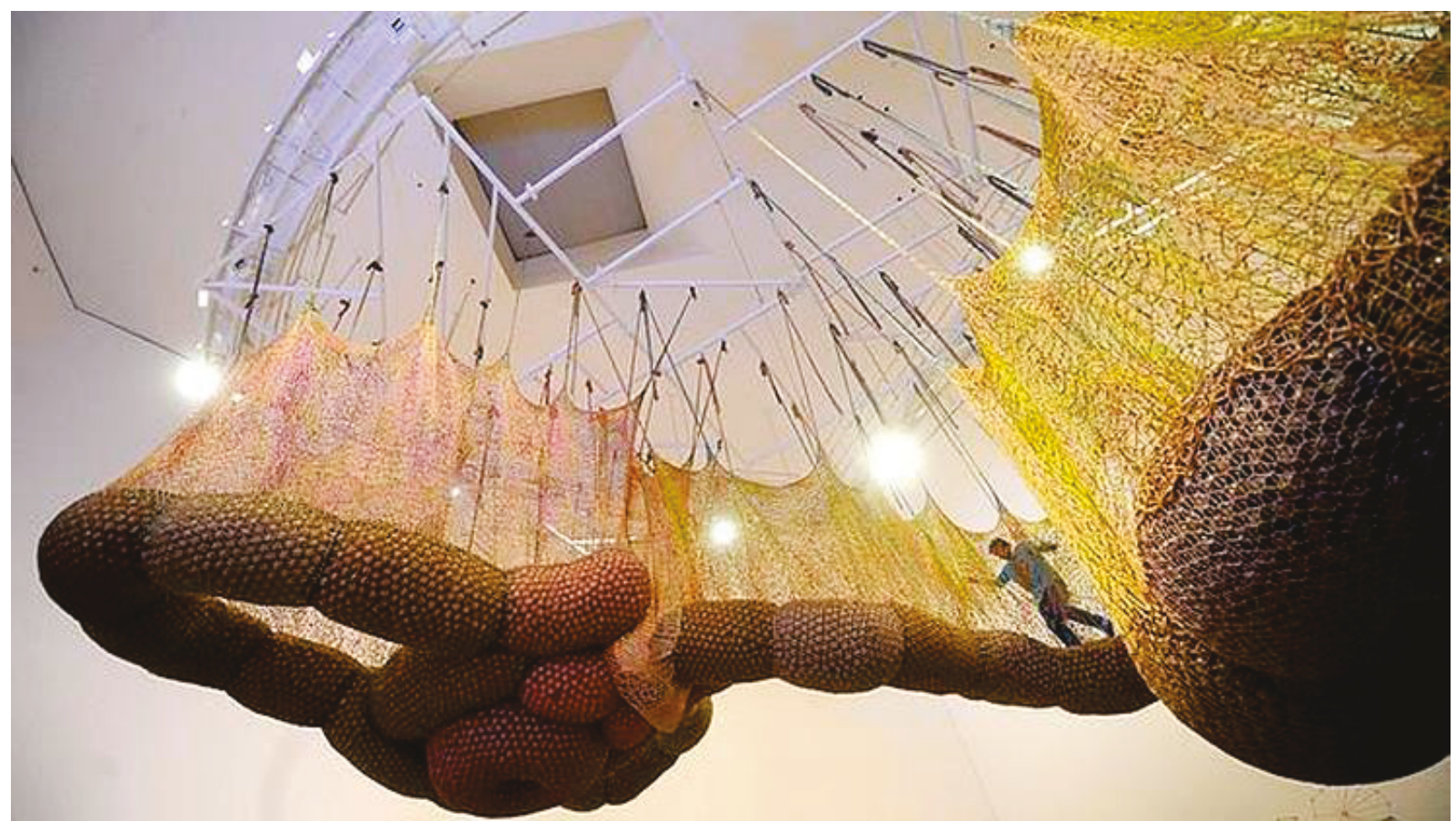

Figura 20: Vista de la instalación La vida es un cuerpo del que formamos parte (2012), de Ernesto Neto. Guggenheim, Bilbao, 2014

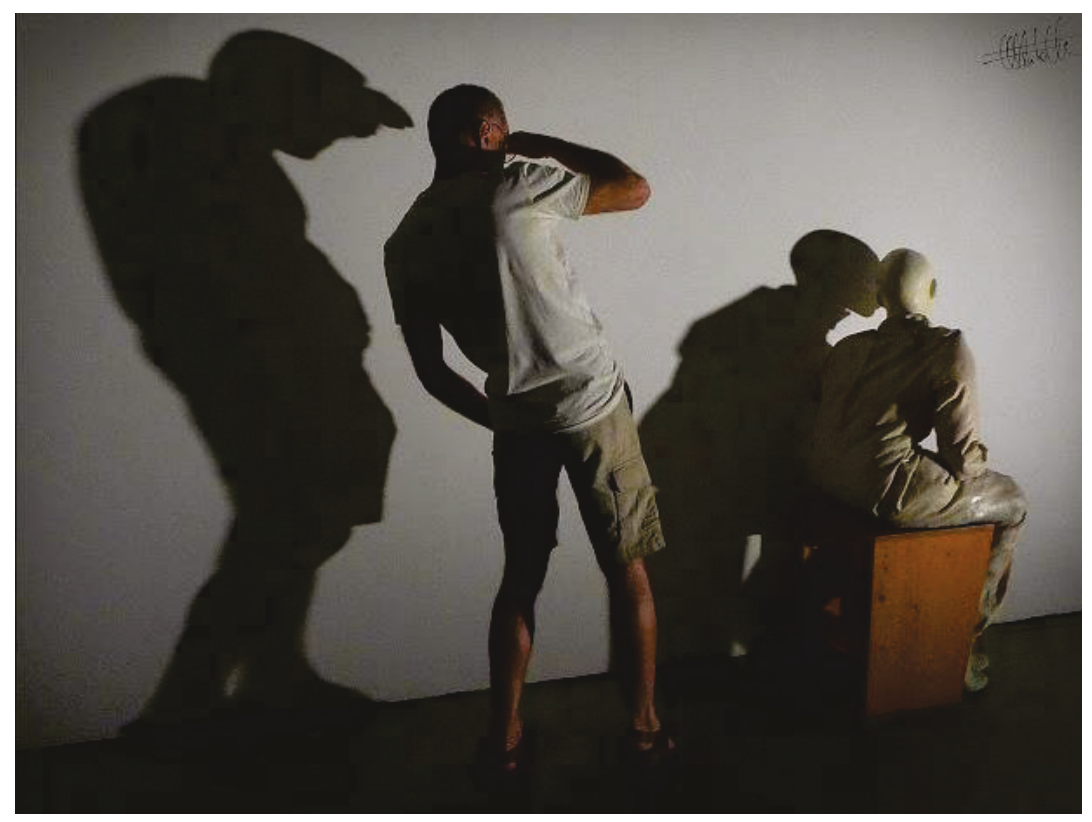

Figura 21: Retrospectiva de Juan Muñoz. MNCARS, Madrid, 2009 
La conciencia en el uso de la escala también reviste, por lo tanto, cierta cualidad performativa, dado que promueve la integración total del cuerpo del espectador en la obra misma. En relación a la ocupación del espacio que propiciara el Minimalismo ( $y$ que desde nuestro punto de vista heredara luego la instalación), Marchán Fiz plantea que

tomaba como motivo estético la sospecha fenomenológica, tamizada ahora como idea estética, de que la percepción del objeto y la percepción del espacio, su ser cosa y la espacialidad por ella incoada, no constituyen dos problemas distintos y, menos, excluyentes (Marchán Fiz, 1994: 36-37)

Se evidencia aquí un interés por la fenomenología, que no resulta extraño teniendo en cuenta el impacto que había tenido por entonces la obra de Merleau-Ponty Fenomenología de la percepción, publicada en 1945. Los objetos minimalistas se reducían a formas simples. Pero el interés por las condiciones de recepción de la obra superaba con creces el evidenciado por la apariencia de la misma. Esta actitud es calificada por Marchán Fiz como fenomenológica, ya que considera que

(...) parece tematizar en su arte algunas de las aventuras de un zambullirse en los fenómenos de ese aparecer del ser en la existencia en el ámbito de la percepción. En este sentido, el artista minimalista eleva a material artístico unas estructuras de comportamiento, anteriores a la aparición de la imagen y los objetos reconocibles, cuyos correlatos objetivos son los cuerpos geométricos elementales. Pero aun así, es capaz de sumergirse a través de la experiencia perceptiva en las espesuras del mundo pues todo lo demás vendrá por añadidura (Marchán Fiz, 1994: 32-33)

Partiendo de principios husserlianos, Merleau-Ponty indaga en una serie de cuestiones que no son ajenas a la interpretación que se puede hacer de las instalaciones. Su objetivo es apartarse de la estructura del cogito cartesiano en lo que respecta a la percepción, a la que considera más bien como una experiencia encarnada. De este modo deja de lado el carácter vacío y abstracto del primero, para privilegiar la unidad del cuerpo con un mundo determinado.

Desde esta perspectiva, es lógico pensar que la recepción de una instalación obras que Merleau-Ponty no llegó a conocer como tales, pues el término se acuñó posteriormente a su muerte, ocurrida en 1961 - responda más a una articulación del cuerpo en el espacio que a una mera percepción distanciada. Para Inmaculada 
Rodríguez Cunnil (1999: 506), la encarnación propiciada por Merleau-Ponty resulta ser un precedente de interés para entender que el cuerpo del espectador no se encuentra en un espacio, sino que él mismo lo configura. Asimismo, entiende el sujeto que percibe como una entidad que está siempre en proceso de renovación. De allí que el carácter performativo o espectacular, el recorrido inherente al desplazamiento del cuerpo del espectador por un espacio, se manifieste también acorde con esta fenomenología de la percepción planteada por Merleau-Ponty.

Otras cuestiones fenomenológicas podrán ser también de importancia: el concepto de cuerpo como ser tocante y tocado aporta cierta consistencia paradójica que es afín a la paradoja de la instalación, puesto que la instalación es una propuesta artística que se visita, se penetra, cuya característica definitoria es precisamente su falta de definición explícita en contraposición a sus técnicas múltiples.

En ella la distinción entre objeto artístico y sujeto espectador es mínima, y la interacción completa, aspectos ya presentes en las primeras instalaciones minimalistas. Y no se trata ya sólo de que la obra rapte un espacio a su alrededor (como propone Javier Maderuelo), sino que este espacio raptado se confronta paralelamente con el desarrollo que realiza el hombre como ser espacial.

Esta es, a nuestro entender, la vertiente fenomenológica presente en la instalación. Por otra parte, el espacio es, además una concepción humana, una coordenada, relacionado con la actitud vital. Por eso no podremos hablar en el caso de las instalaciones de un espacio matemático u homogéneo, sino de un espacio vivencial. Pero este espacio vivido ha de poder ser categorizado como diferente del resto de las experiencias cotidianas, a efectos de que logre adquirir su forma, su peso, frente a la corriente general de vivencias, configurando una experiencia estética.

Así el cuerpo del espectador se configura en la instalación como variable y como referencia, determinando las nociones de adelante y atrás, izquierda y derecha, arriba y abajo, entre muchas otras; mientras que su desplazamiento posibilita la captación del sentido de la tercera dimensión. 


\subsection{Coordenadas móviles: tiempo/ espacio/ espectador en la obra transitable.}

El desplazamiento se constituye en un hecho inherente a las relaciones internas de la obra. Por eso la experiencia espacial del visitante es antes que nada una experiencia perceptiva que pone en juego los sentidos y el movimiento, siendo imposible pensar esa implicación del cuerpo en movimiento en forma independiente de la propia percepción. El tránsito de los cuerpos determina una superposición de dos espacios, hasta entonces diferenciados: el espacio físico donde la propuesta se sitúa y el espacio de representación. Al respecto, Simón Marchán Fiz señala:

En cualquier caso implica un espacio que envuelve al hombre y a través del cual éste puede trasladarse y desenvolverse. Tal vez, la nota fundamental es la extensión y la expansión transitable de la obra en el espacio real. No se trata de una reproducción, sino de la instauración de una realidad en una situación espacial (Marchán Fiz, 1990).

Podemos afirmar, por tanto, que el espacio vivencial se convierte en espacio artístico. Y el vínculo entre ambos supone la presencia de un cuerpo que lo transita y que opera como un elemento más de la obra. Esta presencia deberá ser tenida en cuenta por el artista, ya que en muchos casos será tarea del espectador proseguir la obra y completarla.

\subsubsection{Habitar y experimentar. Edificio, de Leandro Erlich.}

Un caso de interés en esta línea es la instalación Edificio (2012) de Leandro Erlich, exhibida actualmente en el hall central de la Usina del Arte, en la ciudad Autónoma de Buenos Aires (Figura 22).

Las instalaciones de Erlich proponen situaciones y espacios que alteran la percepción, explorando el universo de las simulaciones y los efectos ópticos y cuestionando los límites de la realidad cotidiana para conformar una realidad propia. En sus Edificios, el artista se propone desafiar a la ley de gravedad para que el público experimente la posibilidad de trepar, colgarse y hasta caer por una típica fachada de un edificio porteño. 

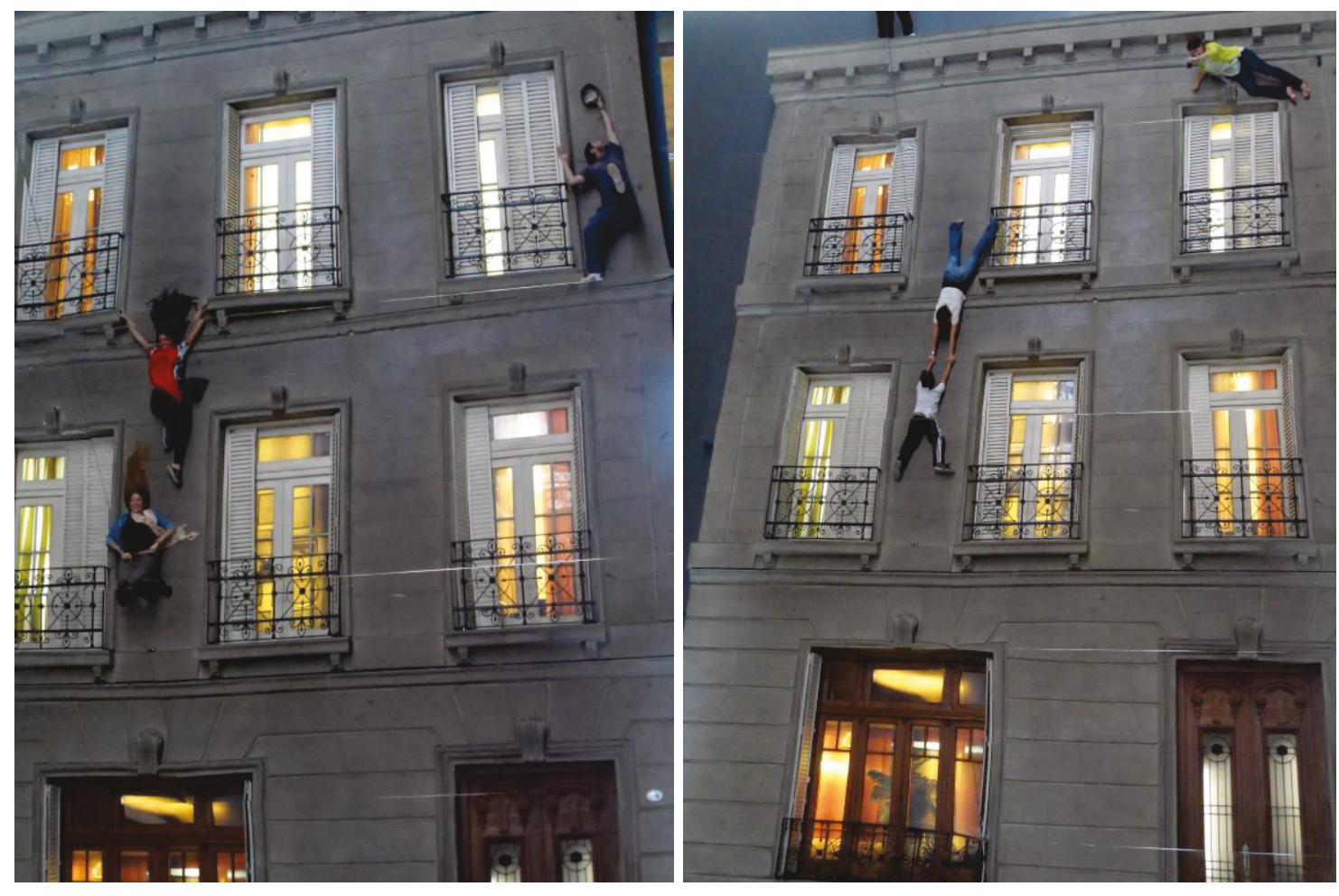

Figuras 22 y 23: vistas parciales de la instalación Edificio (2012) de Leandro Erlich. Usina del Arte. CABA.

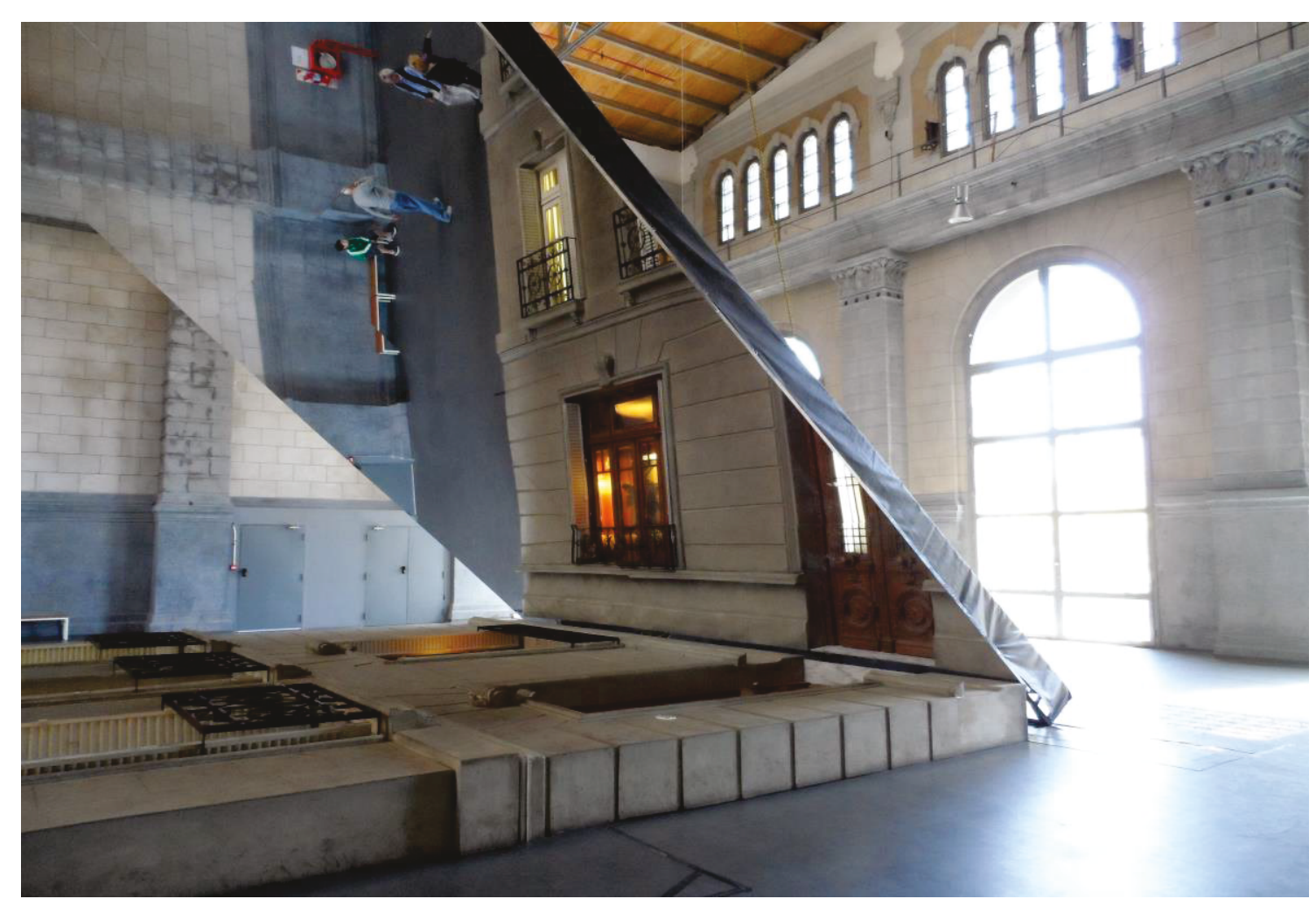

Figura 24: Edificio (2012) de Leandro Erlich. Detalle del dispositivo espacial. Usina del Arte. CABA. 


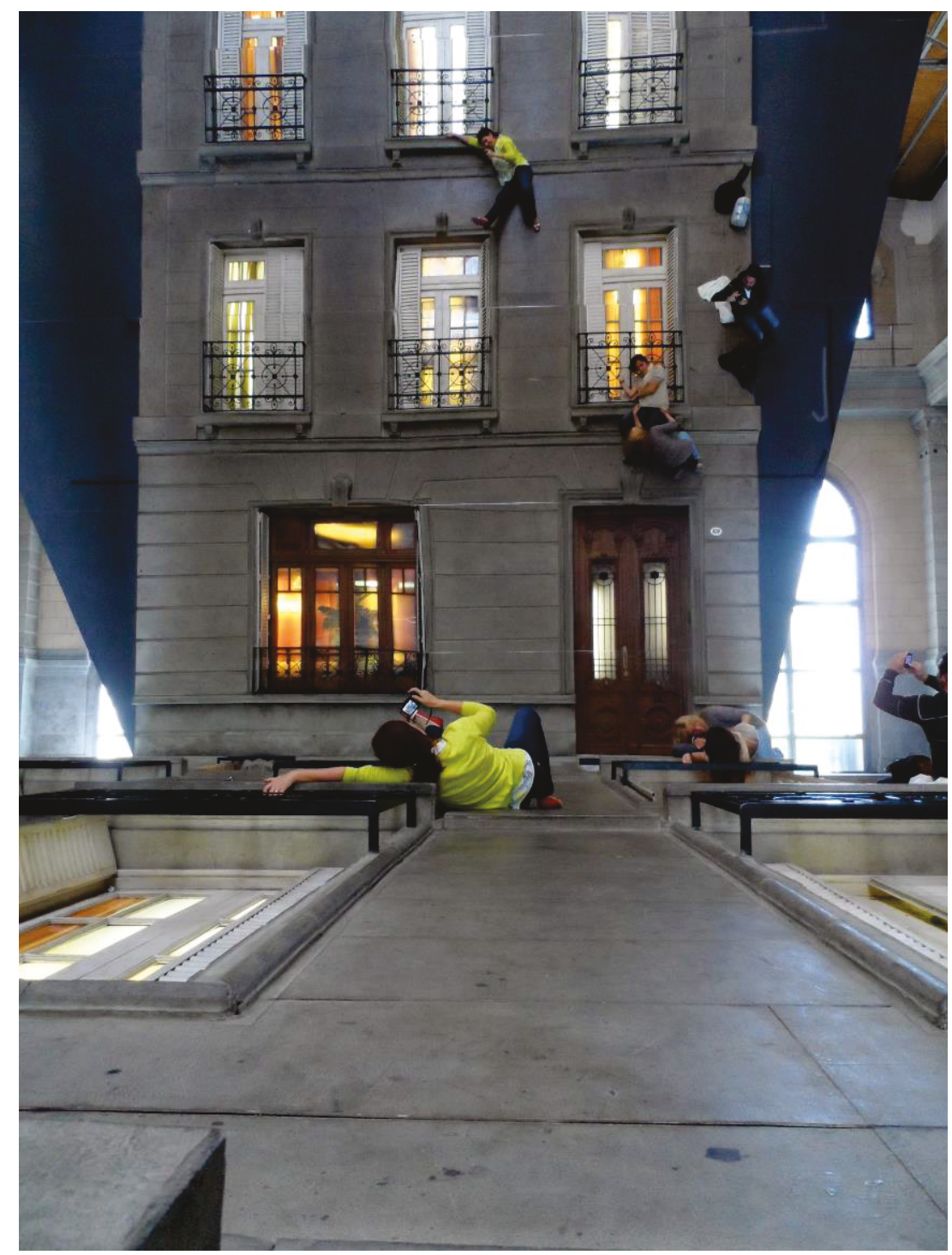

En relación a la experiencia que promueve, el dispositivo es sencillo (Figura 24). Consta de una plataforma que reproduce horizontalmente una fachada tradicional de Buenos Aires: un gran practicable de madera revestido en cemento, con aberturas, persianas y rejas originales. Y de una estructura sostenida desde el techo, formando un ángulo agudo con respecto al practicable, revestida con 12 planchas de polímero, que logra que quienes se desplazan en el suelo sobre dicho practicable puedan verse reflejados en la superficie espejada.

El planteo de la instalación se propone intensificar las sensaciones de los espectadores, para forzarlos a que "pongan el cuerpo", a que lo cedan con el objeto de poner la obra en marcha. La ilusión que se crea hace que veamos a la gente caminando por las cornisas, colgada e incluso suspendida en el aire. 
Se trata en este caso de una inmersión de características singulares, ya que opera en la mediación entre el comportamiento corporal que habita la tridimensionalidad y la imagen proyectada. Se advierte un interés particular por parte de estos espectadores -mitad voyeurs, mitad performers - de componer con su cuerpo situaciones lúdicas, observándose una marcada tendencia a registrar fotográficamente la secuencia de acciones que sus propios cuerpos componen en la pantalla, en muchos de los casos en forma de autofoto.

Las obras de Erlich conmueven poderosamente nuestro de sentido de realidad, haciendo que el espectador cuestione y relativice su propia percepción, obligándolo a asumir nuevos modos de pensar el mundo, a través de un compromiso sensorial, lúdico y participativo.

\subsubsection{De la idea del artista a la voluntad del espectador. Marulho (el murmullo del mar), de Cildo Meireles.}

A partir de su cualidad de transitable, las instalaciones pueden presentar distintas situaciones de enunciación, circulación y recepción. En algunos casos, involucran una única sala, por lo que el visitante en cuanto ingresa puede componer una idea integral de la obra, que profundizará posteriormente con su desplazamiento voluntario por circuitos más o menos pautados por el artista.

Este es el caso de Marulho (El murmullo del mar) ${ }^{21}$, del artista brasileño Cildo Meireles. La obra se presenta como un gran muelle de madera frente al mar (Figura 25), una plataforma elevada desde la que se puede contemplar un mar creado por el efecto óptico de 17.000 libros abiertos, de cubiertas azules. Cualquier observador, aun poco familiarizado con el mundo del arte, sería capaz de definirlo como un paisaje. Pero es un paisaje tridimensional, susceptible de ser transitado, vivenciado, actuado.

\footnotetext{
${ }^{21}$ La obra fue presentada por primera vez en el marco de la sexta Bienal del Mercosur, llevada a cabo en Porto Alegre (Brasil) en 2007. Esa edición tomó como idea rectora el cuento de Guimarães Rosa, titulado $A$ Terceira Margem do Rio (La tercera orilla del río). La metáfora de la tercera orilla supone la posibilidad de superar oposiciones binarias e introducir posicionamientos independientes y libres de dogmatismos para percibir la realidad. En torno a la Bienal, significó una defensa de las geografías culturales en contraposición al determinismo de las fronteras geopolíticas, y la búsqueda de un modelo intermedio entre lo regional y lo global: arraigado en el Mercosur, pero no por ello limitado a él.
} 


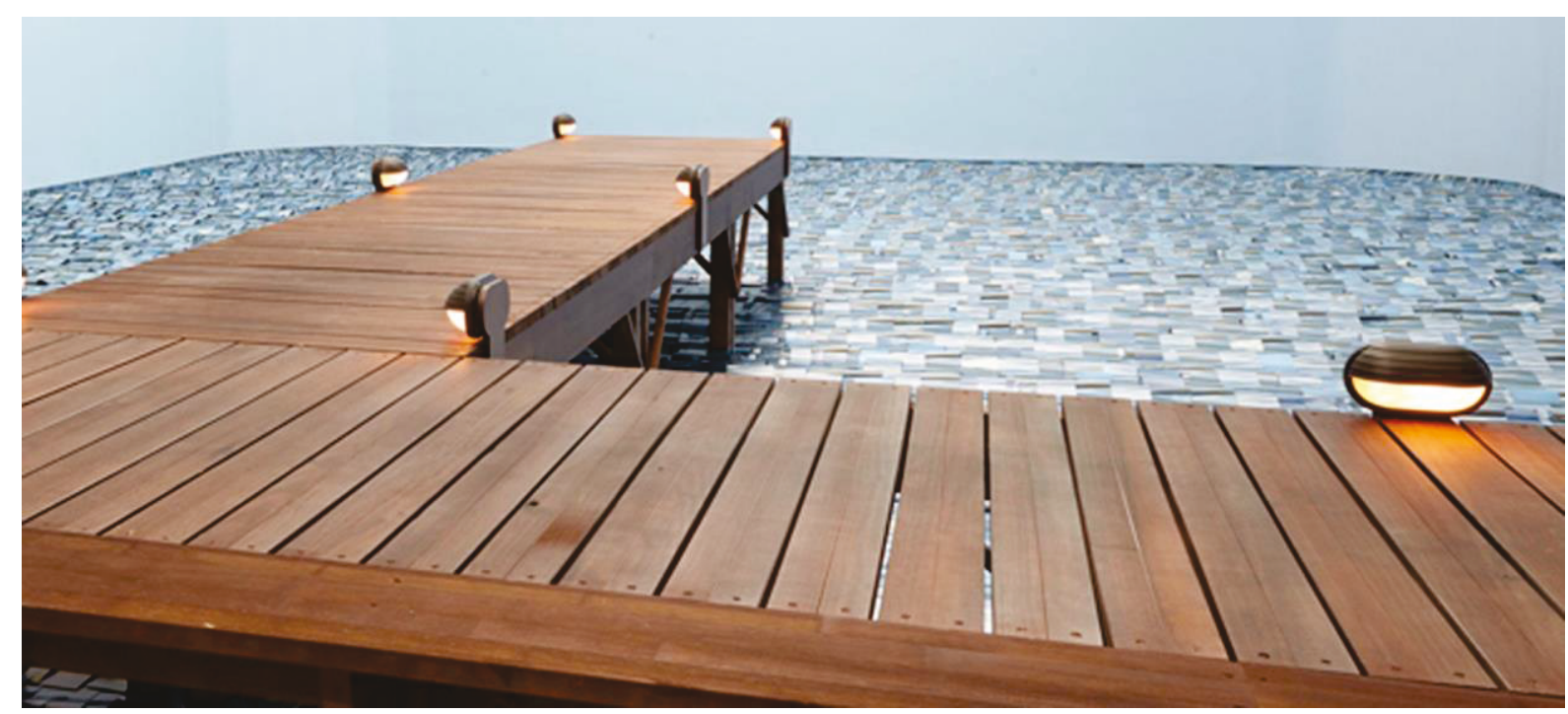

Figura 25: Vista de Marulho (El murmullo del mar) (1991-1997), de Cildo Meireles en Fundación Hangar Biccocca. Milán (2014)

El sonido cumple también un papel determinante en la obra: la palabra 'agua', pronunciada por voces de hombres y mujeres de distintas edades, en un total de ochenta lenguas, articula un rumor ininteligible que recrea el murmullo del mar.

Marulho establece nutridos vínculos con lo escenográfico, apelando a un espectador visitante que se introduce en ese paisaje y lo completa, con el préstamo circunstancial de su propio cuerpo (Oliveras: 2000, 53). Por eso nos resulta casi imposible distinguir la obra de la joven sentada en el extremo del muelle, con sus piernas suspendidas (Figura 26), o del niño que corre por allí con un globo rojo. Porque en ese marco los cuerpos logran un proceso solidario en el que el lugar adquiere referencias teatrales, al convertirse en un escenario de intercambio. De allí la dificultad del registro que caracteriza a la instalación ante la imposibilidad de reproducir la vivencia, que es necesariamente individual, fugaz e intransferible. 


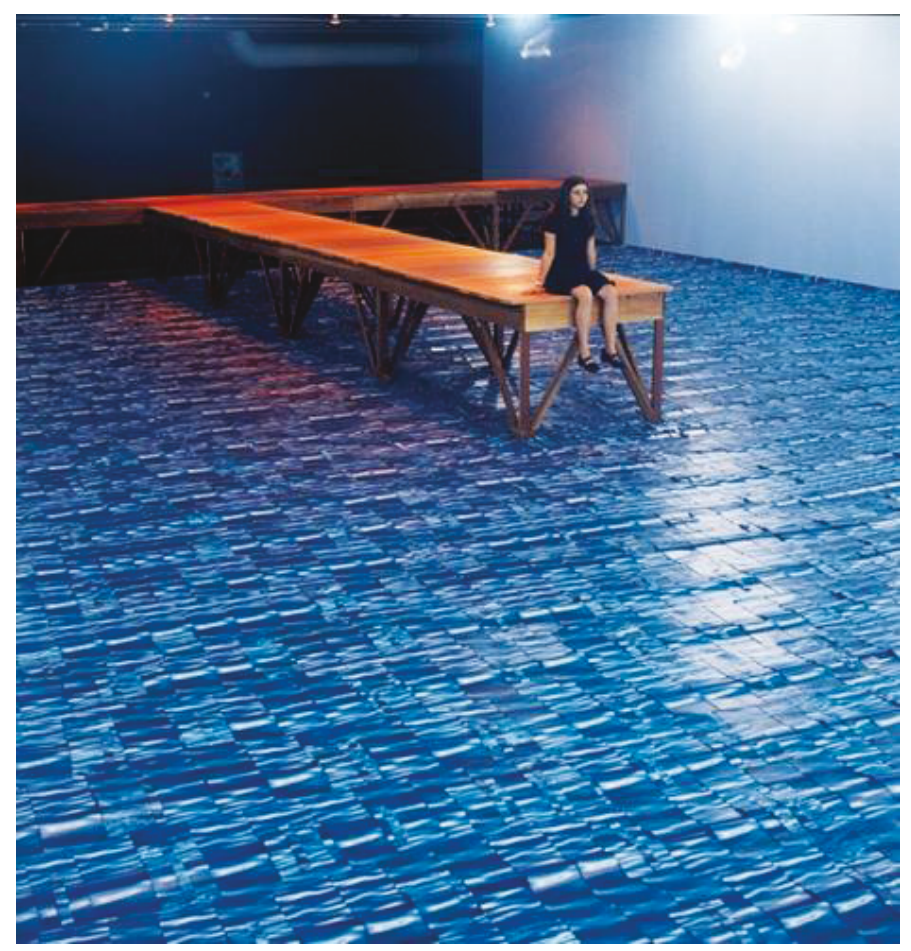

Figuras 26 y 27. Vistas de la Instalación Marulho (El murmullo del mar) 1991-1997, de Cildo Meireles con público.

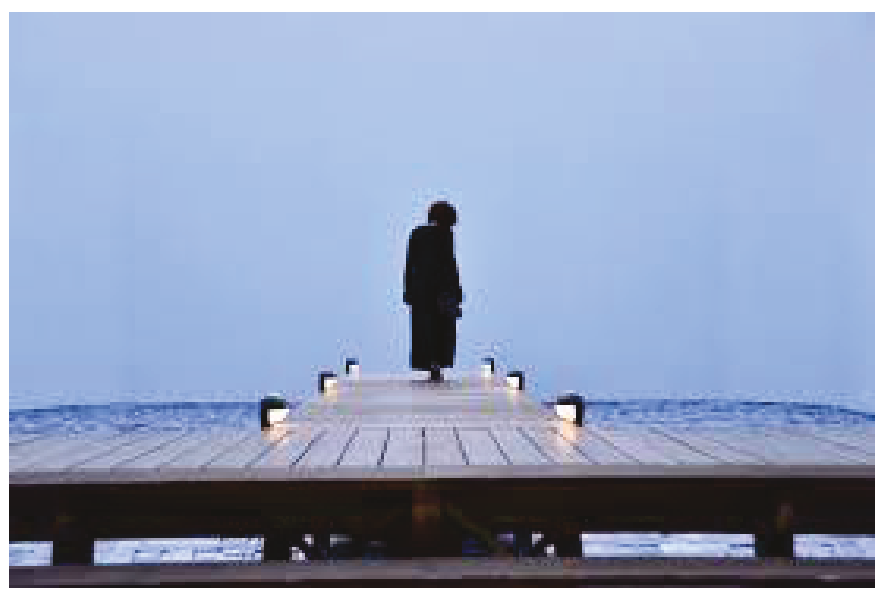

Este carácter efímero y la necesidad de tener un receptor concreto, decidiendo el recorrido de la obra y su concepto, llevaron a Elena Oliveras a hablar de la instalación como arte de la presencia. Para Oliveras, la instalación -junto al teatro, la ópera y la danza - conforman un frente de presencia, por ser artes de la proximidad, cuya identidad se fundamenta en un aquí y ahora inmediato del cuerpo del actor, bailarín o del propio espectador-visitante, (Oliveras, 2000: 37), situación que corrobora una vez más un vínculo con lo escénico. De este modo, cuando un espectador-visitante ingresa en el espacio del actor, se sumerge en 
una situación ficcional y se construye en torno a él un particular efecto de realidad, dado que toda acción, o todo gesto pueden ser leídos como constitutivos de la propia obra.

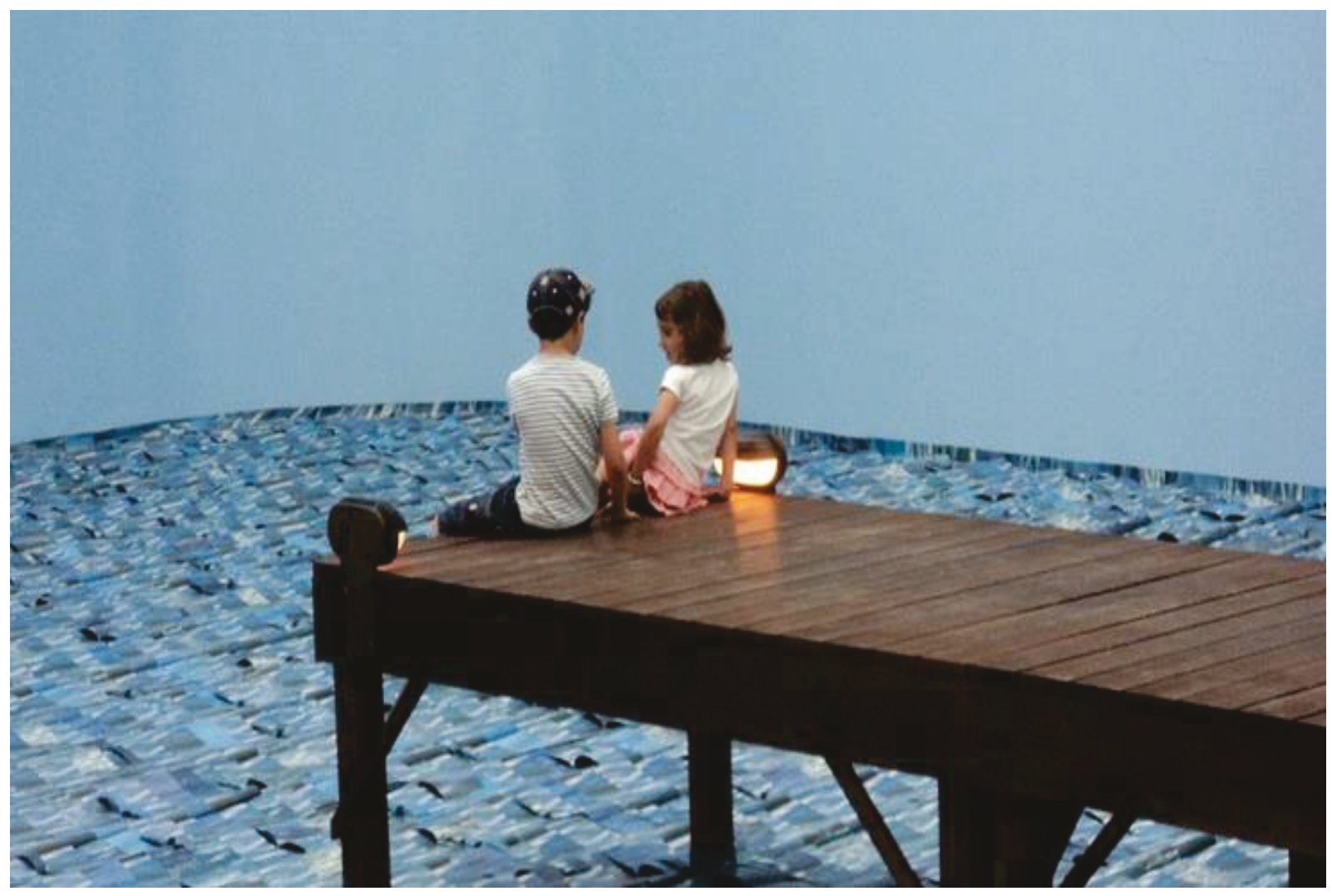

Figura 28: Vista de la Instalación Marulho (El murmullo del mar) 1991-1997, de Cildo Meireles con público.

\subsubsection{Narración oculta en tres tiempos y un espacio: Desvío al rojo, de Cildo Meireles.}

En otras obras, en cambio, la circulación por espacios múltiples - vinculados formal y temáticamente- determina una experiencia más compleja. En esos casos, el público debe asimilar nuevas impresiones por contraste con aquéllas que ha retenido de la sala anterior, lo que una vez más propicia la analogía con 
cierta narratividad próxima a la práctica teatral.. Al respecto, Ilya Kabakov señala:

El paso de un espacio de la instalación a otro ocasiona un efecto dramático particular, que permite poner en juego esta serie de encadenamientos; como en una obra de teatro, el visitante y sus impresiones son completamente diferentes al final de la instalación de lo que eran al principio. La comparación con la dramaturgia de una obra [...] es, en este caso, totalmente pertinente, aunque en el teatro, los cambios se producen sobre la escala temporal, mientras que en la instalación tienen lugar en el paso de un espacio a otro (Kabakov en Larrañaga, 2001).

Podemos dar cuenta de este tipo de lectura, que involucra de un modo particular la asociación de las dimensiones espacial y temporal en Desvío para o vermelho (Desvío hacia el rojo), de Cildo Meireles, una instalación concebida entre los años 1967 y 1980, y presentada por primera vez en 1984. La obra consta de tres espacios sucesivos:

El primero, titulado Impregnación (Figura 29), fue ideado entre los años 1967 y 68. Consiste en una habitación de unos $50 \mathrm{~m} 2$ que reconstruye un living de clase media brasileña de las décadas del 60 y 70 . Allí se concentran una infinidad de objetos domésticos (industriales y artesanales) de color rojo, una "saturación roja producida por la acumulación de todos los objetos rojos posibles" (Brito, 1995). Ninguno ha sido pintado por el artista; son el producto de una rigurosa búsqueda y selección. Muebles, electrodomésticos, adornos, libros y discos rojos conviven en un conjunto impactante. El espacio mismo aparece engendrado por el color, que prevalece sobre cualquier otra dimensión. Suely Rolnik comenta lo siguiente, con relación a su experiencia en el lugar:

El color las constituye [a las cosas] a punto tal de que parece emanar de ellas, contaminando la atmósfera del recinto y de mi propio cuerpo: mis ojos, mis oídos, mi piel, mi respiración, mi subjetividad. No por casualidad, Cildo denominó a este primer espacio Impregnación (Rolnik, 2009). 


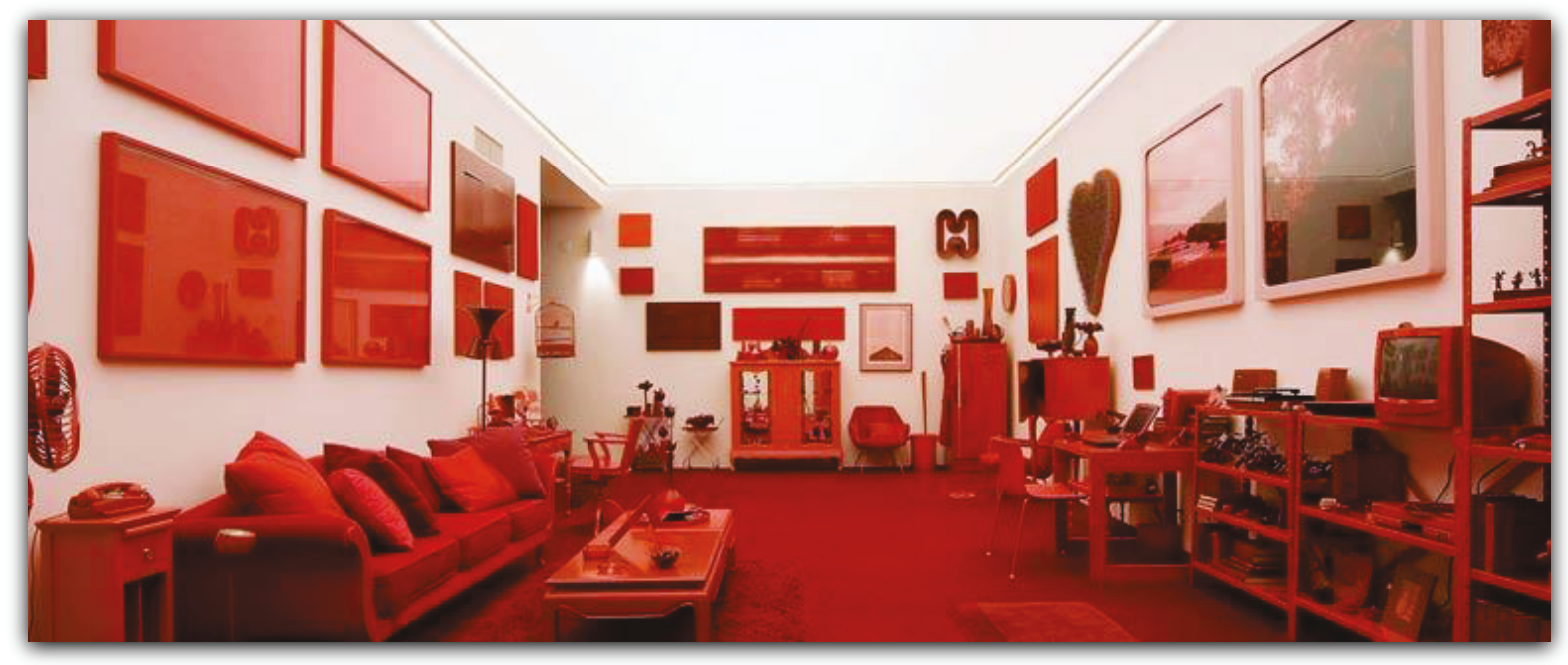

Figura 29 a y b. Desvío hacia el rojo. Impregnación (1967-1984), de Cildo Meireles

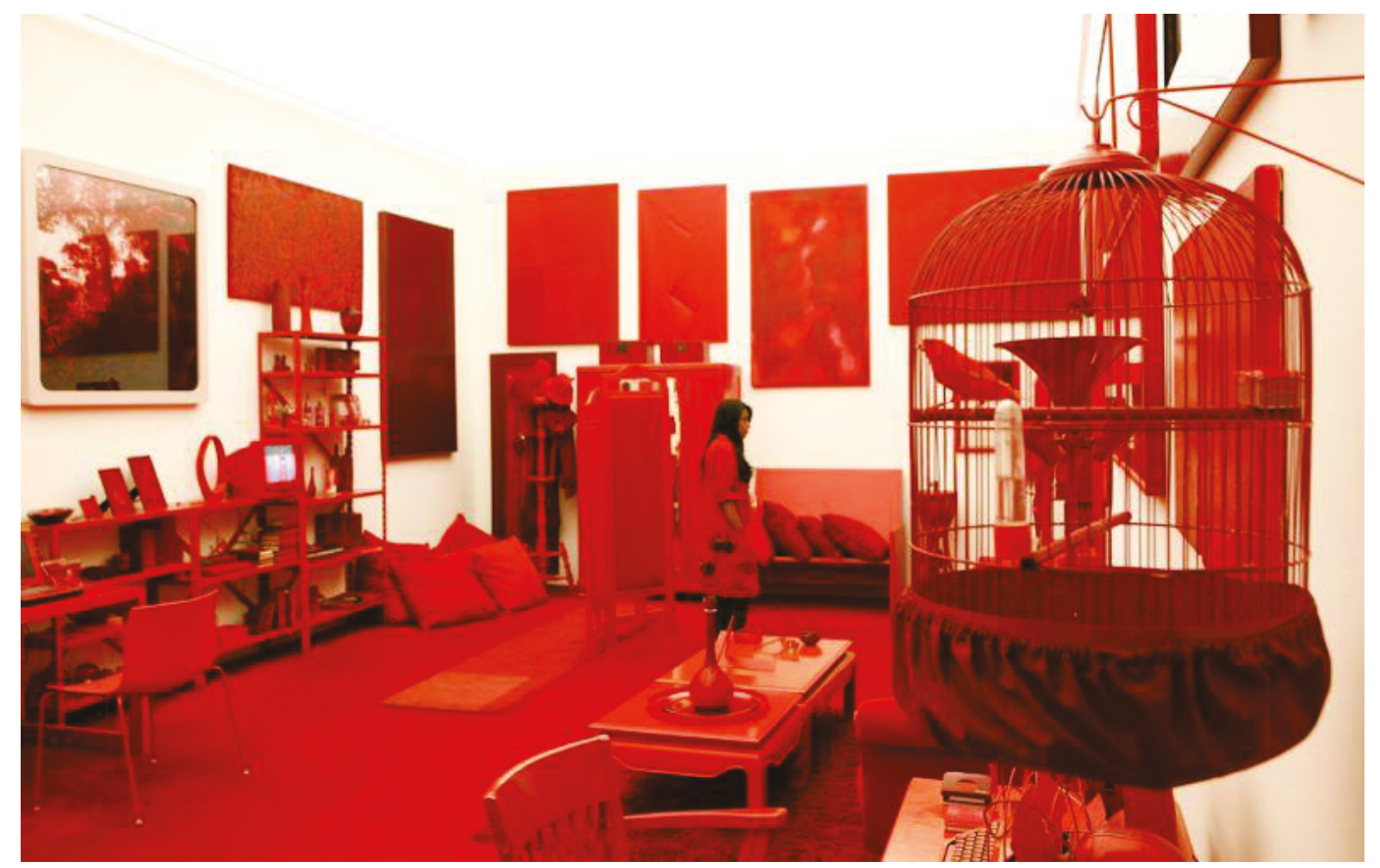

Como en la mayoría de las obras de Meireles, tampoco aquí se descuida la referencia a lo auditivo: se percibe un sonido de agua que fluye permanentemente y emana de un video que se reproduce en la propia instalación, transmitido en loop por el televisor rojo que allí se encuentra. 

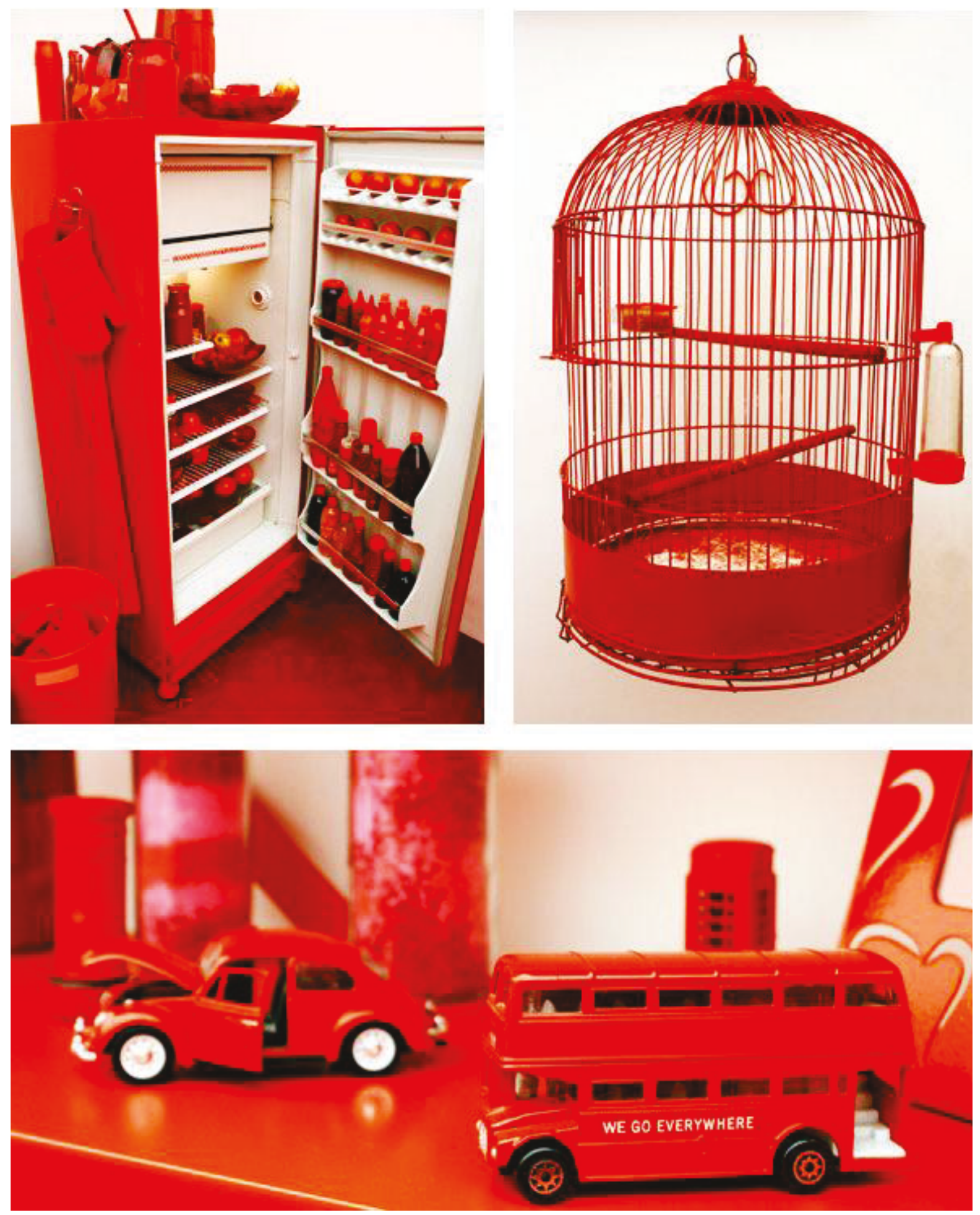

La segunda parte, Entorno (1980) (Figura 30), está formada por un charco de resina roja que aparenta salir de una minúscula botella caída en el suelo. Contenido y continente, dentro y fuera se relativizan. "El color parece haberse desprendido de las cosas para presentarse como tal: una densa rojura que 
termina inundando todo el recinto" (Rolnik, 2009). En relación a lo que expresa Rolnik, Ronaldo Brito señala que, si la impregnación cromática de la primera sala nos llevaba a dudar de nuestras retinas, en la segunda esa duda se magnifica y extiende a lo corporal.

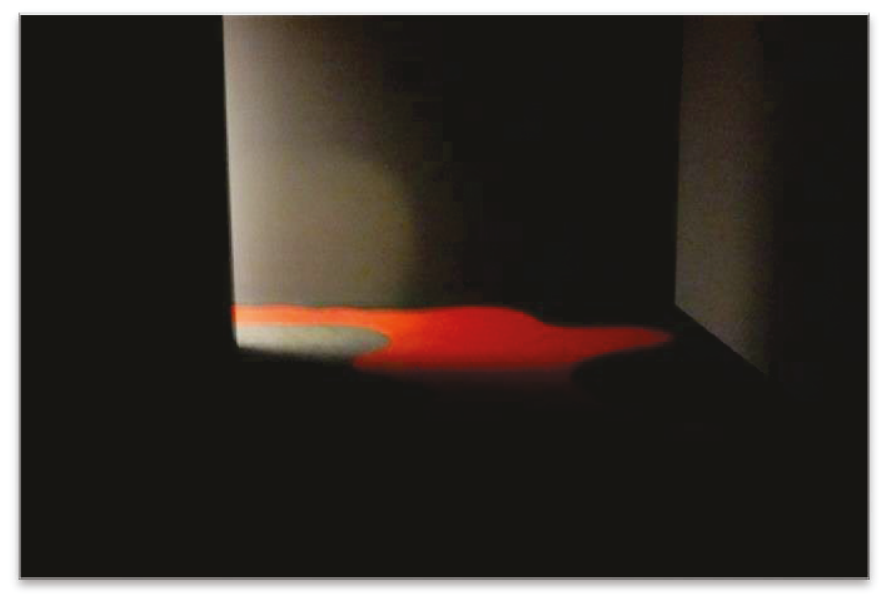

Figura 30 a y b. Desvío hacia el rojo. Entorno (1967-1984), de Cildo Meireles

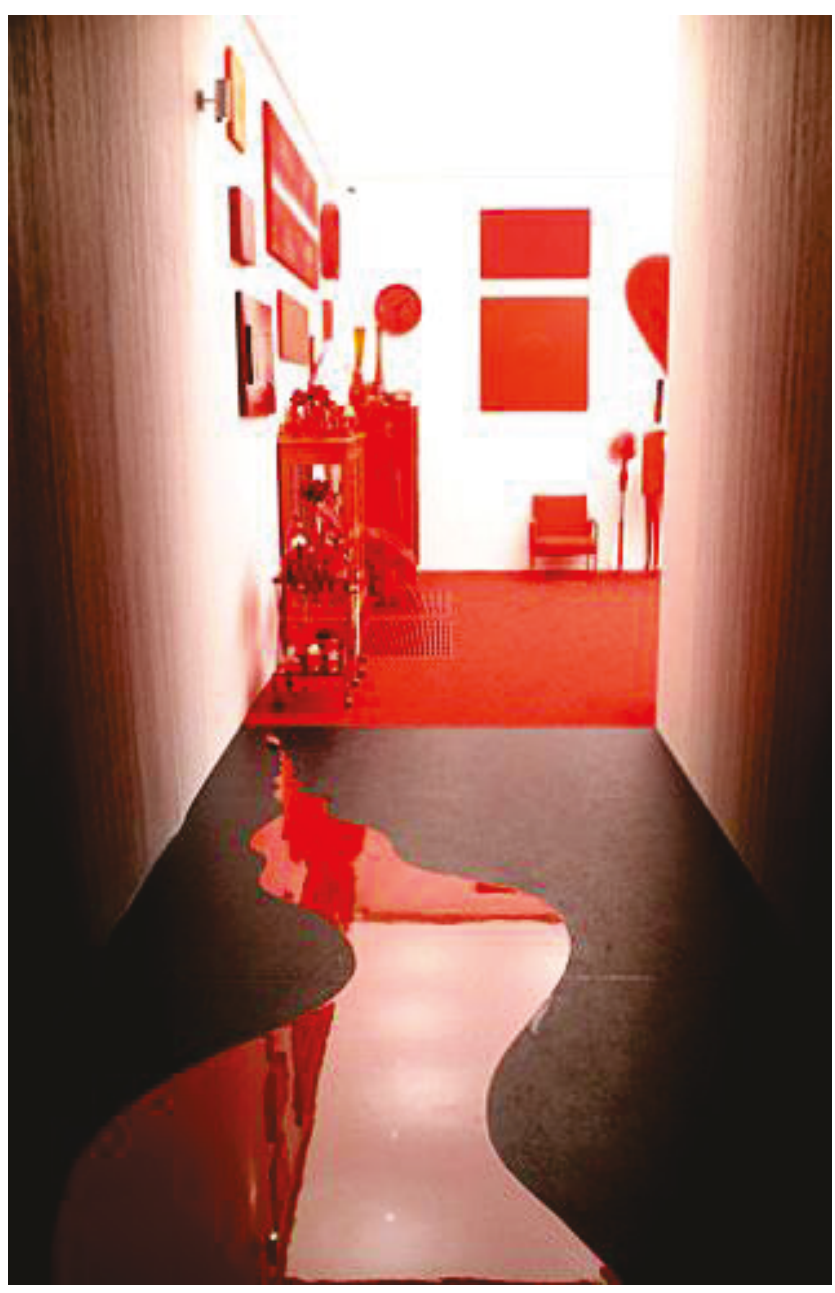


La tercera parte -Figura 31- es Desvío (1980) y está formada por un lavamanos blanco, que está inclinado unos $30^{\circ}$ con relación al suelo, en un espacio de completa oscuridad. La única iluminación, precariamente instalada, es el haz de luz sobre el lavamanos, de cuyo grifo sale continuamente un chorro de agua roja. Color y sonido se funden, finalmente, ese ese flujo incesante.

El color se pierde en una negrura absoluta. Se alcanza a ver un solo objeto al fondo de la sala [...]. Es un lavabo inclinado, como si fuese a caer, de cuyo grifo mana un líquido igualmente rojo que salpica toda la superficie. Es la única escena que soporta dramatismo; parece dar a entender que aquí hay una narración oculta (Rolnik, 2008).

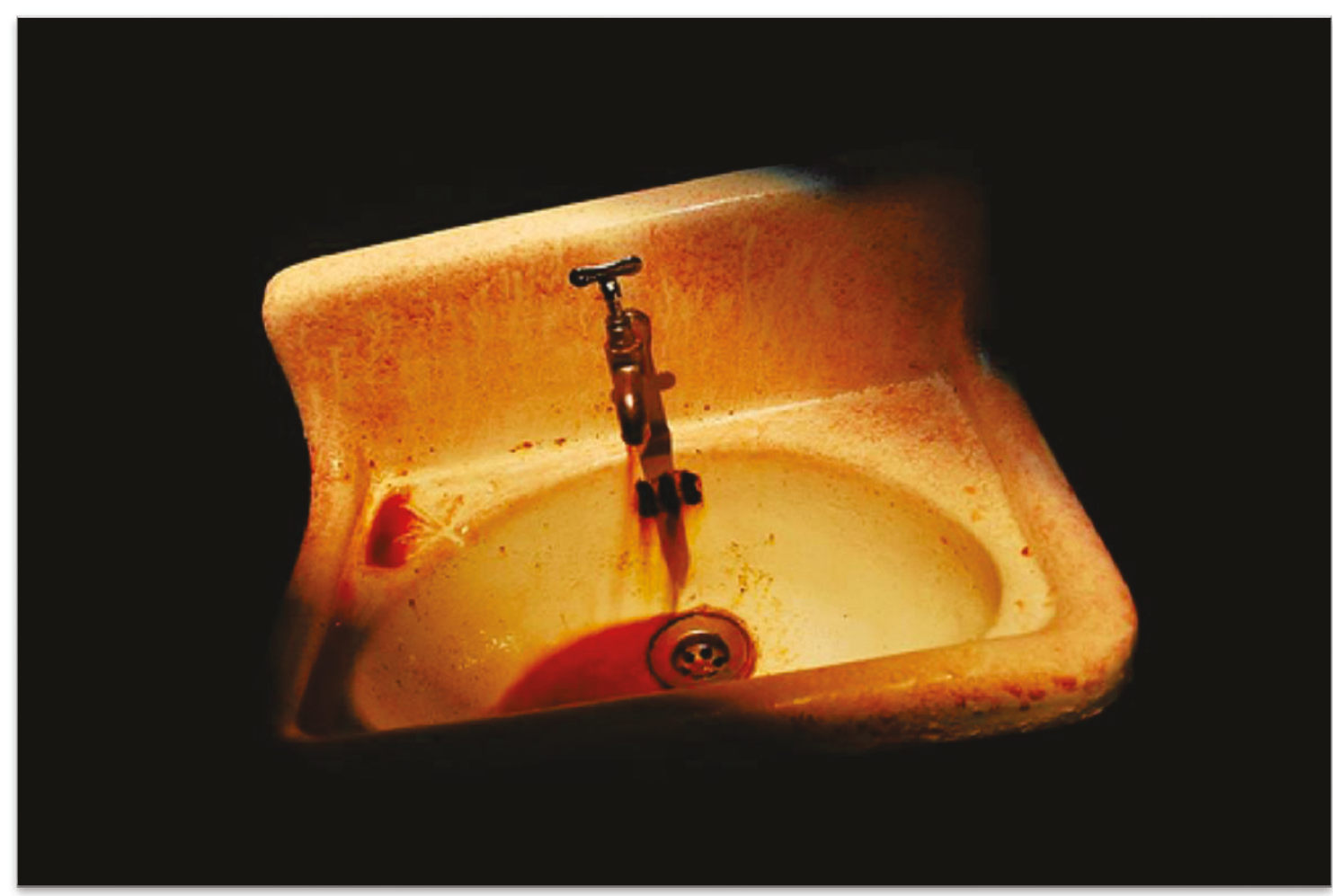

Figura 31. Desvío hacia el rojo. Desvío (1967-1984), de Cildo Meireles

Con Desvío hacia el Rojo Meireles estructura, para el espectador, una secuencia de impactos sensoriales y psicológicos, una serie de falsas lógicas a través de las que alude a múltiples símbolos y metáforas que permiten actualizar la noción de espectador descentrado. Las asociaciones a la violencia de la sangre y otras connotaciones ideológicas, así como la falta de correspondencia entre las partes y 
la dudosa ortogonalidad de la superficie sobre la que se transita, contribuyen en este sentido.

Meireles admite que la obra abre el juego a diversas lecturas políticas, pero relativiza esta perspectiva. Prioriza, en cambio, sus componentes físicos y poéticos. De este modo, considera a la primera parte (Impregnación), más que una metáfora, "un síntoma de un procedimiento de elección. Así como hay quien colecciona pipas, se pueden coleccionar colores, por qué no" (Brett, 2008). Las otras dos instancias sí tienen para el artista un componente más simbólico que instaura una cualidad circular: la mancha del segundo espacio y el grifo abierto del tercero ofrecen una explicación para el rojo de la primera, esto propicia una suerte de secuencia o de encadenamiento dramático, a la manera que refiere Kabakov.

La descripción en primera persona que ofrece Rolnik corrobora la coexistencia de un sujeto que está, simultáneamente, descentrado y centrado, tal como plantea Bishop. Descentrado, en tanto reconoce el desasosiego y la desorientación en que la sumerge la obra. Al respecto, Rolnik señala: "Poco a poco me voy perdiendo con relación a las referencias que aquellos objetos me ofrecieron tan pronto como entré allí [...] cada vez que la lógica parece tomar cuerpo, se deconstruye al paso siguiente" (Rolnik, 2008). Centrado, porque es capaz de un análisis racional y contextualizado de la génesis y de los recursos a los que apela el artista:

Nada que ver con una metáfora de la truculencia del régimen, en su cara visible y representable [...] sino con una sensación física de su atmósfera invisible que todo lo impregna [...]. La impresión es que por debajo o por detrás de una normalidad patológicamente excesiva que permea el cotidiano supuestamente ordinario de aquellas décadas bajo el terrorismo de Estado, está en marcha, días tras día, una sangría incesante de flujos vitales de la sociedad brasileña. Está todo tomado, como el rojo y el sonido del líquido que se escurre, que invade toda la instalación (Rolnik, 2008).

\subsubsection{El reconocimiento de la propia mirada: el espectador cómplice. Red room/Parents (La habitación del padre), de Louise Bourgeois}


La obra transitable implica un modo de percepción del espacio que se desplaza de la parte al todo y del todo a la parte, en un movimiento continuo. La obra se desenvuelve alrededor de ese espectador - visitante y lo incluye, dando lugar a una metamorfosis que lo convierte en espectador en situación, contextualizado, implicado en una contemplación dinámica que se origina en torno a su propio cuerpo.

Esta comunicación inusual desdibuja la frontera entre el sujeto y el objeto, y -en consecuencia- entre lo percibido y el que percibe, estableciendo planos de percepción de diferentes grados de intensidad (Alberganti, 2013: 121). Por eso este espectador/ usuario de la instalación no sólo habita el espacio de la obra sino que lo genera al incluirse en él, posibilitando una transición entre el espacio de la vida cotidiana y el espacio simbólico del arte. Al entrar a formar parte de aquello que es presentado como forma artística, actúa él mismo como arte, adoptando un doble papel: el de sujeto observador y el de objeto de representación:

De manera que el que mira, se mira a sí mismo, el que recorre se recorre y se reconoce en y junto a un determinado "discurso" que entra a formar parte de su propio re/conocimiento. (Larrañaga, 2001: 46)

En esta línea de reflexión, resulta significativo el caso de la obra de Louise Bourgeois Red Room (Parents), presentada en PROA en 2012. La habitación del Padre - traducción con que se conoció en nuestro medio - es una de las dos habitaciones claustrofóbicas realizada por la artista en 1994. Junto con Red Room, Child (Habitación Roja, Hijo/a), la obra reconstruye los escenarios traumáticos de la niñez de la artista y puede vincularse a la serie de Celdas que iniciara en 1991.

El término "cell" usado por Bourgeois reviste en inglés una ambigüedad difícil de traducir en nuestro idioma: refiere, por una parte, a la célula como unidad mínima de vida, fácilmente relacionable con el conjunto de formas embrionarias, germinaciones e imágenes de fecundidad habituales en su obra. Y por otro, alude a las celdas de la cárcel o de un monasterio. A través de estas obras manifiesta la ambivalencia que tiene para ella la casa como motivo artístico y sus múltiples metáforas, en que las celdas aparecen simultáneamente como guarida y como prisión. 
En una sala en penumbras, el acceso a la obra que nos ocupa revela una inquietante barrera circular formada por una serie de viejas puertas de madera antigua, entrelazadas, dispuestas en forma circular. El testimonio en primera persona de la artista Lihuel González sobre su experiencia con la obra contribuye a facilitar su comprensión:

Rodeé la instalación tocando la superficie de las puertas y espiando por las rendijas empecé a reconstruir el cuarto a través de los fragmentos. Me sentí una voyeur obsesionada con una escena ajena que no tardaría mucho en hacer propia (González, 2014)

Un pasaje estrecho entre dos paredes curvas permite observar un poco más de cerca la escena en el interior del cuarto, aunque buena parte de él continúe vedado: una delgada cinta impide seguir avanzando, por lo que el interior sólo puede ser aprehendido a través del reflejo en un espejo oval. Así se descubre en el centro una cama matrimonial de color rojo bermellón, cuya superficie es la de un tablón de madera, duro, incómodo. Sobre ella descansan un tren de juguete y la caja de un instrumento musical; en la cabecera, dos almohadones igualmente rojos, y entre ellos uno blanco y pequeño bordado en letras rojas con la frase "Je t'aime"; frente a la cama se sitúa el espejo que refleja la escena y que es nuestra puerta de acceso a ese interior tan habitual como siniestro.

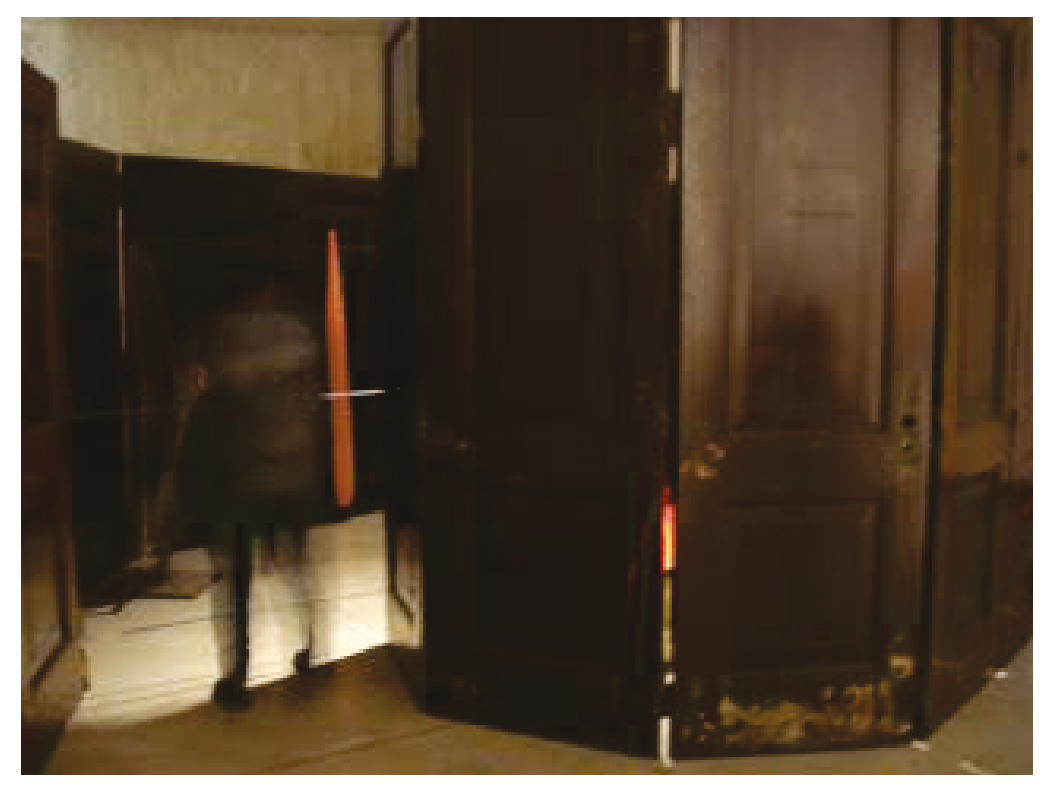

Figura 32: Acceso a Red Room/Parents en PROA (2011) 
Reconstruyendo el espacio se descubren una estructura blanda, de aspecto orgánico, que cuelga del techo y un objeto resinoso color rubí, en parte transparente, atravesado por una aguja que cuelga sobre la cama. A los lados de esta, sobre dos mesas casi idénticas, pueden observarse dos esculturas cubiertas por un velo endurecido que remiten a cuerpos inertes y confieren a la habitación el aire de la escena de un crimen.

Y tuve la sensación de que se trataba de algo (...) viejo y doloroso suspendido sobre la cama de los padres (...) Tuve una sensación de violencia. Pensé en todo lo que se escondía detrás de la escena (...). Comencé a hilar las partes, sentí que había algo esencial escondido que parecía siempre a punto de revelarse. El cuarto estaba cargado de una presencia que me transportó a otro tiempo. Supongo que por un momento me vi escarbando viejos recuerdos. Todo gira alrededor de lo oculto, velo sobre velo de algo que se escapa y que finalmente no podemos ver (González, 2014)

Figura 33: Acceso a Red Room/Parents en PROA. CABA. (2011) 

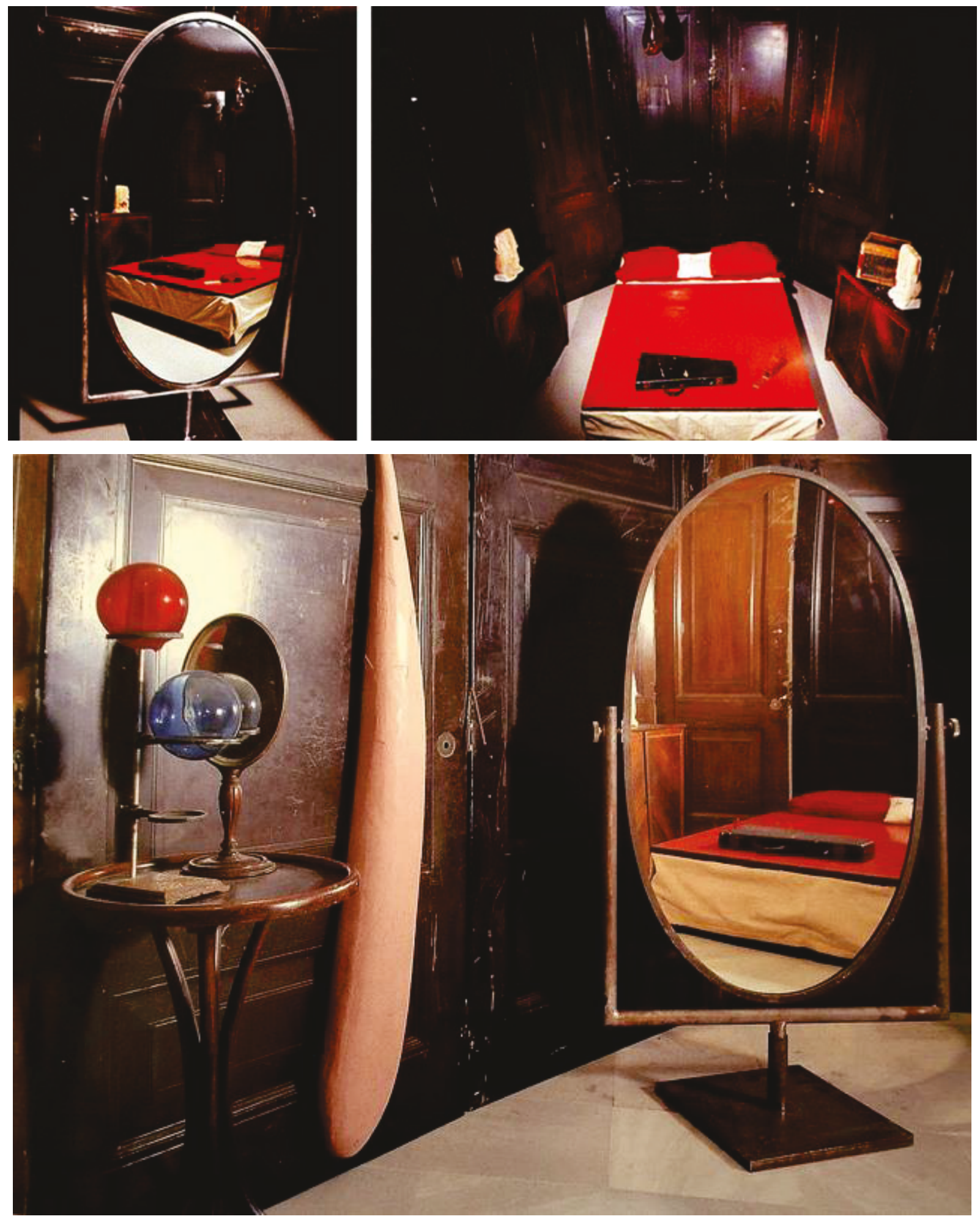

Figuras 34, 35, 36 y 37: Vistas parciales de Red room (Parents). La habitación del padre, de Louise Bourgeois en PROA. CABA (2011) 


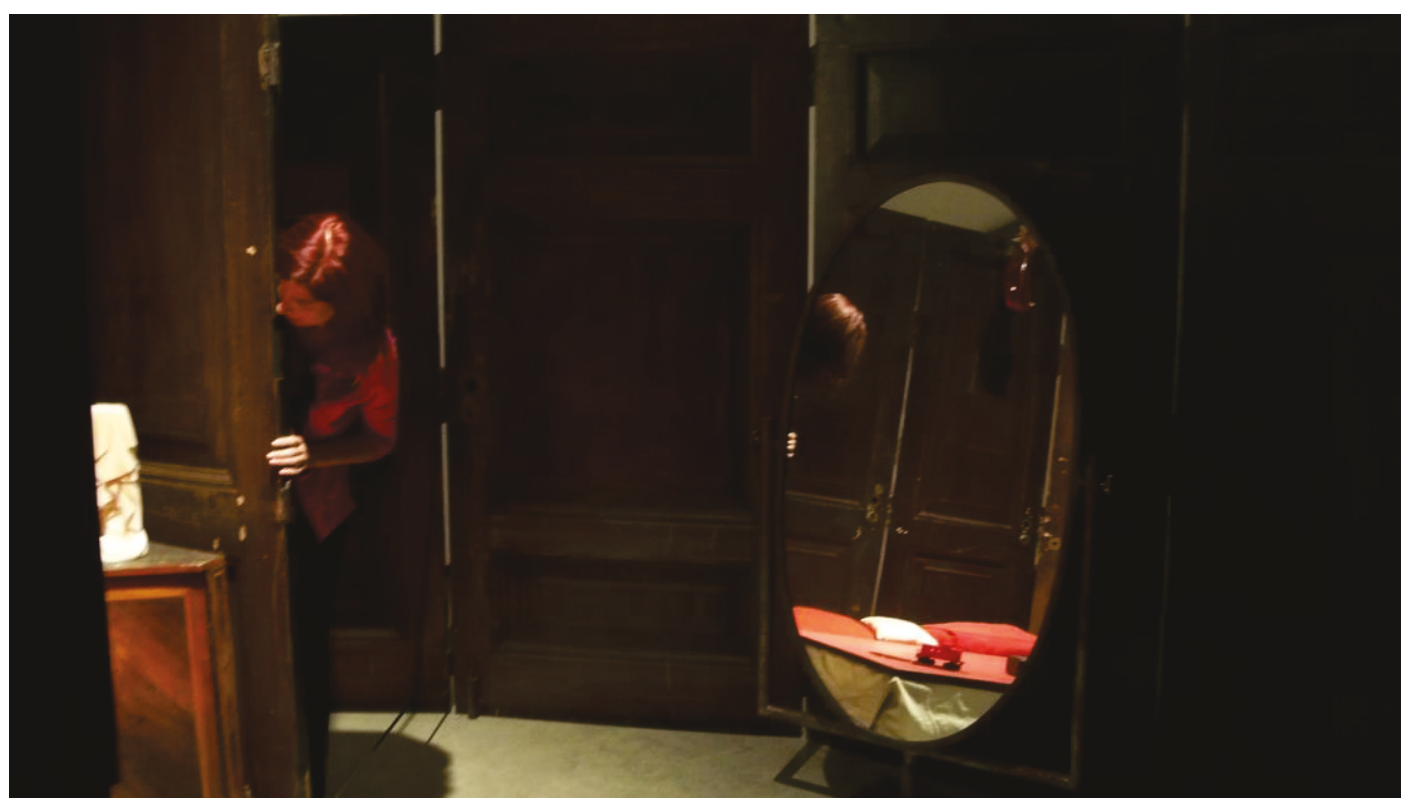

Bourgeois asocia frecuentemente en sus obras el color rojo a la violencia, la sangre, los celos y la culpa. Por eso las habitaciones de Red Rooms aparecen como reconstrucción del drama del adulterio que amenaza con destruir el equilibrio familiar, pero representan también la perturbación de la mirada infantil frente al universo prohibido de la habitación de los padres (Mayayo, 2002: 71), cuyo impacto psicoanalítico escapa a los alcances de este trabajo.

Lo que hace de esta una obra brillante desde el punto de vista que abordamos en este escrito, es observar cómo la sencilla modulación espacial que propone la artista, obliga al espectador a compartir la experiencia de asomarse a lo prohibido y de algún modo encarnarse en cómplice, actitud que es revelada al encontrarse a sí mismo como espía en la imagen del espejo.

\subsection{El espectador / ¿actor?}

La experiencia individual y el recorrido elegido por el espectador contribuyen a conformar el propio contenido de la obra. Por eso, en la medida en que actúa, "pone en representación los elementos y espacios propuestos por el artista, se representa con ellos y entre ellos" (Larrañaga, 2001: 46). De esta forma el 
individuo no sólo construye y otorga una envoltura figurativa al lugar, sino que también, al habitarlo, lo dota de un propósito particular y de un valor simbólico.

Podemos decir entonces que la experiencia receptora consiste, más que en el descubrimiento de unas relaciones formales más o menos estructuradas, en la concientización de las relaciones que se establecen entre la obra, el propio cuerpo y el contexto.

Claro que el grado de participación estará determinado por cada propuesta, y la inclusión del espectador en el proceso creativo asumirá contornos particulares en cada caso. Pero podemos afirmar que en cualquiera de ellos, la respuesta posible ya no será simplemente un desplazamiento o un modo determinado de aproximación al objeto, sino la imagen de ese movimiento $y$, sobre todo, la conciencia de esa relación fluctuante entre el sujeto y del objeto.

Al mismo tiempo, en su recorrido este espectador se ve confrontado con otros, cuyas presencias aportan nuevos intersticios en la lectura de la obra. Por eso, en la instalación, más que de espectador o de público, podemos hablar de un habitante e incluso de un actor, ya que en ella, tal como sostiene Teresita Aninat

[...] los cuerpos logran un proceso comunicativo, de intercambio social de significados. En esta comunicación, el lugar adquiere referencias teatrales al convertirse en un escenario de intercambio para los habitantes que le ocupan (Aninat, 2004).

Larrañaga entiende que -como puesta en escena-, la instalación actúa en sentido contrario al sistema de exposición propio del arte, en el cual un cuadro sobre el muro o una escultura sobre un pedestal, genera una ruptura entre el espaciogalería, el objeto-obra de arte y el sujeto espectador. Por el contrario, la instalación se sustenta en criterios de convergencia y relación, por eso se hace posible entender a los objetos como parte de una trama cuyo activador es el espectador. De esta manera, la idea de exposición se abre a las de intervención, acción o actuación. (Larrañaga, 2001: 59). En el mismo sentido, Teresita Aninat señala que:

(...) pareciera que en la instalación se establece un sistema de vínculos dado por nuestra situación como espectadores que habitan y recorren la obra (o al menos circulan entre ellas), dado por la situación de la obra con respecto al lugar al cual debe adaptarse en su montaje y dado 
por la situación del lugar al momento de situarse la obra. Estos vínculos asemejan la situación de una instalación a una obra dramática, en las cuales un personaje afronta un conflicto. La situación posee a su vez un "aire teatral". (Aninat, 2006: 34-35)

Como señalábamos anteriormente, cuando el espectador-visitante penetra en la obra se sumerge en una situación ficcional, que construye un efecto de realidad particular. Claro que no se trata, en sentido estricto, de una acción performática en la que el cuerpo deviene soporte material de un acontecimiento; pero sí puede equipararse con una suerte de performance íntima, intransferible, del receptor (Oliveras, 2000). De esta forma, no sólo construye la envoltura figurativa del lugar, sino que, al habitarlo, lo dota de valor simbólico, lo ritualiza y lo construye como escenario.

\subsubsection{Cuando la mirada del otro construye al actor: Migrantes, de Christian Boltanski.}

Se hace oportuno retomar aquí el caso de Migrantes (2012), la obra de Christian Boltanski en el Hotel de Inmigrantes con la que fue posible abordar las particularidades de las obras de sitio específico.

Resulta significativo en este caso, que consideramos paradigmático en todos los aspectos del análisis que hemos ido formulando a través de este trabajo, la posición simple y descentrada del artista. En el catálogo de la muestra se refiere a su punto de partida, a la lógica que articularía la totalidad de esta muestra: "Lo único que puedes hacer aquí es un collage con este lugar y con la historia de este lugar". (Weschler, 2012)

Lo que hoy llamamos Hotel de Inmigrantes fue el último de los edificios terminados como parte de una ciudadela proyectada hacia fines del Siglo XIX, en el marco de la política inmigratoria de puertas abiertas concebida en la época por el estado nacional22. El proyecto, que se inauguró oficialmente en 1911, contaba, además,

22 El complejo edilicio se emplazó en un terreno aislado de la ciudad de Buenos Aires, en Dársena Norte. Los pabellones se organizaron alrededor de una plaza central. A lo largo de la costa estaba el desembarcadero; sobre el frente, la dirección y las oficinas de trabajo; a continuación, los 
con un desembarcadero, un hospital y con oficina de correos y de trabajo. Tenía por objetivo procurar asistencia social a los recién llegados y posibilitar desde el Estado argentino una organización con estrategias de control y de registro sobre los nuevos habitantes, a efectos de ordenar el impacto inmigratorio.

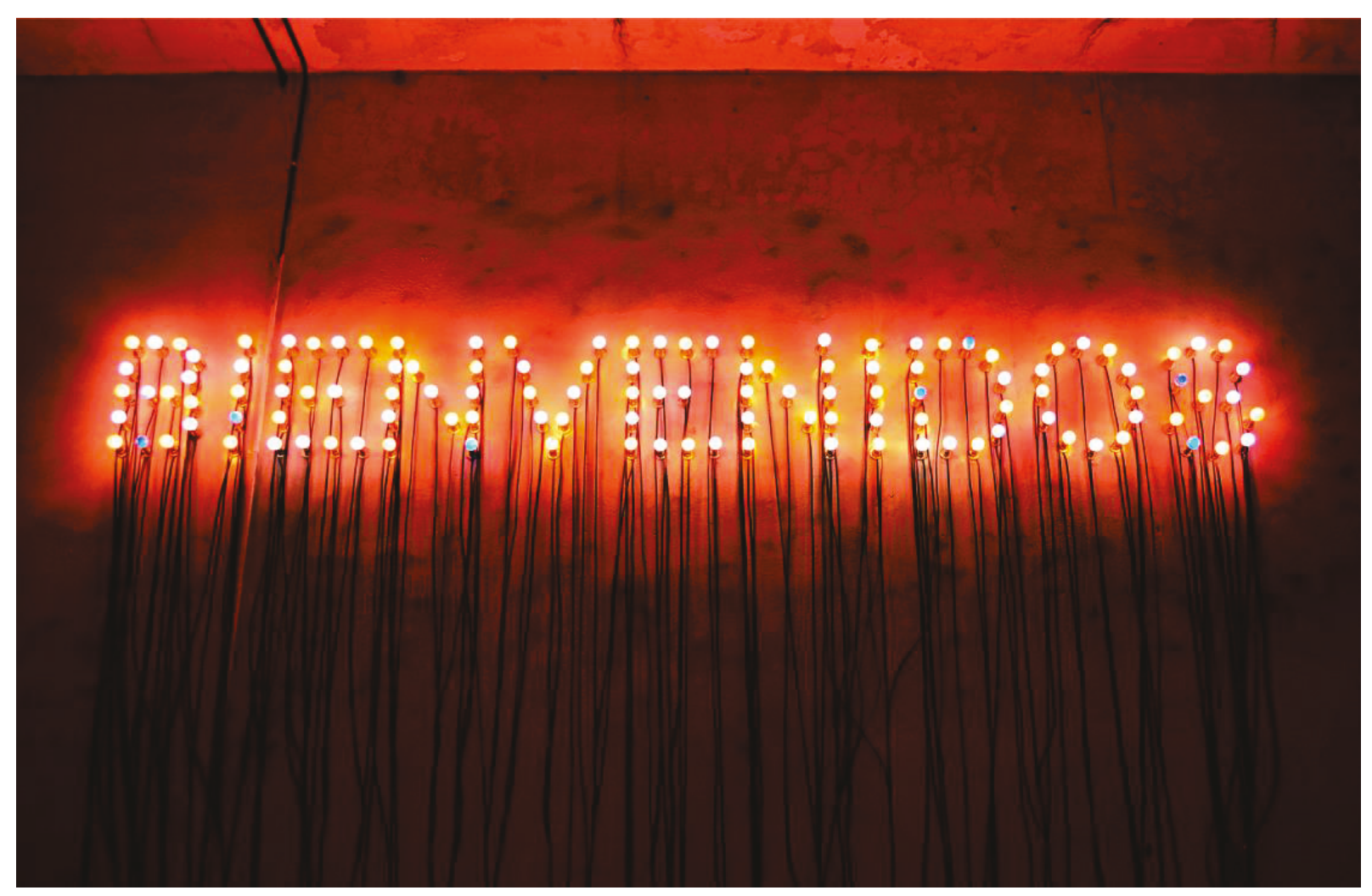

Figura 38. Migrantes, de C. Boltanski, en el Hotel de Inmigrantes (2012)

El sociólogo Sebastián Russo reconstruye el clima de la vida en el hotel y la entrecruza con su propia vivencia de la obra:

La idea del hotel suponía tiempos de espera; de localización de equipajes, de gestión de documentos [...] cruces de historias compartidas durante el viaje en barco (generalmente desde puertos

\footnotetext{
lavaderos, y cerrando el perímetro, el edificio que albergaba los dormitorios y el comedor. Este último, desarrollado en cuatro plantas, adquirió con el tiempo el nombre del conjunto, Hotel de Inmigrantes, y comprende un gran rectángulo de 100 metros de largo por 26 metros de ancho, de líneas rectas, volumen simétrico y una sobria ornamentación.

En la planta baja estaban el comedor y la cocina; los dormitorios se encontraban en los pisos superiores, cuatro por cada planta, con capacidad para 250 personas cada uno. Una doble hilera de ventanas y la circulación longitudinal, ventilaba e iluminaban estos espacios. Los servicios sanitarios, exteriores al edificio, reflejan un criterio de la época.
} 
europeos), la mezcla de idiomas y culturas; la búsqueda de trabajo; los aprendizajes a toda velocidad del nuevo idioma, de oficios varios, apropiados para la nueva circunstancia; el deseo de una vida nueva y la memoria, muchas veces dolorosa, del pasado inmediato que se estaba dejando atrás. Momentos de cambio y excepcionalidad, momentos de tiempo en suspenso, combinaciones de vidas particulares y fenómenos sociales (Russo, 2012).

La obra de Boltanski, que ocupó la tercera planta del edificio original, tomó como punto de partida los archivos del Museo: nombres, edades, ocupación y fecha de llegada de los huéspedes, extraídos de los propios registros, son leídos por más de 500 voces en el idioma original y, al superponerse, configuran una suerte de murmullo, que es el primer dato que el espectador advierte y que lo acompaña durante todo el recorrido. Diana Wechsler, la curadora del proyecto, explica en el catálogo de la muestra: "Este 'susurro', acompañado por una atmósfera neblinosa, tenuemente iluminada, introduce al visitante en una experiencia que lo conecta con la memoria y el pasado de nuestra sociedad y a la vez con el de la propia historia" (Wechsler, 2012). Asimismo, Russo comenta al respecto:

Un murmullo agobiante, entremezclado, de voces que se embadurnan en sus idiomas disímiles, se oye en y desde todas las salas. Un murmullo continuo y heteróclito, insoportable para una lógica estatal de afán a la vez homogenizador $y$ distinguidor, aglutinador $y$ catalogador del diferente, con las técnicas heredadas de la criminalística lombrosiana y el higienismo (Russo, 2012).

En torno a la escalera de mármol que permite el acceso a la instalación, el edificio conserva aún un aire de hospital, con ventanas altísimas y paredes de azulejos blancos, que remiten al paradigma higienista que, a fines del Siglo XIX, reemplazó al de civilización o barbarie.

El pasillo de circulación longitudinal del tercer nivel funciona como eje articulador. La exhibición se construye con mínimos recursos técnicos (apenas un reflector en cada extremo y unas máquinas de humo), generando una niebla densa que juega con el contraluz; de este modo, el público que deambula por el larguísimo pasillo es, para los otros visitantes -como se puede ver en la Figura 38-, un personaje que emerge de la bruma, una figura espectral, un fantasma. La profundidad aumenta con una sucesión de sobretodos negros que están colgados a distintas alturas al final del recorrido; prendas también rescatadas del Museo y del olvido, con las que habitualmente el artista construye su metáfora sobre lo transitorio de 
la existencia humana. Eduardo Grüner define a la representación como la presencia de una ausencia. Ese espesor de significaciones constituye el núcleo de la obra de Boltanski: "Mi materia, aunque parezcan formas diferentes, es siempre la misma. Se trata de un objeto que remite a un sujeto ausente", señala el artista.

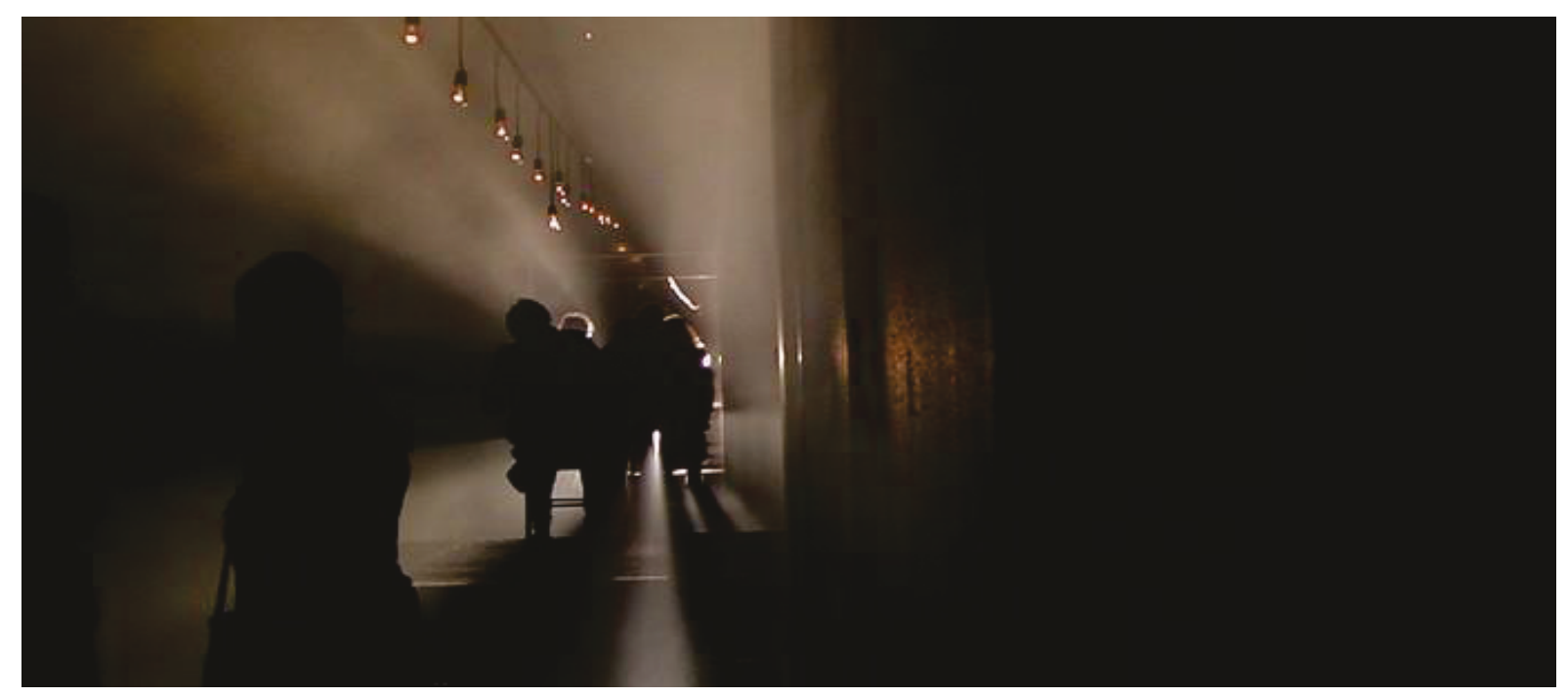

Figuras 39 y 40. Migrantes, de C. Boltanski, en el Hotel de Inmigrantes. Vista del pasillo central de la instalación, con circulación de público

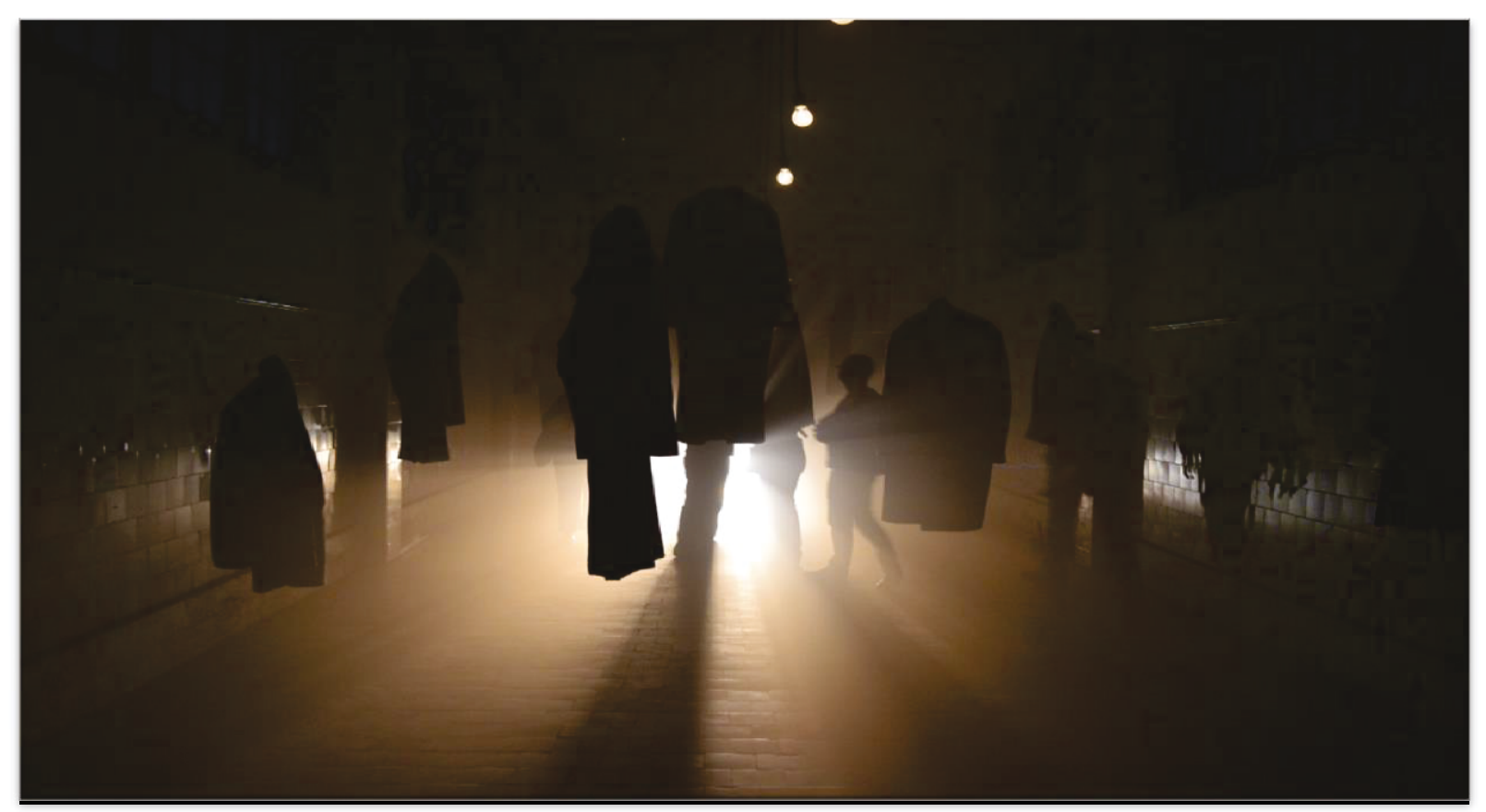


Sacos alineados, camas vacías, zonas ocultas, sectores tenuemente iluminados; todo ellos, elementos que refuerzan su condición de obra de sitio específico y que involucran, necesariamente, una reformulación de relaciones de coexistencia entre los elementos de un lugar. A partir de este supuesto, Boltanski entreteje en la obra la doble dimensión que toda migración supone: por un lado, la apuesta esperanzada ante una nueva vida, y por otro, "el temor ante una tierra que lo convoca pero que a su vez lo repele, ante la sospecha y la aprensión por la mezcla, la peste, el virus (menos biológico que social), que lo convierte de visitante anhelado a peligro inminente" (Russo, 2012). Esta tensión se actualiza en la instalación de Boltanski, quien explicó en una entrevista su primer encuentro con el espacio de esta forma:

Me impresionaron los pisos donde están los archivos. Recuerdo que vi que estaban todos los papeles sobre el piso, apilados. Miles y miles de vidas... Hay tanta gente, hay tantas historias, acumuladas en este lugar... Algún tuberculoso, alguno que dejó a su novia para venir a América... Hay miles de historias. Recuerdo, también, que había tanto polvo entre los papeles, que tenía los ojos enrojecidos. Estaba toda esa masa de historia devenida una forma de polvo, digamos (Pérez Bergliaffa, 2012).

Los antiguos dormitorios, simétricamente dispuestos, articulan una narrativa general. La primera sala a la derecha está modulada con una sucesión de sábanas blancas tendidas, tal como se observa en la Figura 41. En cada una hay una imagen pixelada, impresa en blanco y negro. Una mirada; miradas distintas, extrañadas, expectantes. La iluminación es pobre, con lamparitas de tungsteno con el cableado a la vista, y en la pared hay un cartel de bienvenida, escrito con luces de neón (Figura 38). 


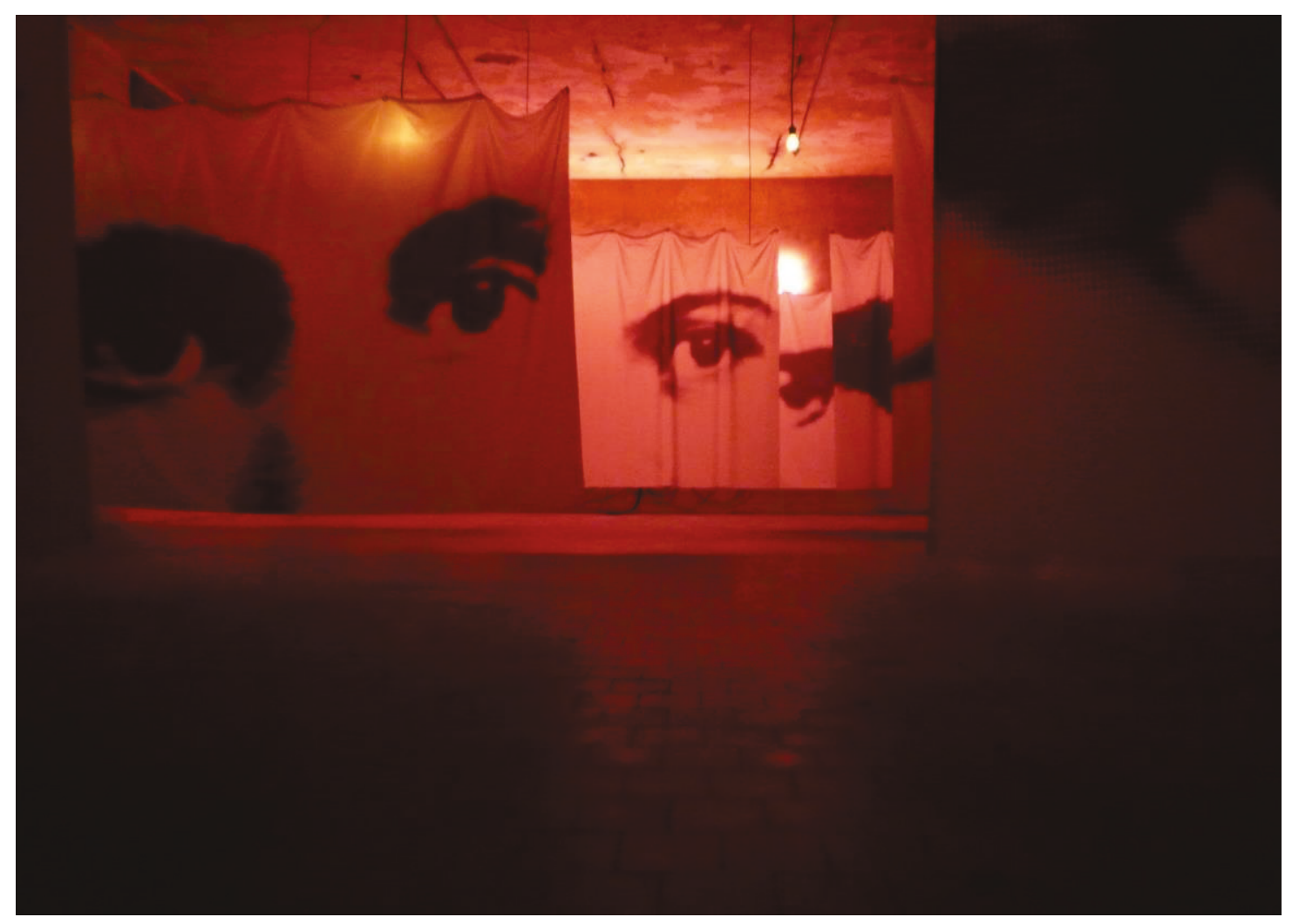

Figura 41 a y b. Vista parcial de la sala con sábanas impresas

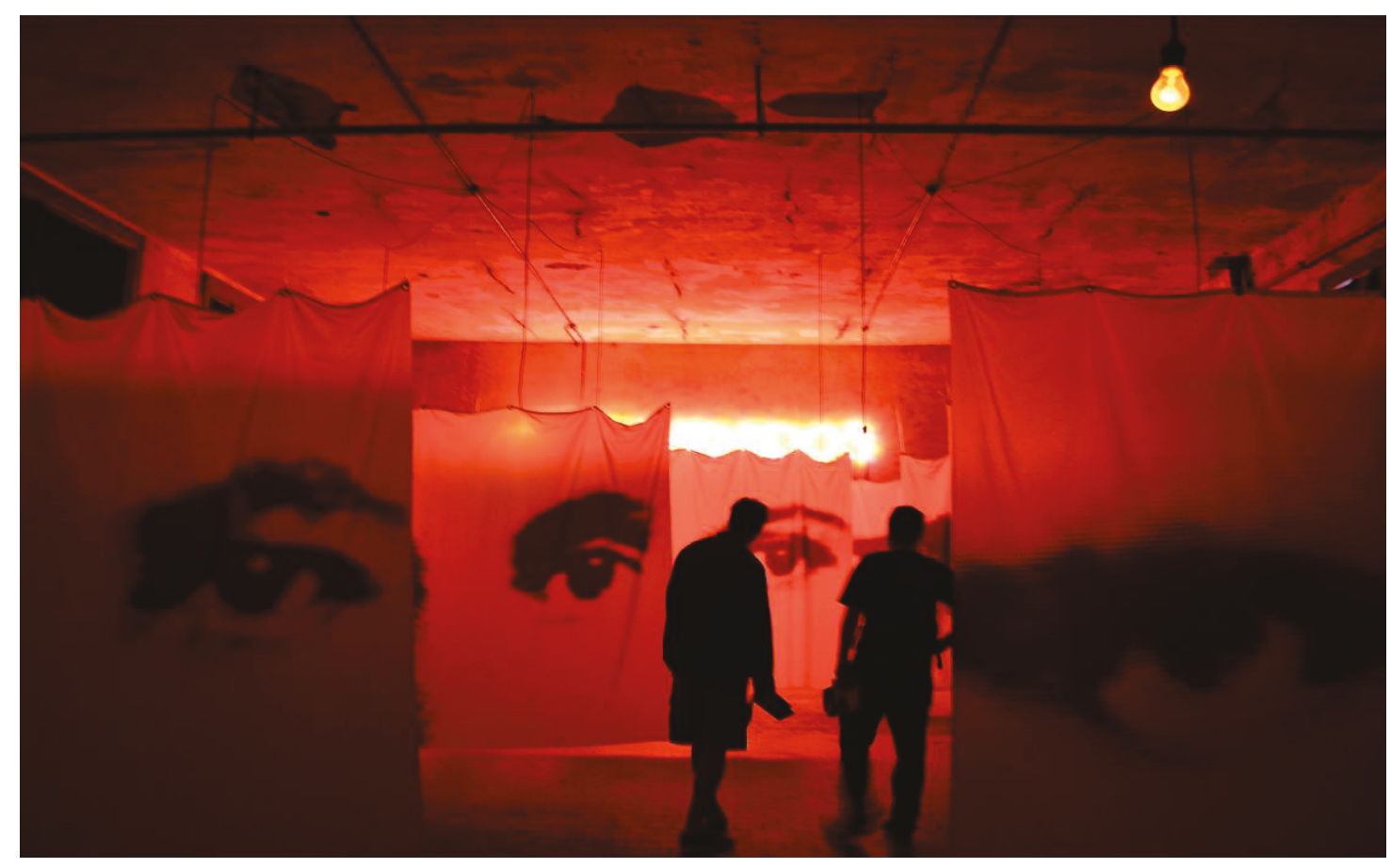



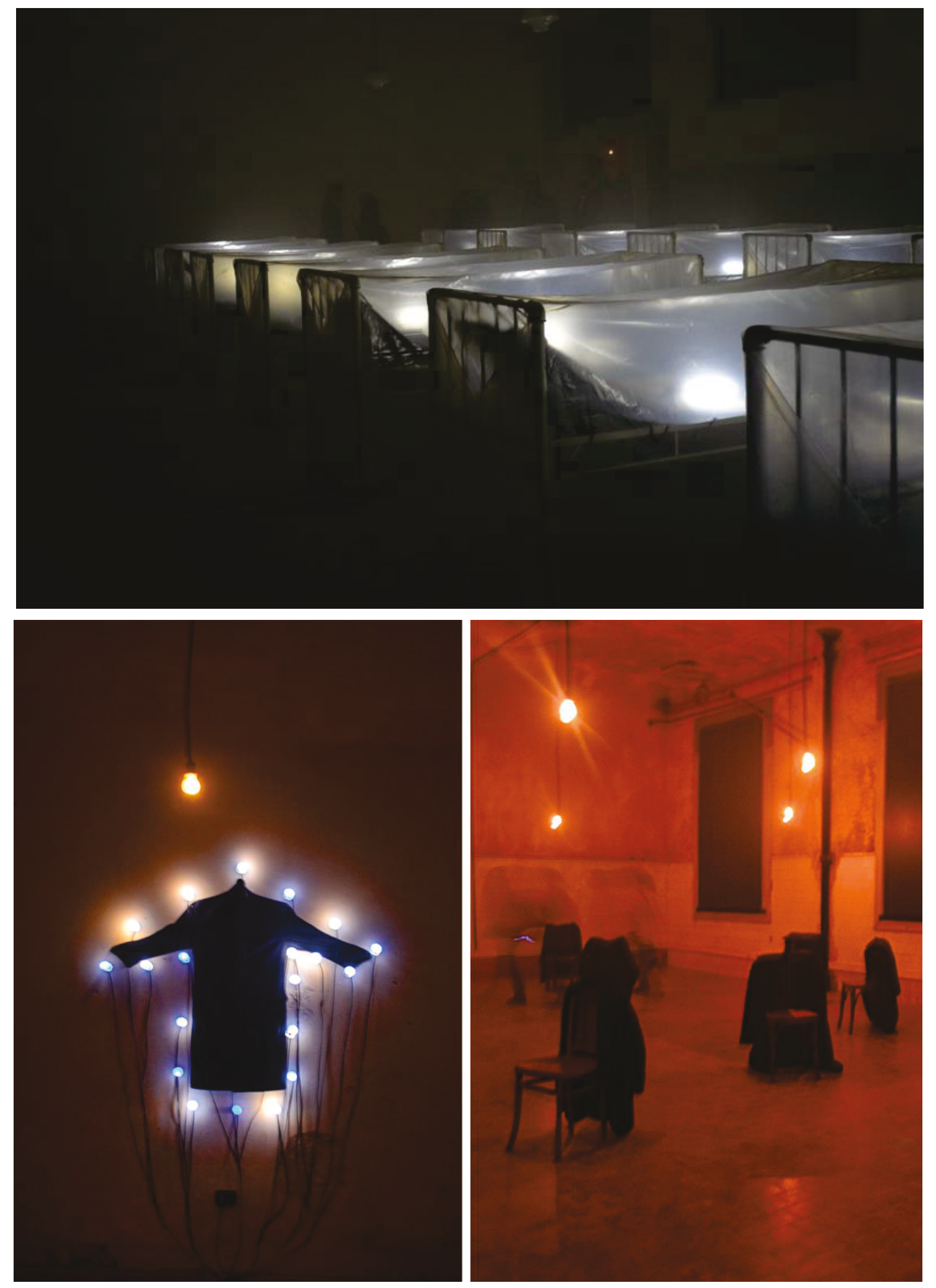

Figuras 42,43 y 44 . Vistas de dormitorio y reclinatorio. 
En la segunda sala los elementos que se repiten son las sillas. Están dispuestas en diagonal, paralelas entre sí; un sobretodo negro cuelga de cada respaldo. En la pared del fondo hay otro saco similar, con los brazos abiertos en cruz y rodeado de bombillas. Las sillas y los sacos se reconocen, entonces, como personas arrodilladas, y la sala, como ámbito de fe.

A la izquierda del corredor hay dos salas: en una de ellas se ven dos hileras de camas de hierro, iguales, dispuestas simétricamente. Tal como se refleja en la Figura 42, las camas del Hotel, con lonas tensadas con sogas, a modo de colchón, envueltas en nylon e iluminadas desde adentro con luces frías, recrean un clima que vuelve a hacer presente el paradigma higienista.

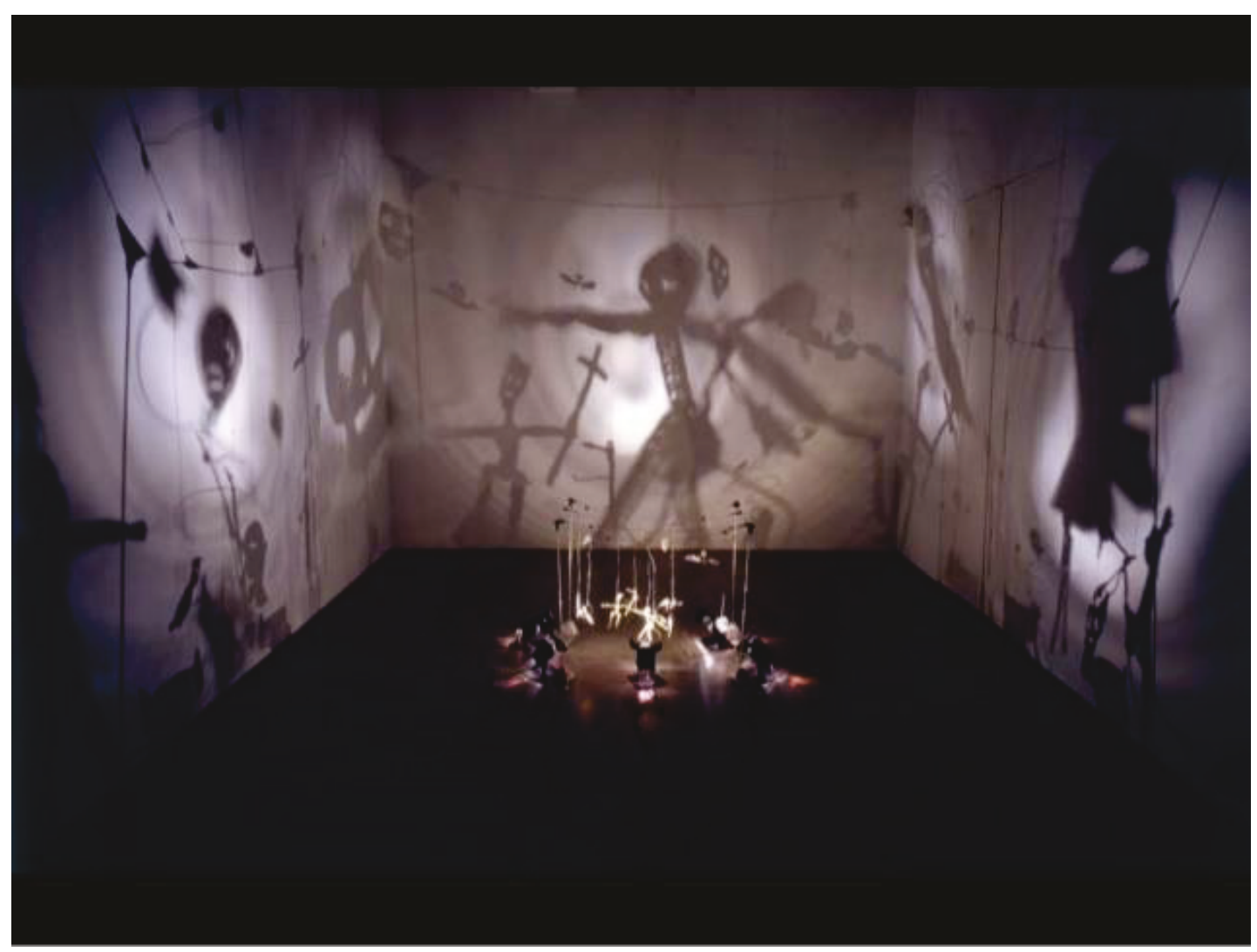

Figura 45. Escena de figurillas y proyección en teatro de sombras

La otra sala es radicalmente diferente a las anteriores: es una sala cerrada. A través de los vidrios de la puerta pueden observarse pequeñas figuras, ásperas y grotescas, cuya proyección sobre el plano de fondo genera una especie de danza 
macabra. La instalación tiene un aire siniestro -como se ve en la Figura 45-, que se mezcla con cierta resonancia infantil producida por la sencilla técnica del tradicional teatro de sombras al que recurre. En la Figura 46 se refleja el espacio transversal, a ambos lados del pasillo, en el que se ordenan -en semicírculopercheros con sacos negro colgados, uno por cada perchero, también con fundas de transparentes, e iluminados con luces frías. Alrededor hay largos asientos de material -los asientos del Hotel- que hablan de tiempos de espera. Y a la izquierda, en una oscuridad casi absoluta, una especie de mesa o mesada, con una superficie irregular, también envuelta en nylon. El olfato, más que la vista, permite dar cuenta de que debajo hay flores muertas.

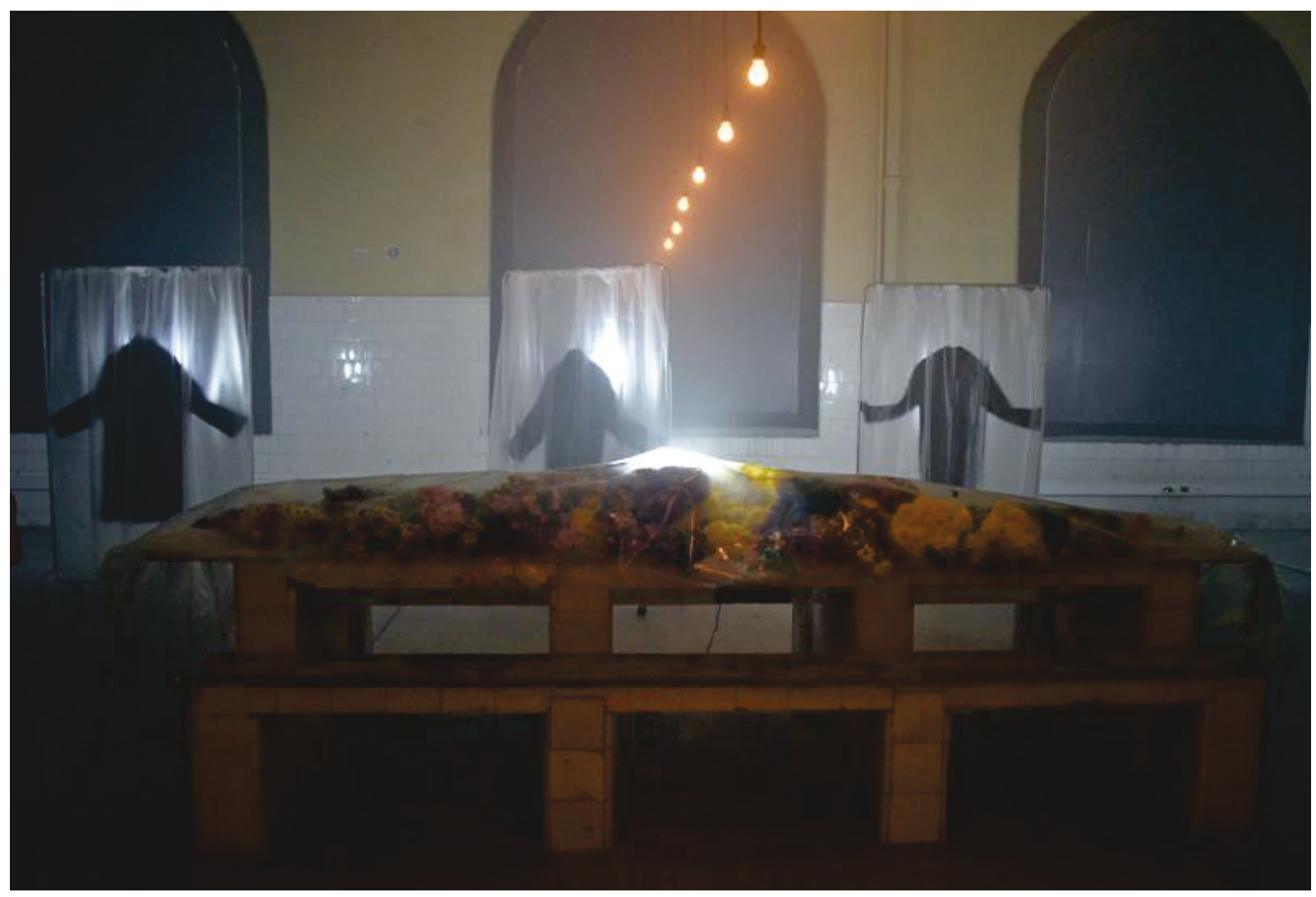

Figura 46. Ronda de percheros intervenidos

Migrantes articula una experiencia compleja: el espectador se ve incorporado en una situación que atraviesa no sólo una dimensión estética y simbólica, sino que involucra saberes, identidades y memorias tanto personales como colectivas muy 
profundas. La narrativa que la obra construye lo lleva a encarnar -con sólo recorrer esos espacios, exponiéndose a la mirada de los otros- la presencia de sus ancestros ausentes, y la posibilidad inquietante de prestar el propio cuerpo a esas visiones de otro tiempo.

La posibilidad de circular dentro de la obra, entre camastros, viejos sacos colgados y parapetos higienistas, acompañado por las voces que se entremezclan y superponen, y que van imponiéndose unas sobre otras en relación al propio recorrido, da lugar a la construcción de un diálogo singular "con esos (nuestros) espectros, que agobian los vetustos salones, así como agobian en nuestras cabezas nuestros muertos" (Russo, 2012).

Por eso Víctor Zamudio -Taylor dice que en la instalación, el recurso de la alegoría opera como manera de representar la historia de modo resumido y a la vez fragmentado, permitiendo articular el pasado de manera vital.

Su impacto en el presente se percibe vivo y no petrificado ya que la carga simbólica de los materiales y de la ambientación[...] es dinámica, movediza, porosa y abierta, acumulativa de lecturas no lineales y narrativas interrumpidas (Zamudio-Taylor, 2006).

\subsection{La instalación y el aura.}

El caso desarrollado nos conduce, irremediablemente, a repensar la dimensión de lo aurático en el arte contemporáneo. Y curiosamente, establece puntos de contacto con lo que propone Ticio Escobar, cuando analiza la escena de la representación ritual en las culturas originarias. En estos casos señala al espacio ceremonial o ritual como determinado por una línea invisible que preserva la distancia y que abre el juego de la mirada. Con sólo atravesarla, "los objetos y los hombres se desdoblan. Ya no coincide cada cual consigo mismo, y más allá de sí, deviene oficiante, dios o elemento consagrado" (Escobar, 2004). Este proceso de auratización es de tipo conceptual, ya que responde al hecho de saberlos emplazados dentro de un espacio diferenciado que los separa del mundo cotidiano y los ofrece a la mirada. Escobar enfatiza en que es la inscripción lo que inviste de aura al objeto, independientemente de sus valores expresivos o formales, desde una posición afín a la que asume Boris Groys cuando alude a los 
procesos de desterritorialización y reterritorializaición en el arte contemporáneo, que lo llevan a definir a la instalación como un proceso de selección, una concatenación de opciones posibles, una determinada lógica de inclusiones y exclusiones, que rescata imágenes y objetos de nuestra cotidianeidad para inscribirlos en un espacio diferenciado, "que hace explícita su condición de verdad" (Groys, 2008).

Con las instalaciones, los vínculos entre original y copia han sido replanteados: porque aunque el modo de trabajo y los materiales la vinculan con lo reproductible, mantiene intacta una "vocación de singularidad" (Larrañaga, 2001). Como práctica que reclama la experiencia individual y presente, localizada en un aquí y ahora que determina una vivencia irrepetible, la instalación se inscribe como un arte de tintes auráticos, pero "sin participar de las notas que fundamentan el privilegio exclusivista del aura ilustrada" (Escobar, 2004). Pero Groys señala que la diferencia entre original y copia se reduce, en este caso, a una cuestión topológica y situacional:

Los componentes de una instalación son originales por una sencilla razón topológica: hace falta ir a la instalación para poder verlos. La instalación es, ante todo, una variación socialmente codificada de la práctica del flaneur (flaneurship), como la describió Benjamin, y por tanto, un lugar para el aura, para la "iluminación profana" (...) Más bien la época moderna organiza una compleja interacción de dislocaciones y relocalizaciones, de desterritorializaciones y reterritorializaciones. Lo que distingue al arte contemporáneo del de momentos anteriores es sólo el hecho de que la originalidad de una obra de nuestro tiempo no se establece de acuerdo a su propia forma, sino a través de si inclusión en un determinado contexto, en una determinada instalación, por medio de su inscripción topológica (Groys, 2008).

De este modo, la instalación articula - junto a las tensiones que se establecen entre los objetos que la componen - asociaciones complejas, analogías culturales o cotidianas y memorias personales. Y junto con el condicionamiento topológico, este particular modelo de recepción que profundiza en la idea de una experiencia singular e irrepetible. 


\section{CONCLUSIONES}

Si a lo largo del siglo XX la producción artística se fue transformando en un

proceso de selección, articulación y presentación de diversos componentes, la instalación fue configurándose como un emergente de esa compleja operación. Por eso en nuestros días ha dejado de ser relevante todo intento por definirla como género o medio preponderante, en tanto se ha consolidado como un soporte espacio-temporal preferencial y mayoritario, parangonándose con la manera habitual de ser de lo artístico en el marco de la cultura contemporánea.

Es posible pensar que los esfuerzos tempranos por definirla resultaron infructuosos por la misma naturaleza de la práctica, que parece desafiar permanentemente sus propios límites: las constantes mutaciones que produce en su interrelación con otras disciplinas, materias y discursos, redundan en una permanente metamorfosis de sus alcances.

Sin embargo, es posible concebirla como una práctica interdisciplinar capaz de aglutinar los modos de hacer de producciones incluso anteriores a la aparición del término en el ámbito artístico. Inaugura así una complejización progresiva de la obra de arte, que comienza a establecer lazos con otras actividades humanas, y asume novedosas formas de interacción con el espectador, yuxtaponiendo elementos que involucran simultáneamente distintos canales sensoriales.

Su pertenencia a un territorio de fronteras y pasajes puede ser registrada desde múltiples aspectos: los múltiples géneros y medios que pone en cruce, los múltiples materiales y técnicas que utiliza, la integración del espectador como parte del hecho artístico, la multiplicidad de percepciones y puntos de vista que 
habilita. No obstante, su particularidad respecto de otras manifestaciones interdisciplinarias resulta de poner el acento en un matiz determinado: el estado performativo latente que subyace en ellas y la capacidad de propiciar la acción transformadora del entorno, que se pone en práctica al tener en cuenta desde la génesis de la obra el papel corporal del espectador.

La observación de una instalación tiene lugar en un espacio compartido con el espectador: los elementos que la constituyen establecen una interacción entre el espacio y quien lo vivencia, y en esta triangulación se hace posible una percepción estética de características singulares, de las que surgirá la dotación de sentido y por tanto, la propia obra. Por eso un análisis tradicional, aunque exhaustivo, resultaría insuficiente. En este marco resulta difícil establecer generalizaciones, por cuanto cada producción adquiere su sentido en el acontecimiento; por eso no bastará con definir un cúmulo de componentes materiales sino que siempre será preciso abordar la complejidad de la dinámica surgida en la torno a la experiencia del espectador.

Si consideramos que este tipo de obras es más una presentación de objetos que una representación, es porque el cuerpo del espectador (nuestro propio cuerpo) forma parte de lo que es percibido. Por eso todo lo que miramos aparece como elemento conformador de una nueva realidad: algo que trasciende el espacio, por lo que nos reconocemos como parte de un arte basado en la recepción, en esa experiencia individual e intransferible del espectador, que es condición para la existencia de la obra. De este modo, la idea de desmaterialización presente en el arte contemporáneo no se corresponde con una progresiva descorporeización del sujeto espectador, sino con un reforzamiento de sus capacidades perceptivas.

Así, y a pesar de su vínculo material con lo múltiple y lo reproductible, la obra adquiere un sentido unitario gracias a la presencia del espectador en unas coordenadas espacio-temporales específicas. Ese cuerpo constituido en núcleo se manifiesta como la entidad más determinante de las presentes (más que los mismos materiales de la instalación, que podrán ser variables). Por eso la obra será entonces concebida como una escena que el espectador habita, aunque siendo consciente de la condición de producción estética proyectada 
deliberadamente con el propósito de incorporarlo en un entorno de inmersión total.

En la experiencia descripta participan aspectos fenomenológicos: los datos y relaciones se perciben y se recuerdan; se deslizan en cada momento de la percepción, y se comparan con lo visto en un momento anterior; la recepción misma aparece sujeta a un devenir temporal. En este complejo juego de percepción, la obra se hace múltiple, en tanto responde a la experiencia individual de cada espectador. Claro está que el arte siempre es aprehendido desde la experiencia, pero este tipo de construcciones tienen la particularidad de poner énfasis en el carácter vivencial, en la introducción del espectador, y en la interacción que tiene lugar entre éste y el dispositivo.

Con la intervención de la dimensión temporal, con la multiplicación de objetos puestos a disposición, con la apropiación y transgresión de las fronteras arquitectónicas, las instalaciones consiguen desarrollar un carácter performativo y participativo aunque, como señaláramos, se encuentre en un estado latente. La participación del público es imprescindible para que la obra complete su sentido, y esto se verifica en las mismas estrategias que pone en escena, teniendo en cuenta el cuerpo del espectador.

En los casos que dimos en llamar inmersivos, el espectador asume una conciencia particular de su situación de desdoblamiento entre sujeto receptor y objeto de la representación. De esta manera, - y recreando los términos que Francisca Pérez Carreño adjudicara al arte minimal - "... no desaparece en la experiencia estética, sino que, como en un escenario, se ve viendo, no puede dejar de sentir que la obra está hecha para él, y que sus movimientos han sido previstos y son inevitables" (Pérez Carreño, 2003: 203). Resulta asimismo inevitable la consideración de la obra en relación a su propio cuerpo, por lo que se sumerge en una experiencia situada. De esta manera, desaparece la diferencia estricta entre interior y exterior, así como entre sujeto espectador y su función como componente constitutivo de la obra, en cuya situación se reconoce integrado.

En este punto queda manifiesto que la idea de instalación como dispositivo escénico supera ya la mera analogía de su apariencia formal con la de una 
escenografía deshabitada. Si, como señalábamos, estas obras establecen un sistema de coordenadas que predisponen al sujeto que se adentra en ellas, orientándolo a tomar una serie de actitudes posibles; y si la palabra escena, como la palabra instalación, refieren tanto a un lugar como a un tiempo determinado, que configuran en conjunto el marco para el desarrollo de un suceso, podemos afirmar que el carácter teatral que se advierte en aquellas es producto del exceso de sentido que generan los cuerpos presentes, y expuestos a la mirada del otro. Es esa presencia que incide sobre ella - aun a través de un mínimo gesto-, la que le otorga a la obra una cualidad teatral, que devela la relación que mantiene la instalación con la puesta en escena.

Siguiendo a Josu Larrañaga (2001) hemos señalado que las instalaciones funcionan como escenografías descentradas, no sólo porque construyen arquitecturas efímeras y las ponen a disposición de eventuales estrategias de uso e interacción, sino porque desplazan el punto de vista al interior de la obra, lo activan y multiplican en relación a un actuar encarnado por cada espectador, a través de una mediación enteramente corporal.

Así, el espacio y el tiempo vivenciales se convierten en espacio y tiempo artístico teatralizado, pero que no pretende transmutar en otro, sino reconfigurar en obra el aquí y ahora presente del espectador. En ese marco, el cuerpo del espectador opera materialmente sobre la ficción que se construye, en tanto todo movimiento, gesto o actitud aparecen formando parte de la construcción discursiva de la obra.

Y si bien no existe en esta intervención una intencionalidad enunciativa equiparable a la del actor - que responde tanto instintiva como técnicamente ante la certeza de ser mirado -, se hace evidente que la misma trasciende los alcances de la categoría de espectador participativo, de la que tanto ha hecho alarde el arte contemporáneo.

Por eso la asignación de la nueva categoría de espectador-actor pretende dar cuenta de la intervención de éste en la naturaleza ficcional de lo imaginario y de lo estético, que inaugura una nueva dimensión de la percepción y experimentación del mundo, a partir de la convergencia entre la materialidad de la obra, su propio cuerpo y el cuerpo del otro. 
En el campo de la Educación Artística, la posible instauración de la práctica de las instalaciones inmersivas en los ámbitos educativos se configura como un espacio posible donde enseñar y aprender a mirar y a mirarse, posibilitando al alumno sumergirse en una práctica situada, que lo invita a reflexionar no sólo sobre sus procesos de percepción sino también sobre sus propias vivencias.

Como señala Oscar Cornago

\author{
"(...) se trata de recuperar el cuerpo \\ como un modo de pensar y [de] estar \\ frente al otro" \\ (Cornago, 2008: 54)
}

La Plata, diciembre de 2014 


\section{Bibliografía citada y/o consultada}

Artaud, A. (1978) El teatro y su doble. Barcelona: Edhasa.

Bartís, R (2003) Cancha de niebla. Buenos Aires: Atuel.

Bellati, C (coord.) (2008). Arte contemporáneo argentino: artista por artista. Buenos Aires: Papers Editores.

Bishop, C. (2005). Installation Art: a critical history. Londres: Tate.

-------- (2006). "El arte de la instalación y su legado". En: Instalaciones y nuevos medios en la colección del IVAM. Espacio. Tiempo. Espectador. Valencia: Institut Valencià d'Art Modern (IVAM).

Bonet, E. (1995). "La instalación como hipermedio (una aproximación)". En Giannetti, C. (Ed.). Media Culture. Barcelona: L' Angelot.

Borja-Villel, M (ed) (2007) Un teatro sin teatro. Catálogo de la exposición organizada por el Museu d'Art Contemporani de Barcelona y coproducida por el Museu Coleccao Berardo - Arte Moderna e Contemporanea de Lisboa.

Brett, G. y otros. (2009). Cildo Meireles. Catálogo de exposición. Barcelona:

Museud 'ArtContemporani.

Breyer, G. (1968). Teatro, el ámbito escénico. Buenos Aires: Centro Editor de América Latina.

----------- (2005) La escena presente. Teoría y metodología del diseño escenográfico. Buenos Aires: Ediciones Infinito.

Brito, R. (1995). "Desvío para o vermelho, 1967-1984". En Cildo Mireles. Valencia: Alias.

Coulter-Smith, G (2009). Deconstruyendo las instalaciones. Madrid: Brumaria.

Ceballos, E. (1986) El actor sobre la escena. Diccionario de práctica teatral. México: Edit. Gaceta.

Cornago, O. (2009). "¿Qué es la teatralidad? Paradigmas estéticos de la modernidad". En Agenda Cultural Alma Mater № 158. Medellín: Universidad de Antioquia. - (2008). Éticas del cuerpo. Madrid: Fundamentos.

De Oliveira N., Petry M y Oxeley N (1994), The installation art. Londres: Thames and Hudson.

Dubatti, J. (comp) (2012). Introducción a los estudios teatrales. Buenos Aires: Atuel. ----------- (2008) "Teatro y cultura viviente". En Abalo, F (ed.). Arte y liminalidad. La Plata: Editorial de la Universidad Nacional de La Plata.

---------- (2005). Escritos sobre teatro I. Teatro y cultura viviente: poéticas, política e historicidad. Buenos Aires: Nueva generación.

Didi- Huberman, G (2010) Lo que vemos, lo que nos mira - $1^{\mathrm{a}}$ ed, $2^{\mathrm{a}}$ reimp, Buenos Aires, Manantial. 
Escobar, T. (2004). El arte fuera de sí. Asunción: CAV/Museo del Barro - FONDEC.

Foster, H (2001) El retorno de lo real. La vanguardia a finales de siglo. Madrid: Akal.

Fried, Michael (2004) Arte y objetualidad. Ensayos y reseñas. Madrid: La balsa de la Medusa.

Geczy, A - Genocchio, B (ed.) (2001). What is installation? An anthology of writings on Australian Installation Art. Sydney: Power Publications

Greenberg, C. (1979). Arte y cultura. Ensayos críticos. Barcelona, Gustavo Gili.

Grenier, C. (2009). Boltanski. Paris: Flammarion.

Grüner, E. (2004). "El conflicto de la(s) identidad(es) y el debate de la representación. La relación entre la historia del arte y la crisis de lo político en una teoría crítica de la cultura". La Puerta. Año 1. No 0. La Plata: FBA.

Guash, A (2000) El arte último del siglo XX. Del posminimalismo a lo multicultural. Madrid: Alianza Editorial.

Kabakov, I. (1995) Installations 1983-1995, París: Ed. Centre Georges Pompidou. ------ (2001). "La instalación total". En Larrañaga, J. Instalaciones. Guipúzcoa:

Nerea.

Kaye, N. (2000) Site-specific art. Performance, place and documentation. Londres: Routledge.

Krauss, R (1977) Pasajes de la escultura moderna. Madrid: Akal.

--------- (1985) La originalidad de la vanguardia y otros mitos modernos. Madrid: Alianza Forma (2002)

Kwon, M. (2002). One place after another. Site-specific art and locational identity. Massachusetts Institute of Technology.

Larrañaga, J. (2001). Instalaciones. Guipúzcoa: Nerea

---- (2008) "Trasferencia y trasparencia de la imagen artística". En Revista de Bellas Artes $N^{\circ}$ 6. Santa Cruz de Tenerife: Universidad de la Laguna.

Larratt-Smith, P - Morris, F. (2013). Yayoi Kusama. Obsesión Infinita. Catálogo de la muestra. Buenos Aires: MALBA. Fundación Constantini.

Marchán Fiz, S. (1994). La historia del cubo: Minimal Art y Fenomenología. Bilbao: Rekalde.

--------- (1990). Del arte objetual al arte de concepto. Epílogo sobre la sensibilidad posmoderna. Madrid: Akal.

Maderuelo, J. (1990). El espacio raptado. Interferencias entre arquitectura y escultura. Madrid: Mondadori.

----------- (2008). La idea de espacio en la arquitectura y el arte contemporáneos 1960-1989. Madrid: Akal.

Mayayo, P. (2002). Louise Bourgeois. Colección Arte Hoy. Guipúzcoa: Nerea. 
Merleau-Ponty, M. (1975). Fenomenología de la percepción. Barcelona: Ediciones Península.

Oliveras, E. (2000). La levedad del límite. Buenos Aires: Fundación Pettoruti.

---------- (1994). "La instalación, arte de la presencia" en Espacio de Arte, № 2. Rosario.

Pavis, P. (2000). El análisis de los espectáculos. Teatro, mimo, danza, cine. Barcelona: Paidós Comunicación.

-------- (1980). Diccionario del teatro. Dramaturgia, estética, semilogía. Barcelona: Paidós Comunicación.

Pérez Carreño, F. (2003). Arte minimal. Objeto y sentido. Madrid: La balsa de la Medusa.

Rolnik, S. (2008). "Desvío hacia lo innombrable". En Brett, G. (Ed.). Cildo Meireles. Catálogo de exposición. Barcelona: Museu d'Art Contemporani.

Sánchez, J. (2009). "Teatralidad y cultura visual". En Revista 0000. Madrid: Museo Nacional Centro de Arte Reina Sofía.

Sánchez, J. - Prieto, Z. (2010). Teatro. Itinerarios por la Colección. Madrid: Museo Nacional Centro de Arte Reina Sofía..

Sánchez Argilés, M. (2009). La instalación en España, 1970-2000, Madrid: Alianza.

- (2004). "Los límites de la instalación". En Ramírez, JA y Carrillo, J (eds) (2004) Tendencias del arte, arte de tendencias a principio del siglo XXI. Madrid: Ensayos Arte Cátedra.

Tejeda, I. (2006). Instalaciones y nuevos medios en la colección del IVAM. Espacio. Tiempo. Espectador. "Pasajes de espacio, tiempo y espectador: instalaciones, nuevos medios y piezas hibridas en la colección del IVAM". Valencia: Institut Valencià d'Art Modern.

Tejeda Martín, I. (2006). El montaje expositivo como traducción. Fidelidades, traiciones y hallazgos en el arte contemporáneo desde los años 70. Madrid: Trama Editorial y Fundación de Arte y Derecho.

Watkins, J. (1997). "Installation is everything and everything is Installation", en AAVV, You are here. Re-siting installations. Catálogo de exposición, Royal College of Art, Londres.

Weschler, D. (2012). Boltanski Buenos Aires. [Catálogo de la muestra]. Buenos Aires: UNTREF.

Zamudio-Taylor, V. (2006). "Historia y estrategias conceptuales". En Hatje Cantz Verlang (ed.). Seduções: Valeska Soares, Cildo Meirles, Ernesto Neto. Zürich: Daros Latinoamérica AG.

\section{Fuentes de Internet}

Aninat, T. (2004). En Memoria. Portal de Tesis electrónicas de la Universidad Nacional de Chile [en línea]. Consultado el 28 de octubre de 2013 en <www.cybertesis.cl/tesis/uchile/2004/aninat_t/sources/aninat_t.pdf>. 
Ayala, G. (2013) "Lo siniestro en el minimalismo" [en línea]. Consultado el 16 de agosto de 2013 en <http://culturacolectiva.com/lo-siniestro-en-el-minimalismo/>.

Brea, JL. "Ornamento y utopía. Evoluciones de la escultura en los años 80 y 90". [en línea]. Consultado el 8 de marzo de 2014 en $<$ http://issuu.com/nirbhe/docs/brea ornamento y utopia $>$.

Buján, F. (2008). "Modalidades vinculares en el dispositivo interactivo de formación mediatizada", [En línea] Consultado el 28 de julio de 2012 en

<http://www.unam.edu.ar/2008/educacion/trabajos/Eje\%203/313\%20-bujan.pdf.>

Cortés Santander, J. (2005). Las prácticas espaciales como posibilidad de lo material incorpóreo. Colección de Tesis digitales Universidad de las Américas. Puebla [en línea]. Consultado el 29 de octubre de 2013 en <http://catarina.udlap.mx/u_dl_a/tales/documentos/lap/cortes_s_jl/>.

Debona, S. (2003). "Los espacios inmersivos (o en busca del paraíso perdido)". En Didascalia. Revista electrónica de teoría y práctica teatral. № 2. [en línea]. Consultado el 16 de marzo de 2006 en <http://andamio.freeservers.com/dida/num-dos/dabona.pdf>.

De Duve, T. (2009). Arte Efímero. En Sucari Jabbaz, G. El documental expandido: pantalla y espacio. Espacio Tesis documentales en Red [en línea]. Consultado el 28 de octubre de 2013 en <http://www.tdx.cat/bitstream/handle/10803/52895/GJSC TESIS.pdf?sequence $=1>$.

Groys, B. (2008). "La topología del arte contemporáneo". Centro Cultural Rector Ricardo Rojas [en línea]. Consultado el 28 de octubre de 2013 en

$<$ www.rojas.uba.ar/lipac/biblioteca/groys.pdf $>$.

Kabakov, I.; Groys, B. (1990). "De las instalaciones, un diálogo entre Ilya Kabakov y Boris Groys". Lugar a dudas [en línea]. Consultado el 28 de octubre de 2013 en $<$ www.lugaradudas.org/pdf/cuartilla5.pdf $>$.

La argentinidad... al palo (2006). "El mundo fantástico de Renata Schussheim en el Bellas Artes". En La argentinidad... al palo. Blog de política, ciencia y cultura [en línea]. Consultado el 18 de marzo de 2009 en <http://luchadores.wordpress.com/2006/10/03/el-mundo-fantastico-de-renataschussheim-en-el-bellas-artes/>.

Lebenglik, F. (2012). "Migrantes en clave Fantasmagórica", en Página 12, suplemento de Cultura y Espectáculo [en línea]. Consultado el 17 de noviembre de 2012 <http://www.pagina12.com.ar/diario/suplementos/espectaculos/6-26799-2012-10-

23.html>.

Martín, D. (2010). "Cuerpo en acto: el pensamiento de la actuación", en Afuera, Estudios de Crítica Cultural $N^{\circ} 11$ [en línea]. Consultado el 4 de octubre de 2013 <http://www.revistaafuera.com/articulo.php?id=193\&nro=11>.

Mateo, A. (2006). "La epifanía de Renata". En Revista Psique Navegante No 75 [en línea]. Consultado el 13 de diciembre de 2013 en <http://psychenavegante.net/index.php?option=com_content\&view=article\&id=1118:laepifania-de-renata\&catid=178: cultura $>$. 
Meunier, JP. (1999) "Dispositivo y teorías de la comunicación: dos conceptos en relación de codeterminación". [En línea] Consultado el 20 de abril de 2012 en $<$ www.perio.unlp.edu.ar/sites/.../comunicacion_y_cultura_cat_i_0.pdf>

Perán, M. (2003) "Instaladores en el museo (la instalación como dispositivo expositivo y como episodio en la historia institucional del arte)" [en línea]. Consultado el 23 de marzo de 2012 en <http://www.martiperan.net/print.php>.

Pérez Bergliaffa, M. (2012). "El artista y sus obras con fantasmas. Entrevista a Christian Boltanski". Revista de cultura $\tilde{N}$ [en línea]. Consultado el 28 de octubre de 2013 en <http://www.revistaenie.clarin.com/arte/Christian-Boltanski-Buenos-

Aires_0_789521222.html>.

Rodríguez Cunnil, I. (1999). Multiplicidad y fragmentariedad en el arte contemporáneo a través de un análisis de instalaciones y videoinstalaciones. Biblioteca Virtual Miguel de Cervantes [en línea]. Consultado el 2 de enero de 2010 en <http://www.cervantesvirtual.com/nd/ark:/59851/bmcw0908>.

Russo, S. (2012). "Memorias de/con fantasmas. De inmigraciones, museos, memoria y Nación". LaTecl@ Eñe. Revista Digital de Cultura y Política [en línea]. Consultado el 28 de octubre de 2013 en

<http://lateclaene.blogspot.com.ar/2012/10/sociedad-y-artememorias-decon-

fantasmas.html>.

Sánchez Argilés, M. (2009). "La instalación, cómo y por qué. Claves y pistas para entender su desarrollo en España". El Cultural [en línea]. Consultado el 28 de octubre de 2013

en <http://www.elcultural.es/version_papel/ARTE/25543/La_instalacion_como_y_por_que>.

Schussheim, R. (2006, 1 de octubre). "Esculturas, instalaciones y dibujos en una retrospectiva de Renata Schussheim". En Diario HOY Cultura, edición del 1 de octubre de 2006. [en línea]. Consultado el 8 de agosto de 2008 en <http://pdf.diariohoy.net/2006/10/01/pdf/s04-sup.pdf>.

Viña, E. (2914). "El último que apague la luz" en Radar, Suplemento de Cultura de Página 12 [en línea]. Consultado el 11 de septiembre de 2014 <http://www.pagina12.com.ar/diario/suplementos/radar/9-9907-2014-07-30.html>. 